UNIVERSIDADE DE SÃO PAULO

FACULDADE DE ECONOMIA, ADMINISTRAÇÃO E CONTABILIDADE DEPARTAMENTO DE ECONOMIA PROGRAMA DE PÓS-GRADUAÇÃO EM ECONOMIA

ADMINISTRAÇÃO DA DÍVIDA PÚBLICA: UM ESTUDO PARA O CASO BRASILEIRO

Guilherme Tinoco de Lima Horta

Orientador: Prof. Dr. Siegfried Bender

SÃO PAULO 
Prof. Dr. João Grandino Rodas

Reitor da Universidade de São Paulo

Prof. Dr. Reinaldo Guerreiro

Diretor da Faculdade de Economia, Administração e Contabilidade

Prof. Dr. Denisard Cneio de Oliveira Alves

Chefe do Departamento de Economia

Prof. Dr. Dante Mendes Aldrighi

Coordenador do Programa de Pós-Graduação em Economia 
GUILHERME TINOCO DE LIMA HORTA

\section{ADMINISTRAÇÃO DA DÍVIDA PÚBLICA: UM ESTUDO PARA O CASO BRASILEIRO}

Dissertação apresentada ao Departamento de Economia da Faculdade de Economia, Administração e Contabilidade da Universidade de São Paulo como requisito para a obtenção do título de Mestre em Economia.

Orientador: Prof. Dr. Siegfried Bender

\section{SÃO PAULO}




\section{FICHA CATALOGRÁFICA}

\section{Elaborada pela Seção de Processamento Técnico do SBD/FEA/USP}

Horta, Guilherme Tinoco de Lima

Administração da dívida pública: um estudo para o caso brasileiro /

Guilherme Tinoco de Lima Horta. -- São Paulo, 2011. $105 \mathrm{p}$.

Dissertação (Mestrado) - Universidade de São Paulo, 2011.

Orientador: Siegfried Bender.

1. Dívida pública 2. Política fiscal 3. Títulos públicos I. Universidade de São Paulo. Faculdade de Economia, Administração e Contabilidade II. Título.

CDD -336.34 


\section{Aos meus pais.}


Em primeiro lugar, gostaria de agradecer ao meu orientador, Prof. Siegfried Bender, pela atenção, paciência e sugestões dadas ao longo de todo esse período. Aos Professores Fabiana Rocha e Mauro Rodrigues, membros da mini-banca e banca de qualificação, também agradeço pela colaboração para a melhoria do trabalho, através de críticas e sugestões dadas. Aos Professores que me deram aula: Chiappin, Gabriel Madeira, Fernando Botelho, Denisard, Mauro, Vera Fava, Pedro Duarte, Carlos Eduardo, Naércio e Siegfried Bender. Aos Professores Basília e Marcos Rangel, pela oportunidade de ser monitor em suas respectivas matérias para a graduação, Economia Brasileira e Econometria I. Ainda agradeço à Cida e aos demais professores e funcionários da FEAUSP, que fazem desta faculdade um lugar tão agradável para a produção acadêmica.

Aos colegas da turma de mestrado de 2008, bem como aos colegas das outras turmas de mestrado e doutorado. Em especial à Barufi, Alex, Gasperini, Westin, Carla, Grimaldi, Danilo, Cegonha, Duda, Genta, Attuy, Penin, Gustavo, Henrique, Igor, Jaqueline, Joço, Leandro, Lídia, Luiz Felipe, Meloni, Maracajaro, Marco, Mirela, Paula, Gouvêa, Crouch, Raquel, Renan, Ricardo Leal, Sabbadini, Sérgio, Sílvio, Kang, Tiagão e Vivi. Os melhores momentos em São Paulo sem dúvida foram passados ao lado deles.

Aos colegas da república do Butatã, Gustavo, Henrique, Gouvêa e Kang, pelos grandes momentos vividos. Ainda agradeço ao Bruno Westin e Raphael Gouvêa, por terem me tirado tantas dúvidas em relação à FEA após a prova da Anpec. Aos colegas e amigos que leram versões anteriores do trabalho e/ou ajudaram com alguma questão específica, como Fernando Genta, Gustavo Rechdan, Henrique, Marcelo Tinoco, Pedro Duarte, Raphael Gouvêa, Ricardo Sabbadini e Tiago Toledo. Ainda aos técnicos do Tesouro Nacional que me ajudaram com algum material bibliográfico.

À USP, à FEA, aos demais amigos e ao Fut-Fea. O ambiente acadêmico da USP sem dúvidas deixará muitas saudades. Aos amigos e familiares, incluindo professores da UFMG. Ao meu irmão Bernardo e aos meus avós, pelo apoio e carinho. Aos meus colegas do BNDES, pela compreensão e apoio para que eu concluísse o trabalho.

Agradeço especialmente aos meus pais, pelo amor e apoio incondicional para que eu pudesse alcançar todos os meus objetivos. Os valores relacionados à educação e a uma sólida formação acadêmica, transmitidos por eles, foram fundamentais para o alcance desta meta.

À Aninha, pelo amor, carinho e compreensão pela ausência em vários momentos.

Por fim, agradeço ao apoio financeiro do IPEA, que tornou possível a elaboração desta dissertação. 


\section{RESUMO}

Esta dissertação busca estudar estratégias eficientes para a gestão da dívida pública brasileira. Utiliza-se uma metodologia recorrente na literatura, que consiste em estimar e simular a economia através de um modelo estrutural Novo-Keynesiano e, em seguida, verificar qual o comportamento da relação Dívida/PIB para vários tipos de composição da dívida. Trabalhase, portanto, com uma análise de risco e retorno para diversas carteiras da dívida, em uma abordagem focada na fronteira eficiente. Duas classes de modelos são utilizadas: backwardlooking (BL) e o forward-looking (FL). A estimação foi realizada por Mínimos Quadrados Ordinários e a amostra utilizada foi trimestral, variando do primeiro trimestre de 1999 ao terceiro trimestre de 2010. Os resultados principais indicaram que, quando se trabalha com um modelo FL, as carteiras eficientes são compostas quase que exclusivamente por títulos indexados à inflação. Por outro lado, quando se utiliza um modelo BL, os resultados indicam que as carteiras eficientes são híbridas, sendo compostas por títulos de diferentes indexadores, incluindo grande parte de títulos indexados à inflação. 


\begin{abstract}
This dissertation studies efficient strategies for Brazilian public debt management. We use a common methodology in the literature, as we estimate and simulate the economy through a New-Keynesian structural model. Then we verify the Public Debt/GDP indicator behavior, considering different debt compositions. We utilize a risk/return analysis for each debt composition in an efficient frontier approach. Two types of models are specified: backwardlooking (BL) and forward-looking (FL). We estimate the model by Ordinary Least Squares using a quarterly sample, available from the first quarter of 1999 to the third quarter of 2010. The main results show that when the economy has forward-looking features, efficient compositions are formed almost exclusively by inflation-linked bonds. In the other hand, when we utilize a backward-looking specification, results indicate that efficient compositions are formed by different types of bonds, including a large part of inflation-linked bonds.
\end{abstract}




\section{SUMÁRIO}

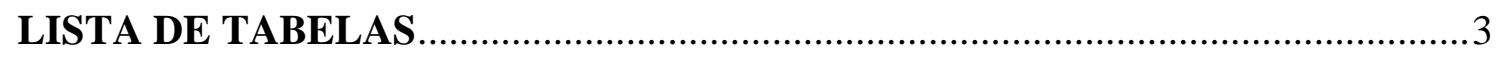

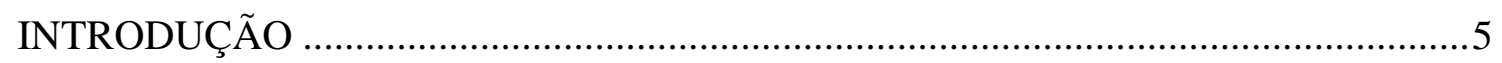

1. FUNDAMENTAÇÕES TEÓRICAS ................................................................... 9

1.1 Endividamento Público e a coordenação das políticas monetária e fiscal ...............9

1.2 Aspectos fundamentais da gestão da Dívida Pública............................................. 10

1.3 A Dívida Pública no Brasil: conceitos e gestão .................................................. 15

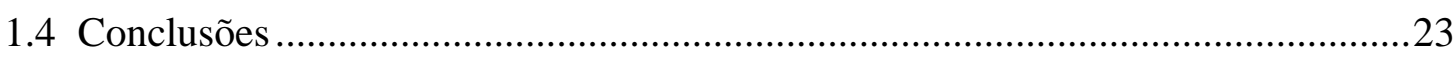

2. A TRAJETÓRIA RECENTE DOS INDICADORES DA DÍVIDA PÚBLICA

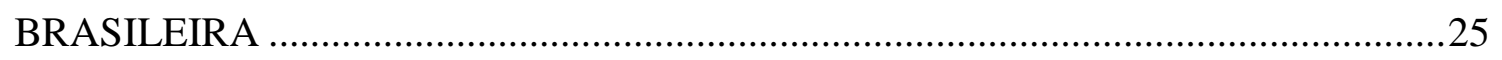

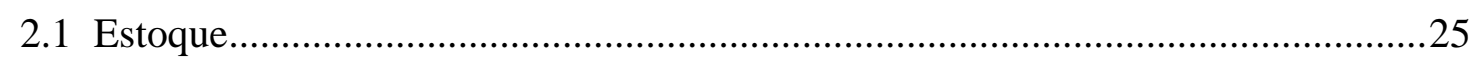

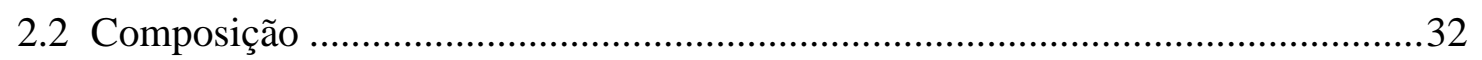

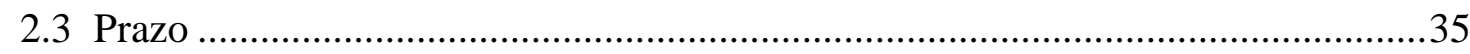

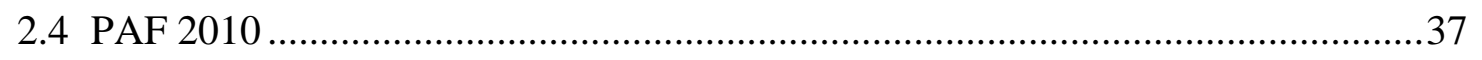

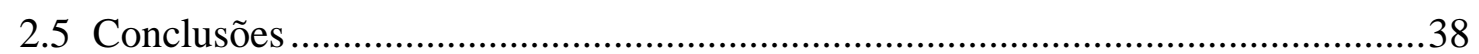

3. BUSCANDO UMA ESTRATÉGIA PARA A GESTÃO DA DÍVIDA PÚBLICA41

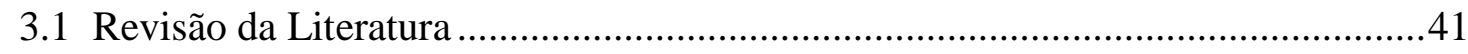

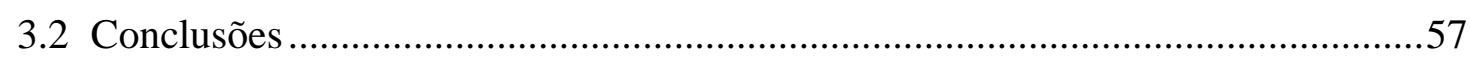

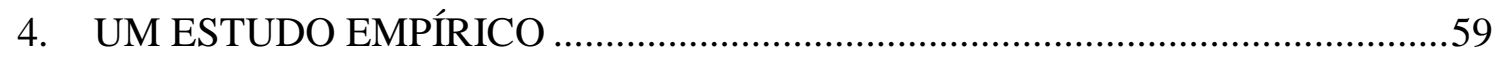

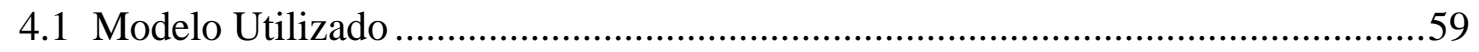

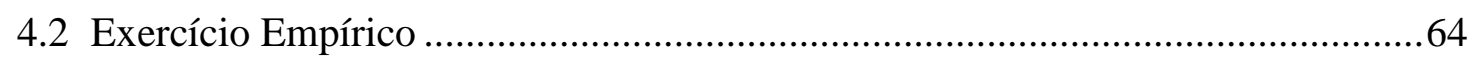

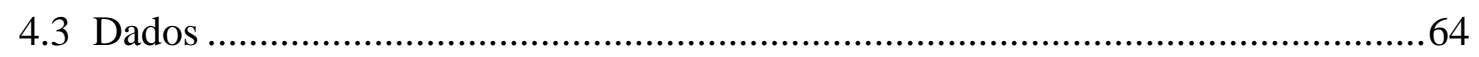

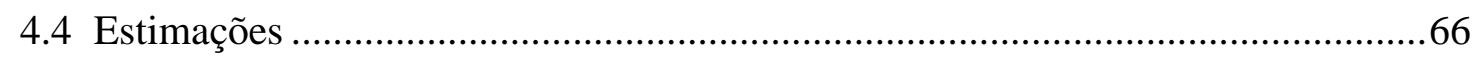

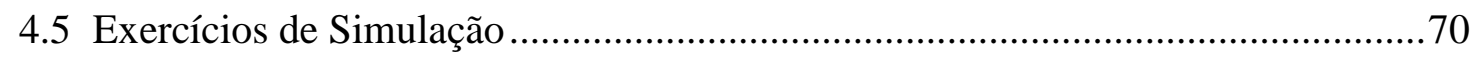

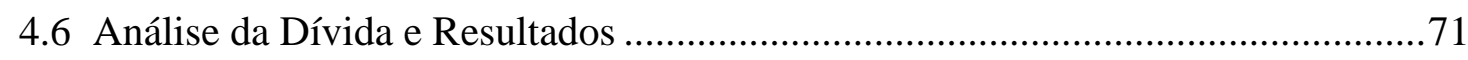

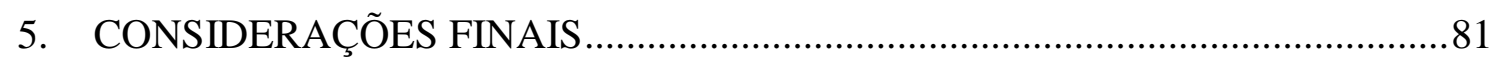

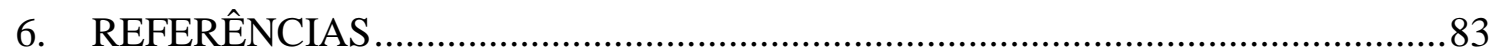

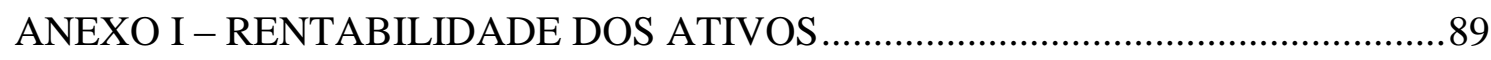

ANEXO II - TESTES DE RAIZ UNITÁRIA ............................................................

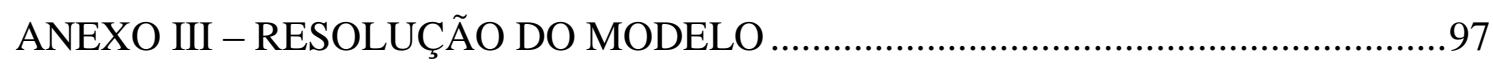

ANEXO IV - GRÁFICOS DE MARKOWITZ PARA OS 4 MODELOS.....................99 


\section{LISTA DE TABELAS}

Tabela 1 - Dívida Líquida do Setor Público - Brasil .............................................................. 18

Tabela 2 - Crescimento do PIB e NFSP (primário) - Brasil - 1991 a 2008 ............................ 27

Tabela 3 - Evolução da Dívida Líquida - Fatores condicionantes - 2002 a 2009 .................. 30

Tabela 4 - Evolução da Dívida Pública - Diferentes conceitos - 1997 a 2010........................ 32

Tabela 5 - Metas da Dívida Pública Federal para 2010 ......................................................... 38

Tabela 6 - Resultados das estimativas Modelo Backward-Looking ........................................ 67

Tabela 7 - Resultados das estimativas Modelo Forward-Looking ......................................... 68

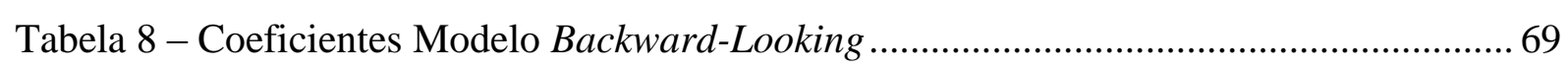

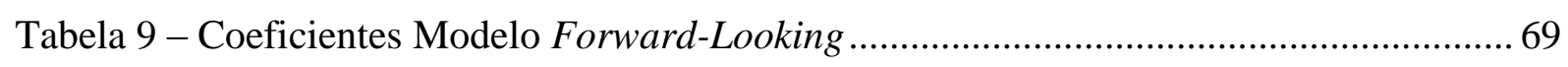

Tabela 10 - Relação dos modelos utilizados na Simulação .................................................. 70

Tabela 11 - Cenários econômicos resultantes da simulação para os 4 Modelos Utilizados.... 72

Tabela 12 - Resultados da Simulação Modelo 1 ................................................................... 73

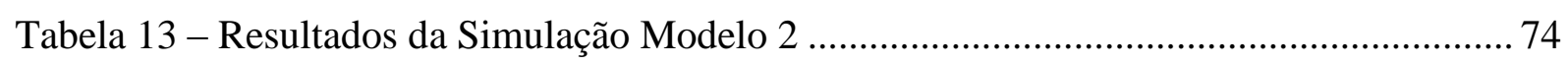

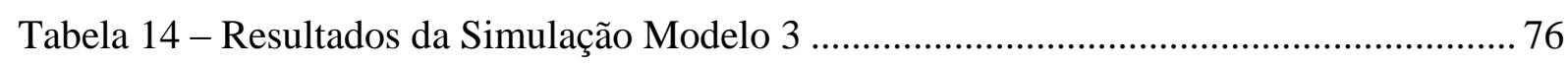

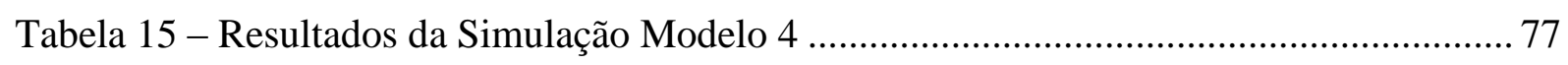

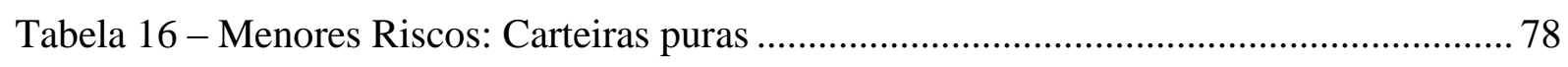

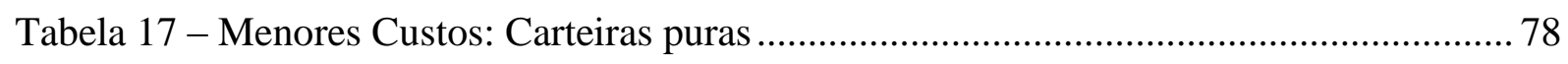

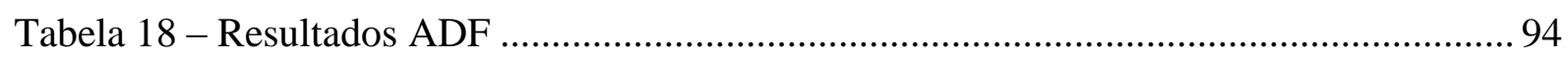

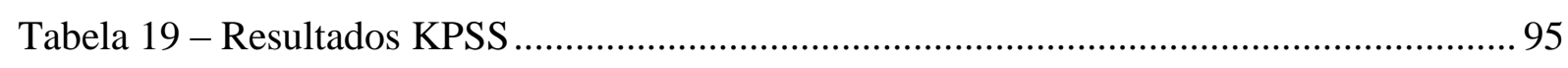




\section{INTRODUÇÃO}

A dívida pública é um recurso de uso muito antigo na história das finanças públicas. Inicialmente, era uma alternativa usada para equilibrar as finanças do Estado em situações emergenciais, tais como as guerras. Nessas ocasiões, a contratação dos empréstimos era geralmente feita juntos aos ricos comerciantes da nação. Com o passar dos séculos, a partir da formação dos Estados modernos, da dissociação entre o patrimônio do monarca e o Tesouro Público e, posteriormente, do desenvolvimento do sistema bancário, o instrumento da dívida passou a ser mais utilizado para financiar as despesas dos governos, tanto as emergenciais como também as correntes. Essa evolução continuou em sua tendência expansiva até o século XX, principalmente após a Primeira Guerra Mundial, quando a emissão de papel moeda inconversível e títulos públicos ganhou maior importância. Deste modo, a contratação de dívida assumiu um caráter menos esporádico e o recurso da dívida pública ganhou uma importância ainda maior dentro das economias modernas.

Durante as décadas de 70 e 80 , o tema da dívida pública conquistou seu espaço dentro do debate econômico. Depois de uma fase dourada do capitalismo, que combinou crescimento acelerado, inflação controlada e ganhos de produtividade, as maiores economias do mundo chegaram à década de 70 combinando baixo crescimento e alta inflação. Diante desse cenário, a dívida pública de diversos países assumiu valores bastante elevados, despertando, pela primeira vez, dúvidas quanto a sua sustentabilidade ${ }^{1}$ (HAMILTON E FLAVIN, 1986; TREHAN E WALSH, 1988; WILCOX, 1989; BOHN, 1995, dentre outros).

Como forma de ilustração desse ponto, Dornbusch e Draghi (1990) mostram a evolução da razão dívida/PIB para países selecionados entre 1981 e 1988. Somente dois países da amostra² não tiveram a sua razão Dívida/PIB aumentada. Para o grupo Europe-10 ${ }^{3}$, por exemplo, esse índice subiu quase $50 \%$ no período, passando de 40,6\% para 58,7\%. Portanto, de maneira geral, percebeu-se um salto expressivo na dívida/PIB dos países, que pode ser atribuído às (i)

\footnotetext{
${ }^{1}$ Além do alto nível da relação Dívida/PIB, vale destacar que uma parcela cada vez maior das receitas governamentais deveriam ser destinadas ao pagamento dos juros da dívida, sendo que choques inesperados nos juros ou crescimento, poderiam colocar a razão dívida/PIB em um caminho explosivo. Juntos, esses dois efeitos ajudaram a despertar esses questionamentos a respeito da capacidade de pagamento.

${ }^{2}$ A amostra foi composta por Alemanha, Bélgica, Dinamarca, Espanha, EUA, Grécia, Holanda, Itália, Japão, Luxemburgo, Portugal e Reino Unido, sendo que os únicos países que não tiveram a sua Dívida/PIB aumentada foram Luxemburgo e Reino Unido.

${ }^{3}$ São 10 países da Europa, porém, o autor não especificou quais fariam parte do índice.
} 
altas taxas de juros praticadas no período, (ii) ao baixo crescimento econômico e (iii) aos déficits primários observados (DORNBUSCH E DRAGHI, 1990).

Portanto, para manter a dívida sob controle, os países tiveram que realizar ajustes orçamentários, basicamente pelo corte de gastos. Além disso, com o serviço da dívida crescente, ganhou destaque o gerenciamento técnico da dívida pública, com o objetivo de financiá-la com os menores custos e risco, evitando que choques inesperados causassem saltos na dívida. Conforme destacado por Missale (1999), "As the debt ratio rises, the effects of alternative funding policies become as important as the effects of budget deficits". Desta maneira, a administração da dívida pública entrava definitivamente na agenda da gestão macroeconômica dos países.

Para os países em desenvolvimento, entretanto, apesar de importante, a gestão da dívida sempre foi uma tarefa difícil. A instabilidade macroeconômica acabava condicionando a escolha do setor privado em títulos públicos. Nesse sentido, o prêmio de risco para determinados prazos e tipos de títulos inviabilizavam a sua emissão, limitando as estratégias possíveis a serem adotadas pelo Tesouro.

No Brasil, portanto, a questão fiscal da administração da composição e maturidade da dívida pública brasileira não esteve, tradicionalmente, no topo das prioridades do governo, em virtude do longo período de inflação descontrolada, incertezas políticas, frustrados planos de estabilização na economia brasileira e calotes e renegociações de dívida. Na maioria das vezes, o foco acabava sendo o curto prazo.

Tal situação começou a mudar em 1999, quando, após uma crise cambial, o governo brasileiro adotou o regime das metas de inflação, marcando o início de uma nova etapa do Plano Real. Assim, a partir desse momento, a política macroeconômica do país passou a ser sustentada por um tripé formado pelas metas de inflação, superávits primários e câmbio flutuante.

Ciente de que a credibilidade é um dos pressupostos centrais para o alcance de melhores resultados com esse desenho institucional, o governo começou a colocar em prática algumas medidas, tanto na política fiscal como na política monetária, que buscaram elevar os níveis de transparência e de comunicação. Uma delas foi justamente a reestruturação da área 
responsável pela gestão da dívida pública na Secretaria do Tesouro Nacional. Dentre outras medidas, pelo lado fiscal, podem ser destacadas a fixação de metas para o superávit primário, a aprovação da Lei de Responsabilidade Fiscal (LRF), a reestruturação das dívidas estaduais e municipais e a elaboração do Plano de Financiamento Anual da dívida pública (PAF), documento no qual o Tesouro comunicaria ao público os seus objetivos e ações relacionados à gestão da dívida pública.

Nesse sentido, no período mais recente, principalmente no pós-1999, a partir desta melhora institucional e de um quadro macroeconômico de maior estabilidade, abriu-se espaço para um estudo mais aprofundado acerca da gestão da dívida pública brasileira. No atual contexto, o mercado estaria mais receptivo em relação a uma gama maior de tipos e prazos de títulos públicos, sem exigir prêmios de risco proibitivos, ampliando os graus de liberdade para que o Tesouro efetivamente administrasse a dívida e tornando possível a formulação de estratégias que priorizassem o longo prazo.

Desta maneira, esta dissertação busca estudar estratégias eficientes para a gestão da dívida pública brasileira. Para alcançar esse objetivo, no primeiro capítulo, são apresentados os aspectos fundamentais da administração da dívida pública, destacando a relevância do tema e as principais questões com que se deparam os gestores da dívida. Neste capítulo também são definidos conceitos de dívida pública para o Brasil, como os de DLSP (Dívida Líquida do Setor Público) e DPF (Dívida Pública Federal), além dos principais ativos e passivos financeiros do governo que determinam a evolução da DLSP. Ainda será objetivo deste capítulo apresentar o desenho institucional existente para a gestão da dívida pública no Brasil. Acredita-se que a formalização de todos esses conceitos será fundamental para o entendimento dos capítulos posteriores. No Capítulo 2, busca-se analisar a trajetória da dívida pública brasileira a partir dos anos 90, destacando os aspectos de sua gestão, como principais indexadores, prazos e a evolução de seu estoque. São destacadas as mudanças recentes, como a alteração da composição da dívida em favor de títulos prefixados e indexados a preços, a redução quase completa da dívida externa e o alongamento dos prazos. Essa evolução torna possível, no atual momento, uma reflexão maior sobre as estratégias a serem adotadas, já que uma série de restrições ao gerenciamento da dívida já não existem mais. No terceiro capítulo, são apresentados os principais trabalhos aplicados que buscaram chegar a um benchmark para 
a dívida pública brasileira ${ }^{4}$. No quarto capítulo, seguindo a literatura discutida no capítulo anterior, realiza-se um estudo empírico que tem como objetivo estudar estratégias eficientes para a gestão da dívida pública brasileira com o foco na minimização da volatilidade orçamentária, isto é, atuando dentro do tradeoff entre risco e custo esperado. Utiliza-se uma metodologia recorrente na literatura, que consiste em estimar e simular a economia através de um modelo estrutural Novo-Keynesiano e, em seguida, verificar qual o comportamento da relação Dívida/PIB para vários tipos de composição da dívida. Busca-se trabalhar com modelos diferentes, que captem características distintas da economia, como a formação das expectativas (backward-looking ou forward-looking). Para finalizar, no último capítulo são apresentadas as considerações finais desta dissertação.

\footnotetext{
${ }^{4}$ Um benchmark representa a composição da dívida que o governo gostaria de ter no médio e longo prazo e serve, portanto, como um guia para as estratégias de financiamento no curto prazo.
} 


\section{FUNDAMENTAÇÕES TEÓRICAS}

\subsection{Endividamento Público e a coordenação das políticas monetária e fiscal}

A administração da dívida pública é um importante instrumento de política econômica, principalmente pela sua interdependência com a condução das políticas monetária e físcal. Ao analisar o papel da dívida pública no desempenho macroeconômico, mais fica evidente a necessidade da coordenação entre as políticas monetária e fiscal. Juros altos implicam em maiores serviços da dívida já acumulada (principalmente se grande parte da dívida for indexada a taxa de juros), fazendo com que uma política monetária restritiva possa gerar grandes gastos do governo. Se a política fiscal for expansiva, por exemplo, tal combinação pode desencadear uma crise fiscal, provocando o crescimento da inflação.

Em um desenho institucional tradicional, a autoridade fiscal (AF) tem como objetivo principal a administração das finanças do governo de maneira ótima, procurando minimizar o custo do financiamento da dívida pública no longo prazo. Analogamente, a autoridade monetária (AM) busca manter a estabilidade de preços, utilizando, como um de seus principais instrumentos, a manipulação das taxas de juros. Dessa maneira, em um contexto onde a AM age independentemente da AF, a decisão unilateral de uma delas pode dificultar o alcance dos objetivos da outra, como no exemplo anterior.

Em um dos trabalhos clássicos nessa área, Sargent e Wallace (1981) apresentam justamente essa idéia. Dados déficits e um limite ao endividamento, uma política de controle da inflação gera inflação futura, porque agentes antecipam que o governo terá que emitir mais moeda no futuro para financiar a dívida acumulada no período que tentou combater a inflação. Assim, pelo canal das expectativas, os agentes acabariam elevando a inflação corrente, o que foi chamado pelos autores de a "desagradável aritmética monetarista".

King (1995) também estudou a interação entre as políticas macroeconômicas. A partir de seu modelo, percebeu que, quando a AM não tem uma sólida credibilidade, para controlar a inflação, acaba tendo que estabelecer uma taxa de juros maior. Assim, enquanto a credibilidade vai sendo construída, exige-se um esforço fiscal maior para o pagamento dos juros. Fazendo um contraponto à idéia de Sargent e Wallace (1981), chamou o fenômeno de “desagradável aritmética fiscal". 
Nesse mesmo sentido, Mendonça (2003) aponta que a coordenação entre as políticas tendem a produzir resultados melhores do que a não coordenação. Seriam duas razões principais: ao reduzir a probabilidade de conflito de interesses entre a $\mathrm{AF}$ e a $\mathrm{AM}$ e ao reduzir a incerteza dos agentes econômicos, aumentando a credibilidade.

Blanchard (2004) analisa os efeitos da política monetária em condições de alto endividamento público. Em situações normais, quando a AM eleva os juros, ocorre um aumento da demanda pelos títulos, o que acarreta em valorização cambial. Quando a dívida já é muito alta, no entanto, a elevação dos juros pode sinalizar um maior risco de default, aumentando a percepção de risco dos agentes. Assim, pode ocorrer uma queda na demanda pelos títulos do governo e uma saída de capitais, causando a depreciação do câmbio. Novamente, ter-se-ia a situação de dominância fiscal.

Procurou-se, nesta seção, fazer uma breve introdução sobre a importância da coordenação das políticas monetária e fiscal. Como a dívida pública é um elo muito forte entre essas políticas, o administrador da dívida e a sua estratégia ótima devem levar em conta os impactos que suas ações podem ter em um contexto mais amplo. Na seção seguinte, buscar-se-á apresentar os fundamentos da gestão ótima da dívida pública.

\subsection{Aspectos fundamentais da gestão da Dívida Pública}

$\mathrm{Na}$ literatura, geralmente considera-se que a dívida pública do governo é basicamente financiada através de quatro tipos de títulos: (i) prefixados, (ii) indexados ao câmbio, (iii) indexados à taxa de juros (iv) indexados à inflação.

O título prefixado é aquele com o menor risco para o governo, pois este já sabe o quanto irá pagar no seu vencimento. No entanto, por trazer mais riscos ao investidor, apresenta um custo maior e um prazo menor. Ele possui a vantagem (importância) adicional de auxiliar na construção da curva de juros do país. Os títulos indexados pelo câmbio, por sua vez, trazem o risco da desvalorização cambial para o governo. No entanto, são mais fáceis de alongar (em termos de custo) e permitem a oferta de um hedge cambial, diminuindo a procura do setor privado por dólares. Os títulos indexados pela taxa de juros têm custos menores e também um prazo maior; por outro lado, apresentam um risco maior para o governo e aumentam a contaminação da política fiscal pela política monetária. Por fim, os títulos indexados por 
índices de preços também permitem mais facilmente um alongamento do prazo, além de sinalizar um compromisso do governo com baixa inflação. Carregam, no entanto, os riscos de inflação alta, o que poderia acarretar em maiores despesas para o Tesouro no pagamento de juros.

Assim, a grande questão para o governo é identificar qual seria a composição ótima para a sua dívida pública, respeitando as restrições impostas pelas condições estruturais e conjunturais específicas a cada país. Para entender a importância da questão, Goldfajn e Paula (1999) sugerem partir de algumas hipóteses sob as quais a questão da composição da dívida seria um tema irrelevante. A partir do relaxamento dessas hipóteses, a composição da dívida pública se tornaria um instrumento de melhora do bem-estar social e, portanto, uma questão relevante em termos de política. Assim, os autores estabelecem essas três hipóteses que caracterizariam o paradigma inicial: (i) Equivalência Ricardiana, (ii) Inexistência de distorções tributárias e (iii) Existência de mercados completos e informação simétrica.

A primeira hipótese se baseia no trabalho de Barro (1974), que estabeleceu que, sob a hipótese da equivalência ricardiana, a escolha entre impostos e dívida pública como formas de financiamento dos gastos do governo seria neutra em relação ao bem-estar social. Mesmo a composição da dívida não traria nenhum ganho em termos do bem-estar social. Wallace (1981) estende, também no contexto da equivalência ricardiana, o teorema de ModiglianiMiller (1958) ${ }^{5}$ para operações de mercado aberto mostrando que as escolhas de consumo e o nível geral de preços é independente da composição de portfólio do Tesouro e do Banco Central.

A segunda hipótese estabelece que, sem a presença de distorções tributárias, não seria relevante estudar diferentes tipos de taxação (trabalho ou capital), ou diferentes prazos de pagamento. No entanto, quando esta hipótese é relaxada, ganha-se importância a discussão sobre o timing dos impostos, bem como a escolha entre diferentes categorias de tributos. Nesse sentido, outro ponto a ser ressaltado é o de Barro (1979), que sugere que uma alta volatilidade na tributação pode gerar custos maiores em média. Assim, o perfil de

\footnotetext{
${ }^{5}$ Esses resultados de irrelevância, ou ineficácia, da política monetária e de financiamento por dívida ou impostos de dado gasto público foram desenvolvidos pela abordagem Novo Clássica (HOOVER, 1988). Na sua essência, estendem o teorema central da teoria de finanças corporativas à política monetária, pois, em mercados perfeitos e sem distorções (como impostos) e desde que o valor presente dos fluxos (líquidos) de renda não seja afetado, o teorema Modigliani-Miller mostra que a composição entre dívida e ações para o financiamento das atividades reais da firma não afeta o seu valor de mercado.
} 
vencimentos da dívida torna-se um importante instrumento para amenizar a variação dos impostos.

A terceira premissa diz respeito aos mercados completos e informação simétrica. Sob essas hipóteses, os agentes conseguiriam se precaver perfeitamente contra a incerteza, igualando marginalmente o retorno dos diferentes títulos da dívida. As alocações da economia, portanto, se tornariam eficientes. No entanto, quando essas hipóteses não são verificadas, Goldfajn e Paula (1999) afirmam que a composição da dívida pública se torna um importante instrumento para a partilha de risco, para a suavização de impostos (no caso de existência de distorções tributárias) e para a construção de credibilidade por parte do governo.

Como sabemos que, na prática, as premissas acima são pouco realistas, se faz necessário um estudo aprofundado a respeito da composição ótima da dívida, pois diferentes composições trazem diferentes resultados em termos de bem-estar social. Assim, para chegar a uma composição desejável, além de lidar com o tradeoff entre risco e custo esperado, a autoridade fiscal deve estar atenta a várias outras variáveis. Destacaremos, logo abaixo, com base em Goldfajn e Paula (1999), Giavazzi e Missale (2004) e Mattos (2005), as seguintes: (i) volatilidade orçamentária, (ii) sinalização de comprometimento, (iii) os efeitos na política monetária, (iv) hedge ao setor privado, (v) risco de rolagem, (vi) liquidez e (vii) desenvolvimento do mercado de capitais.

Em determinadas situações pode ser interessante para o governo utilizar a composição da dívida como forma de reduzir a volatilidade orçamentária. A partir da calibragem da composição de sua dívida, o governo faria um hedge como forma de se precaver contra variações imprevistas nos gastos, receitas e valor de seus ativos. Um exemplo seria a proposta de títulos indexados à taxa de crescimento (BORENSZTEIN E MAURO, 2002), que restringiria a margem de variação da relação dívida/PIB. ${ }^{6} \mathrm{O}$ ideal, apontado pela literatura, seria, portanto, encontrar indexadores positivamente correlacionados com as receitas públicas e/ou preço dos ativos do governo e indexadores negativamente correlacionados com os gastos primários.

\footnotetext{
${ }^{6}$ Para essa proposta, no entanto, o problema seria a baixa demanda por esse tipo de título. Mesmo com essa dificuldade, ainda sim, serve como um exemplo das possibilidades do governo para reduzir a variabilidade de seu orçamento.
} 
A sinalização de comprometimento aparece quando o governo quer demonstrar que está comprometido com, por exemplo, a estabilidade de preços. Nesse caso, ao emitir títulos da dívida indexados por índices de preços, ele acaba fazendo um compromisso crível, pois será penalizado caso não cumpra a promessa de baixa inflação: acabará gastando mais com o pagamento de juros. O mesmo poderia ocorrer com uma promessa relacionada ao comportamento do câmbio.

A escolha da estratégia da gestão da dívida também passa pela maior ou menor eficácia da política monetária. Como vimos anteriormente, a restrição intertemporal do governo é uma das principais conexões entre a política monetária e a política fiscal. A indexação de parte da dívida pela taxa de juros prejudica os efeitos da política monetária de duas formas: (i) ao aumentar ainda mais as despesas do Tesouro, no caso de uma subida da taxa de juros e (ii) através do efeito-riqueza sobre os detentores de títulos. Assim, caso deseje aumentar o poder da política monetária, o governo deve reduzir a parcela da dívida indexada pelas taxas de juros, arcando, obviamente, com os custos da operação. ${ }^{7}$

A administração da dívida pública também pode ser utilizada como forma de fornecer hedge ao setor privado. Principalmente em países com mercado de capitais pouco desenvolvido, a estrutura da dívida teria a função de completar mercados, desenvolvendo o mecanismo de risk-sharing. Mattos (2005) ressalta que o fornecimento de hedge não seria puramente uma concessão ao setor privado. No caso de títulos indexados pelo câmbio, ele seria, antes de qualquer coisa, uma forma de evitar pressões inflacionárias desnecessárias oriundas do mercado cambial.

O governo também deve estar atento ao risco de rolagem. Para minimizar esse risco, o ideal é estabelecer os vencimentos não concentrados no tempo, pois, quando eles estão concentrados em uma mesma data, os investidores saberão que o governo terá que rolar um volume grande da dívida ${ }^{8}$. Assim, caso um choque atinja a economia, os efeitos podem se tornar mais

\footnotetext{
${ }^{7}$ Para esse ponto, ver Pastore (1996) e vários textos contidos em Bacha e Chrysostomo (2006), que discutem o papel e o fim das LFTs. Pires e Andrade (2009) também observam essas conclusões para um modelo de curto prazo, onde quanto maior a indexação da dívida pública à taxa de juros, maior é a duração do ciclo econômico. ${ }^{8}$ Barcinski (1998) dedica um capítulo de sua dissertação ao risco da dívida pública sob a ótica do seu gerenciador. Assim, baseado em alguns modelos clássicos, como o de Alesina et al. (1990), ele define que o gestor deve se preocupar com o alongamento da dívida e com a não concentração em poucos vencimentos. A partir disso, então, ele constrói três índices que buscam ajudar na análise da situação da dívida: o índice de dispersão (ID), o índice de alongamento (IA) e o índice de alongamento-dispersão (IAD). Esses índices também são utilizados em Carneiro e Wu (2005).
} 
intensos. No entanto, vencimentos concentrados apresentam a vantagem de completar e aperfeiçoar o mercado. Assim, há um tradeoff entre um risco de rolagem maior combinado com um mercado mais completo e um risco de rolagem menor juntamente com um mercado mais imperfeito.

Em relação à liquidez, o governo enfrenta mais um tradeoff. Se por um lado quanto maior a liquidez menor é o custo da dívida, por outro lado, quanto maior a liquidez, menos potentes são os efeitos da política monetária. Logo, ao escolher uma dívida mais líquida, ele pode estar prejudicando a eficácia da política monetária.

A última variável destacada de atenção para o governo é o desenvolvimento do mercado de capitais. Isto ocorre porque este mercado é plenamente influenciado pela gestão da dívida pública do país, sendo que uma dívida cara, de curto prazo, por exemplo, acaba inibindo o seu desenvolvimento (BACHA E CHRYSOSTOMO, 2006). Novaes (2006) destaca que as experiências internacionais mostram que os mercados de capitais nacionais tendem a estabelecer seus padrões de preços, indexadores e prazos mirando a dívida pública de seus respectivos países ${ }^{9}$. Assim, se o governo busca desenvolver o mercado de capitais, deve levar isso em conta na formulação de sua estratégia de administração da dívida.

Tendo apresentado essas variáveis, observamos que a escolha de diferentes indexadores para os títulos da dívida é um dos instrumentos que permitem que o governo atue. No entanto, o prazo da dívida também é um importante instrumento que o governo utiliza para atingir os seus objetivos em relação às variáveis apresentadas.

Para Giavazzi e Pagano (1990), o alongamento do prazo (maturidade) torna a economia menos suscetível a ataques especulativos, à medida que diminui a fração da dívida a ser renovada em termos desfavoráveis. Com isso, haveria a redução da vulnerabilidade do país, contribuindo para a redução do custo da dívida. Resultados similares são encontrados em Alesina, Prati e Tabellini (1990). Apesar das vantagens em relação ao alongamento, tem-se que o prêmio de risco exigido pelos investidores é, em geral, maior para títulos mais longos. Por essa razão, existem estudos que defendem o não-alongamento da dívida pública (para o

\footnotetext{
${ }^{9}$ Ressalta-se novamente o papel dos títulos prefixados na construção da curva de juros, que serve de referência para todo o mercado.
} 
Brasil, por exemplo, Llussá (1997) ${ }^{10}$, Silva e Mendonça (2007) e Alfaro e Kanczuk (2007) ${ }^{11}$ ). De qualquer jeito, o fato é que o alongamento, realizado em condições favoráveis, pode servir para reduzir a volatilidade orçamentária, reduzir o risco de rolagem e favorecer o desenvolvimento do mercado de capitais.

Nesta seção, foram apresentadas as variáveis mais relevantes a serem consideradas na formulação de estratégias ótimas para o gerenciamento da dívida pública, bem como os principais instrumentos à disposição do Tesouro e alguns modelos clássicos presentes na literatura. Na seção a seguir, pretende-se expor os principais conceitos de dívida pública, analisar os fatores que afetam a sua evolução e apresentar o desenho institucional para a gestão da dívida brasileira, realizada pelo Tesouro.

\subsection{A Dívida Pública no Brasil: conceitos e gestão}

\subsubsection{Conceitos}

Para o melhor entendimento dos fatores que afetam a evolução da dívida pública no Brasil, o primeiro passo é a solidificação o conceito do que é a dívida pública. Para isso, iniciamos com as definições de Dívida Líquida do Setor Público (DLSP) e de Dívida Pública Federal (DPF).

\section{DLSP (Dívida Líquida do Setor Público)}

Esse é o indicador mais utilizado pelo governo para decisões de política econômica e é ele que dá origem à relação Dívida/PIB, amplamente difundido na análise econômica. É referente ao setor público não financeiro mais o Banco Central, abrangendo, por definição, a administração direta e indireta das esferas federais, estaduais e municipais, além das empresas

\footnotetext{
${ }^{10}$ Llussá (1997) mostrou que, nos primeiros anos logo após a implementação do Plano Real, o alongamento da dívida pública brasileira seria inviável, em um contexto onde predominava baixo grau de credibilidade e fragilidade do sistema financeiro e político. Pagar-se-ia um prêmio de risco muito elevado, sendo preferível, portanto, o não alongamento da dívida.

${ }^{11}$ Alfaro e Kanczuk (2007) constroem um modelo de equilíbrio geral dinâmico estocástico para analisar a questão do alongamento da divida pública. Basicamente, a análise é feita através de três canais: prêmio de maturidade, sustentabilidade e suavização de impostos. O modelo é formulado com distorções de impostos e incerteza acerca do comportamento e tipo de governo. A idéia é parecida com a encontrada em Alesina et al. (1990), mas eles modelam o default diferentemente: o país que dá o default não é excluído permanentemente do mercado financeiro; seu custo é que ele passa a contar com maiores taxas de juros após o calote.

O modelo é constituído por duas economias (uma com a dívida de um período e a outra com a dívida de dois períodos) e os autores o calibram com dados referentes ao Brasil e aos EUA. Os resultados mostram que, para ambos os casos, a dívida de curto prazo está associada a um maior grau de bem estar.
} 
estatais não financeiras, do Banco Central e do sistema público de previdência social. Inclui ainda os fundos públicos cujas fontes de recursos sejam contribuições fiscais (como o FAT ${ }^{12}$ ).

Para chegar ao resultado líquido da dívida, subtraem-se os ativos financeiros das obrigações do Setor Público ${ }^{13}$. As principais contas do passivo são a Dívida Pública Federal, a base monetária e as operações compromissadas. Dentre as contas do ativo, as mais relevantes são as reservas internacionais do Banco Central e os fundos públicos. ${ }^{14}$ Após a crise econômica iniciada em 2007, uma conta que ganhou importância no ativo do setor público foi a dos créditos concedidos ao BNDES (Banco Nacional de Desenvolvimento Econômico e Social), relativa aos empréstimos feitos pelo Tesouro a este banco para que ele atuasse anticiclicamente durante a crise ${ }^{15}$.

\section{DPF (Dívida Pública Federal)}

Como vimos acima, a DPF integra a DLSP, como um de seus principais componentes. Ela se divide em duas: a DPMFi, que é a Dívida Pública Mobiliária Federal Interna, e a DPFe, que é a Dívida Pública Federal Externa. A diferença entre as duas é a moeda de denominação; enquanto na primeira a dívida é denominada em reais, na segunda ela é denominada em moeda estrangeira ${ }^{16}$.

A DPMFi é financiada por meio de vários títulos, sendo que os principais estão listados abaixo:

- LTNS: Letras do Tesouro Nacional. São títulos prefixados, que pagam a quantia de R \$1.000 no vencimento. Portanto, seu preço de negociação já embute a taxa de juros da operação. Não pagam cupom de juros.

\footnotetext{
${ }^{12}$ Fundo de Amparo ao Trabalhador.

${ }^{13} \mathrm{O}$ Banco Central divulga mensalmente as principais estatísticas referentes às contas públicas, através de sua Nota para a imprensa - política fiscal.

${ }^{14}$ Cabe lembrar ainda que a DLSP é utilizada como base para o cálculo da Necessidade de Financiamento do Setor Público (NFSP), também conhecida como o resultado nominal "abaixo da linha".

${ }^{15}$ Em 2009 e 2010, o Tesouro realizou aportes de R\$ 180 bilhões no BNDES, através das Leis 11.948/09 e 12.249/10. Essa foi uma das medidas anticíclicas adotadas pelo governo para enfrentar a crise financeira recente. Como esta teve origem no setor financeiro, a falta de liquidez e crédito ameaçou colocar a economia numa recessão ainda maior. Assim, os bancos públicos foram usados pelo governo federal para estimular a economia e não deixar que o crédito sofresse um grande colapso. Os aportes do Tesouro no BNDES, contudo, apresentam um custo fiscal e, por isso, vêm causando um intenso debate econômico na mídia. Uma das conseqüências imediatas foi um grande salto na dívida bruta.

${ }^{16}$ Atualmente, como veremos com mais detalhes a seguir, a DPMFi representa mais de 90\% da DPF.
} 
- $\quad$ NTN-Fs: Notas do Tesouro Nacional, série F. Esses títulos também são prefixados, porém pagam uma taxa de juros preestabelecida semestralmente.

- LFTs: Letras Financeiras do Tesouro. São títulos indexados à Taxa Selic. Não pagam cupom de juros, portanto o investidor só recebe o principal corrigido no vencimento.

- NTN-Bs: Notas do Tesouro Nacional, série B. São títulos indexados ao IPCA, que podem ou não pagar cupom de juros (NTN-B ou NTN-B principal). Assim, pagam uma taxa preestabelecida acrescida da variação do indexador.

Além desses, temos as NTN-Cs e NTN-Ds, indexadas, respectivamente, ao IGP-M e ao câmbio. Vale ressaltar que estes dois títulos não são mais emitidos pelo Tesouro Nacional. Somados, os títulos apresentados são os mais importantes para o financiamento da DPF, sendo responsáveis por mais de $90 \%$ desta.

Por outro lado, DPFe é financiada por meio de títulos e também por meio de empréstimos contratuais. Os principais títulos são os Global US\$ Bonds e os Euro Bonds, denominados, respectivamente, em dólar e euro, além dos Global BRL Bonds, denominados em reais, mas que tem seu fluxo de pagamento em dólar, por isso sendo classificado como parte da DPFe.

A tabela 1 abaixo permite a ilustração do que foi apresentado acima em relação aos conceitos de dívida. Podemos verificar que a DPF está presente no balanço do setor público, através de seus dois componentes (DPMFi e DPFe). A DPMFi é a soma das contas Dívida Mobiliária do Tesouro Nacional e Dívidas Securitizadas e TDA enquanto a DPFe é a Dívida Externa Líquida do Governo Federal.

Percebe-se ainda que as reservas internacionais estão na conta Dívida Externa Líquida do Banco Central, que se apresenta como a principal conta redutora da DLSP. Outra conta que não havia sido citada anteriormente é a Renegociação Lei 9.496/1997 e Proes, que apareceu como ativo do Governo Federal e se refere ao refinanciamento das dívidas dos Estados. Assim, basicamente, enquanto ela está no ativo da União, ela também está no passivo dos Estados, praticamente se anulando pra efeitos práticos da DLSP. 
Tabela 1 - Dívida Líquida do Setor Público - Brasil

\begin{tabular}{|c|c|c|c|c|}
\hline \multirow{3}{*}{$\begin{array}{c}\text { Composição da Dívida Líquida do } \\
\text { Setor Público }\end{array}$} & \multirow{2}{*}{\multicolumn{2}{|c|}{$\begin{array}{c}2009 \\
\text { Dezembro }\end{array}$}} & \multirow{2}{*}{\multicolumn{2}{|c|}{$\begin{array}{l}2010 \\
\text { Julho }\end{array}$}} \\
\hline & & & & \\
\hline & Saldos & $\begin{array}{c}\% \\
\text { PIB }\end{array}$ & Saldos & $\begin{array}{c}\% \\
\text { PIB }\end{array}$ \\
\hline Dívida líquida total & 1345325 & 42.8 & 1406626 & 41.7 \\
\hline 1. Dívida interna líquida & 1633255 & 52.0 & 1731370 & 51.3 \\
\hline Governo Federal & 876731 & 27.9 & 931542 & 27.6 \\
\hline Dívida mobiliária do Tesouro Nacional & 1381841 & 44.0 & 1493245 & 44.2 \\
\hline Dívidas securitizadas e TDA & 16575 & 0.5 & 15873 & 0.5 \\
\hline Outros & -149778 & -4.8 & -177200 & -5.3 \\
\hline Recursos do FAT & -159633 & -5.1 & -165734 & -4.9 \\
\hline Renegociação (Lei no 9.496/1997 e Proes) & -366707 & -11.7 & -386787 & -11.5 \\
\hline Créditos junto ao BNDES & -129237 & -4.1 & -211465 & -6.3 \\
\hline Relacionamento com Banco Central & 283673 & 9.0 & 363610 & 10.8 \\
\hline Conta única & -406354 & -12.9 & -324947 & -9.6 \\
\hline Dívida mobiliária na carteira do Bacen & 637815 & 20.3 & 677227 & 20.1 \\
\hline Equalização cambial & 52212 & 1.7 & 11330 & 0.3 \\
\hline Banco Central do Brasil & 368999 & 11.7 & 397338 & 11.8 \\
\hline Base monetária & 166073 & 5.3 & 162528 & 4.8 \\
\hline Operações compromissadas & 454710 & 14.5 & 403827 & 12.0 \\
\hline Outros depósitos no Bacen & 63292 & 2.0 & 227437 & 6.7 \\
\hline Créditos do Bacen às inst. financeiras & -28306 & -0.9 & -30070 & -0.9 \\
\hline Demais contas do Bacen & -3097 & -0.1 & -2774 & -0.1 \\
\hline Relacionamento com Governo Federal & -283673 & -9.0 & -363610 & -10.8 \\
\hline Governos estaduais & 335899 & 10.7 & 346607 & 10.3 \\
\hline Governos municipais & 54059 & 1.7 & 57994 & 1.7 \\
\hline Empresas estatais & -2433 & -0.1 & -2110 & -0.1 \\
\hline 2 . Dívida externa líquida & -287930 & -9.2 & -324744 & -9.6 \\
\hline Governo Federal & 94993 & 3.0 & 91758 & 2.7 \\
\hline Banco Central do Brasil & -408188 & -13.0 & -444213 & -13.2 \\
\hline Governos estaduais & 14440 & 0.5 & 16645 & 0.5 \\
\hline Governos municipais & 2007 & 0.1 & 2022 & 0.1 \\
\hline Empresas estatais & 8819 & 0.3 & 9044 & 0.3 \\
\hline Federais (exceto Petrobras) & 4772 & 0.2 & 5044 & 0.1 \\
\hline Estaduais & 4046 & 0.1 & 3999 & 0.1 \\
\hline
\end{tabular}

Fonte: Banco Central

Portanto, após essas definições, fica mais clara a questão da gestão da dívida pública no Brasil. O ponto principal é que essa gestão deve ter em mente as principais contas do ativo financeiro e do passivo do setor público, que determinam a evolução da dívida. No entanto, o instrumento de que o governo dispõe para realizar a gestão é o gerenciamento da Dívida Pública Federal, através da escolha dos indexadores e prazo dos títulos emitidos pelo Tesouro. Por exemplo, o Tesouro não controla diretamente a aplicação dos recursos, como o FAT nem os créditos junto ao BNDES. Desta maneira, segue abaixo um modelo simplificado, 
apresentado por Bevilaqua e Garcia (2002), que resume essas colocações e determina em linhas gerais a evolução da dívida pública de um país.

\section{A evolução da Dívida Pública}

Conforme colocado acima, podemos analisar a evolução da DLSP através da restrição orçamentária do setor público, conforme exposto por Bevilaqua e Garcia (2002). Parte-se da seguinte equação:

$$
\frac{M_{t}-M_{t-1}}{P_{t}}+\frac{B_{t}-B_{t-1}}{P_{t}}+\frac{E_{t}\left(B_{t}^{*}-B_{t-1}^{*}\right)}{P_{t}} \equiv \frac{D_{t}}{P_{t}}+i_{t} \frac{B_{t-1}}{P_{t}}+i_{t}^{*} \frac{E_{t}}{P_{t}} B_{t-1}^{*}-\frac{A_{t}}{P_{t}}+\frac{H_{t}}{P_{t}}
$$

onde $M$ é a base monetária, $B$ é a dívida líquida doméstica, $B^{*}$ é a dívida externa líquida das reservas internacionais, $E$ é a taxa de câmbio nominal, $D$ é o resultado primário ${ }^{17}, i$ é a taxa de juros doméstica, $i^{*}$ a taxa de juros internacional, $A$ representa as receitas de privatizações, $H$ corresponde aos passivos contingentes e $P$ é o nível de preços.

Dividindo a equação (1.1) por $Y_{t}$, chegamos ao seguinte resultado,

$$
\frac{M_{t}-M_{t-1}}{P_{t} Y_{t}}+\frac{B_{t}-B_{t-1}}{P_{t} Y_{t}}+\frac{E_{t}\left(B_{t}^{*}-B_{t-1}^{*}\right)}{P_{t} Y_{t}} \equiv \frac{D_{t}}{P_{t} Y_{t}}+i_{t} \frac{B_{t-1}}{P_{t} Y_{t}}+i_{t}^{*} \frac{E_{t}}{P_{t} Y_{t}} B_{t-1}^{*}-\frac{A_{t}}{P_{t} Y_{t}}+\frac{H_{t}}{P_{t} Y_{t}}
$$

ou simplesmente

$$
\frac{B_{t}}{P_{t} Y_{t}}+\frac{E_{t} B_{t}^{*}}{P_{t} Y_{t}}=\frac{B_{t-1}}{P_{t} Y_{t}}\left(1+i_{t}\right)+\frac{E_{t} B_{t-1}^{*}}{P_{t} Y_{t}}\left(1+i_{t}^{*}\right)-\sigma_{t}+d_{t}-a_{t}+h_{t}
$$

onde $\sigma_{t}, d_{t}, a_{t}$ e $h_{t}$ são, respectivamente, a senhoriagem, o resultado primário, as receitas de privatização e os passivos contingentes, todos sobre o PIB. Ainda podemos reescrever (1.3) da seguinte forma:

\footnotetext{
${ }^{17}$ Nesta equação, déficits primários são registrados com o sinal positivo, enquanto superávits primários são lançados com o sinal negativo. Note, que, sob esta definição, o D pode ser interpretado como $\mathrm{G}$ - T , onde $\mathrm{G}$ são os gastos não-financeiros do governo e T são os impostos.
} 
$b_{t}+b_{t}^{*}=\frac{B_{t-1}}{P_{t-1} Y_{t-1}} \frac{1+i_{t}}{\frac{P_{t} Y_{t}}{P_{t-1} Y_{t-1}}}+\frac{E_{t-1}}{P_{t-1} Y_{t-1}} B_{t-1}^{*} \frac{E_{t}}{E_{t-1}} \frac{\left(1+i_{t}^{*}\right)}{\frac{P_{t} Y_{t}}{P_{t-1} Y_{t-1}}}-\sigma_{t}+d_{t}-a_{t}+h_{t}$

chegando a

$b_{t}+b_{t}^{*}=b_{t-1} \frac{\left(1+i_{t}\right)}{\left(1+\pi_{t}\right)\left(1+g_{t}\right)}+b_{t-1}^{*} \frac{\left(1+i_{t}^{*}\right)\left(1+\varepsilon_{t}\right)}{\left(1+\pi_{t}\right)\left(1+g_{t}\right)}-\sigma_{t}+d_{t}-a_{t}+h_{t}$

onde $b_{t}$ e $b_{t}^{*}$ correspondem às dívidas líquidas interna e externa do setor público em relação ao PIB, e $\pi, g$ e $\varepsilon$ são as taxas de inflação, crescimento do PIB e desvalorização da taxa de câmbio nominal.

Essa equação nos mostra a evolução da dívida líquida do governo em relação ao PIB, incluindo a dívida em moeda estrangeira. O estoque da dívida líquida em $t$ é igual ao estoque da dívida líquida interna em $t-1$, multiplicada pela sua taxa de juros e dividida pela inflação e pelo crescimento em $t$, somada ao estoque da dívida líquida em moeda estrangeira em $t-1$, multiplicada pela sua taxa de juros e pela desvalorização cambial em $t$ e dividida pela inflação e crescimento em $t$. Além disso, subtraem-se a senhoriagem e as receitas de privatizações, enquanto somam-se o reconhecimento de novas dívidas (passivos contingentes) e o resultado primário (com sinal positivo para déficit), tudo em relação ao produto em $t^{18}$.

Desta maneira, podemos analisar os fatores que implicam em aumento ou redução da dívida líquida em relação ao PIB no curto prazo: o crescimento e a inflação, as receitas de privatizações e as receitas de senhoriagem causam a queda da relação Dívida/PIB, enquanto os déficits primários, o reconhecimento de passivos contingentes, a desvalorização cambial e a remuneração da dívida passada provocam o aumento da relação Dívida/PIB.

\subsubsection{O desenho institucional para a gestão da Dívida Pública Federal (DPF)}

Nesta subseção, vamos tentar descrever sucintamente como está estruturada a gestão atual da dívida pública brasileira, a cargo da Secretaria do Tesouro Nacional - Ministério da

\footnotetext{
${ }^{18}$ A taxa de juros das dívidas líquidas interna e externa se referem ao seu custo nominal médio, dado pela taxa de remuneração de seus diferentes componentes do passivo e ativo que entram no conceito de dívida líquida.
} 
Fazenda. $^{19}$

Como já foi apontado anteriormente, em 1999 o governo brasileiro adotou uma nova política macroeconômica, baseada no tripé metas de inflação, superávit primário e câmbio flutuante. O novo ambiente institucional era fortemente baseado na transparência e credibilidade e, para isso, várias mudanças foram sendo colocadas em prática para atender esses pressupostos.

Neste cenário de estabilidade, alguns fatores chamavam atenção para a necessidade de uma gestão técnica da dívida pública, menos focada no curto prazo. Em primeiro lugar, as crises que atingiram os mercados emergentes ao longo dos anos 90, explicitaram a exigência de se adotar boas práticas na gestão da dívida pública para assegurar, ou ao menos não prejudicar, a estabilidade econômica. Em segundo lugar, a consolidação do novo contexto macroeconômico possibilitava maiores graus de liberdade para a gestão da dívida pública, abrindo uma oportunidade de pensar no longo prazo, conforme ressaltado por Alves e Silva (2009).

Desta maneira, em vista desta necessidade, o governo brasileiro, seguindo recomendações do FMI e Banco Mundial, procurou reformular toda a gestão de sua dívida pública, baseado no estudo das melhores práticas internacionais ${ }^{20}$.

O primeiro passo dessas reformulações foram as medidas legais, isto é, a modernização da legislação que disciplina as práticas da gestão da dívida. Um exemplo que pode ser citado nesse quesito foi a proibição da emissão de títulos em mercado pelo Banco Central ${ }^{21}$. Em seguida, houve uma reestruturação da área dentro do Tesouro diretamente responsável pelo gerenciamento da dívida pública. A Secretaria-Adjunta da Dívida Pública passou a ser dividida em três áreas, relativas às atividades de back, middle e front office ${ }^{22}$. Além disso, foi criado um Comitê de Gerenciamento da Dívida Pública Federal, formado pelo secretárioadjunto, pelos chefes de cada office e por coordenadores da Secretaria Adjunta. O comitê teria

\footnotetext{
${ }^{19}$ As referências usadas aqui são basicamente Rocha (2009), Alves e Silva (2009), PAF (2010) e Cabral, Lopes et al. (2008).

${ }^{20}$ FMI e Banco Mundial (2001) - Guidelines for public debt management.

${ }^{21}$ Essa medida buscou concentrar a tarefa de gestão da dívida em uma só unidade governamental, separando-se, assim, as funções da política monetária e fiscal.

${ }^{22}$ As back, middle e front offices são, respectivamente, a CODIV (Coordenação Geral do Controle da Dívida Pública), a COGEP (Coordenação Geral de Planejamento Estratégico da Dívida Pública) e a CODIP (Coordenação Geral de Operações da Dívida Pública). Para mais detalhes, consultar Rocha (2009) ou o site do Tesouro.
} 
funções importantes, como definir as diretrizes de médio e longo prazo para a Dívida Pública Federal e também as estratégias de curto prazo.

Posteriormente, a credibilidade e transparência, também recomendadas pelas guidelines, foram sendo trabalhadas através de uma série de relatórios e documentos que passaram a ser disponibilizados ao público. Rocha (2009) destaca que, ao reduzir as incertezas do mercado, uma política transparente possibilita a diminuição da volatilidade e dos prêmios de risco exigidos pelos investidores. Como exemplos destes documentos, temos o Plano Anual de Financiamento (PAF) e o Relatório Anual da Dívida Pública. O primeiro divulga as diretrizes que norteiam a gestão da dívida, bem como as premissas para o planejamento, as estratégias de emissão e as metas para os principais indicadores da dívida. O segundo analisa a gestão da dívida do ano que passou, apresentando a evolução dos indicadores ao longo do ano e detalhando os acontecimentos relevantes. ${ }^{23}$

Hoje em dia, com todo esse arcabouço, pode-se dizer que a gestão da dívida pública brasileira tem servido de referência para países que estão em estágios iniciais ou intermediários de desenvolvimento desse processo (PAF, 2010). O Tesouro busca compartilhar as suas experiências por meio de seminários, congressos, criação de fóruns de discussão (como o LAC Debt Group - Grupo de Especialistas em Gerenciamento da Dívida Pública da América Latina e Caribe). Além destas participações, o reconhecimento da qualidade de sua gestão é evidenciado através de alguns prêmios, tais como o Emissor do Ano (2008) e IIF (2009) ${ }^{24}$.

Tendo apresentando um pouco da estrutura institucional, podemos então discorrer um pouco a respeito das estratégias que são adotadas pelo Tesouro. Neste ponto, é importante reproduzir o objetivo perseguido por ele, isto é, os objetivos da gestão da dívida pública, que é

suprir de forma eficiente as necessidades de financiamento do governo federal, ao menor custo de financiamento no longo prazo, respeitando-se a manutenção de níveis prudentes de risco. Adicionalmente, busca-se contribuir para o bom funcionamento do mercado de títulos públicos

\footnotetext{
${ }^{23}$ O primeiro PAF foi publicado para o ano de 2001 e o primeiro Relatório Anual da Dívida Pública foi publicado em relação a 2003. Anteriormente, o segundo era parte do primeiro. Outros documentos que merecem ser destacados são o Relatório Mensal da Dívida Pública, o Cronograma Mensal de Emissões, os Informes da Dívida e Apresentações para Investidores.

${ }^{24}$ O prêmio "Emissor do Ano - América Latina", de 2008, foi dado pela Emerging Markets, parte da Euromoney Institutional Investor, para a emissão do Global 2017 pelo Tesouro Nacional. Além da operação ter conseguido um spread de apenas 140 pontos em relação ao Treasury com vencimento similar, ela conseguiu uma demanda bem maior que a oferta. O segundo reconhecimento, da IIF, colocou o Brasil como o país emergente de melhor relação com investidores e transparência na divulgação de informações sobre contas públicas e endividamento, em um estudo com trinta países.
} 
brasileiro. (PAF, 2010).

O PAF (2010) destaca que, para atingir esse objetivo, uma das primeiras abordagens utilizadas pelo Tesouro para definir sua estratégia de longo prazo foi um modelo de gerenciamento de ativos e passivos (ALM), analisando custos e riscos e considerando todos os itens do balanço do governo federal que afetavam a dívida. Posteriormente, introduziu-se novas metodologias, como o teste de estresse, que simula o impacto negativo de um choque persistente na taxa de juros ou no câmbio não custo da dívida e indicadores estocásticos, como o Cost-at-risk (CaR) e o Cashflow-at-risk $(\mathrm{CfaR})^{25}$. Por fim, mais recentemente, o Tesouro avançou na construção de um modelo macroeconômico para chegar a composições ótimas da DPF, isto é, com um balanceamento adequado entre custo e risco.

Desta maneira, atualmente, o Tesouro busca aprimorar esse modelo, que tem como objetivo principal a formulação de um benchmark, ou seja, uma composição de dívida desejável no longo prazo. Além de ser uma recomendação do Banco Mundial e FMI, os modelos de benchmark vêm sendo implementados por uma série de países, como, por exemplo, Portugal, Suécia, Irlanda, Dinamarca e África do Sul (ALVES E SILVA, 2009).

\subsection{Conclusões}

Neste capítulo, foram apresentados os aspectos fundamentais da gestão da dívida pública, destacando a sua relevância e as principais questões envolvidas. Também foi realizada a formalização de vários conceitos relativos à dívida publica, como diferentes definições, a estrutura de ativos e passivos do governo e os principais títulos públicos. Na seção final, foi exposta a estrutura institucional existente para a administração da dívida no Brasil. No próximo capítulo, busca-se descrever a trajetória da dívida pública no país a partir dos anos 90, destacando a evolução dos indicadores de gestão, como estoque da dívida, indexadores e prazos. Será possível notar a considerável evolução que o país teve ao longo desses anos, com destaque para a mudança da composição em favor de títulos prefixados e indexados a preços, a redução quase completa da dívida externa e o alongamento dos prazos. O conhecimento da situação atual será fundamental para a reflexão sobre as estratégias a serem adotadas daqui

\footnotetext{
${ }^{25}$ Essas são medidas de risco desenvolvidas como adaptações de indicadores já existentes do ponto de vista do investidor, como o Value-at-Risk (VaR). Assim, são medidas de risco do ponto de vista do devedor. O CaR representa o valor esperado máximo que o estoque de dívida pode atingir em um dado período, para um determinado nível de significância. Já o CfaR está mais preocupado com o risco de refinanciamento e mede o valor máximo de pagamentos (fluxo) em alguma data no futuro, também para um dado nível de significância.
} 
para frente. 


\section{A TRAJETÓRIA RECENTE DOS INDICADORES DA DÍVIDA PÚBLICA BRASILEIRA}

Neste capítulo, pretende-se descrever a evolução recente dos principais indicadores relacionados à dívida pública e à sua gestão. Será possível notar como os acontecimentos macroeconômicos - internos e externos - influenciaram tanto o estoque da dívida como também na composição e no prazo dessa dívida.

\subsection{Estoque}

Vimos no capítulo anterior que existem duas medidas relevantes para o estoque da dívida nacional, a DLSP e a DPF. Além delas, há o conceito de DLSP/PIB, ou Dívida/PIB, indicador mais utilizado relativo à solvência de um país. Apesar da grande relação que esses conceitos têm entre si, cada um apresenta, entretanto, seus próprios determinantes, como veremos a seguir.

Analisando a trajetória da relação Dívida/PIB a partir de 1991, podemos destacar quatro períodos principais (Gráf. 1). O primeiro foi do início da amostra até o final de 1995, quando ela apresentou uma tendência de queda e alcançou um valor mínimo de $28 \%$ em dezembro de 1995. O segundo momento inclui uma fase de estabilidade, verificada até o meio de 1997 , seguida de um crescimento acelerado, quando atingiu $47 \%$ no início de 1999 . O terceiro período foi marcado por uma estabilidade nesse alto patamar até o meio de 2001 e numa forte elevação da relação Dívida/PIB, a partir do segundo semestre de 2001, chegando a $63 \%$ em setembro de 2002. Desde então, podemos destacar uma quarta fase, quando a Dívida/PIB apresentou um vigoroso processo de queda, atingindo $38 \%$ em novembro de 2008. Esse processo ainda sofreu uma leve interrupção ao final de 2009, quando a ela voltou a crescer, no contexto da crise financeira mundial. No entanto, o processo de queda do indicador já foi retomado, sendo que a última observação (julho/2010) indica uma Dívida/PIB de $41,7 \%{ }^{26}$.

\footnotetext{
${ }^{26}$ Para uma boa revisão sobre a evolução da dívida pública, ver Giambiagi e Além (2000) para os dois primeiros períodos e os PAFs (2000-2010) para os seguintes.
} 


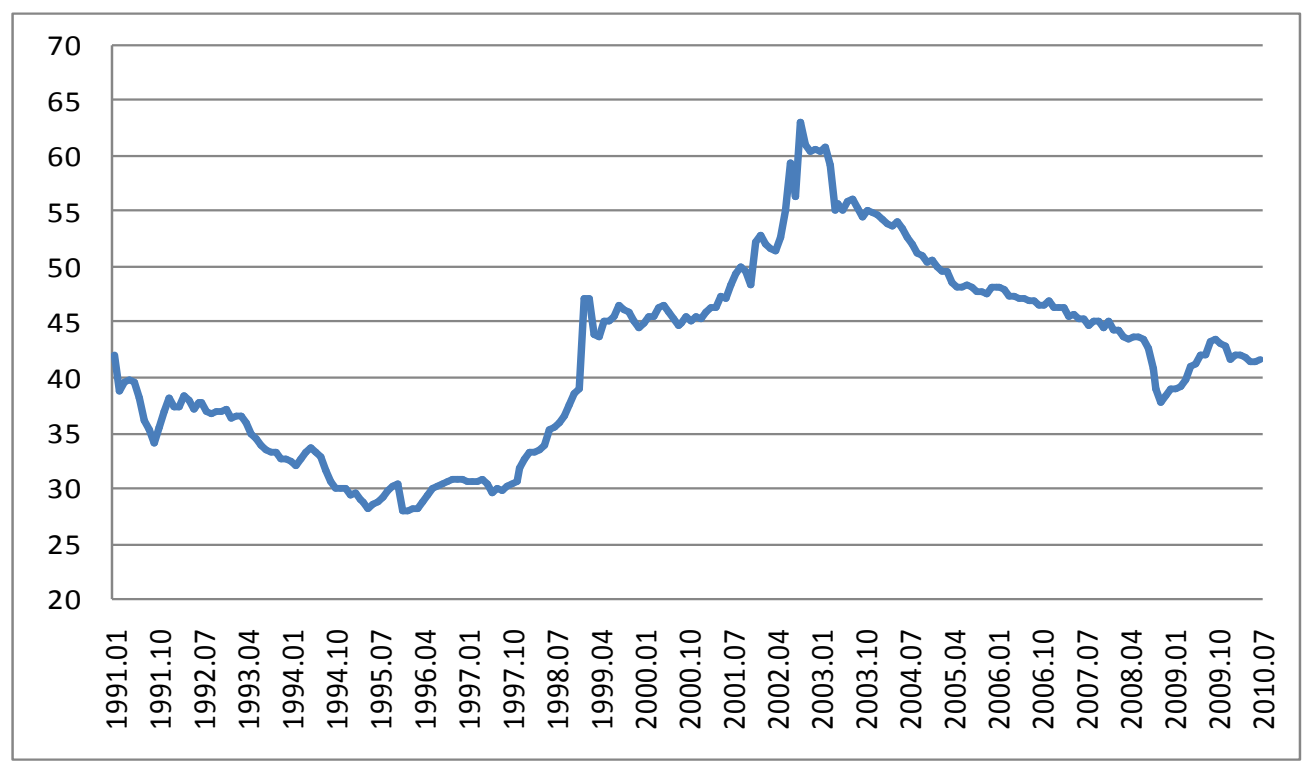

Gráfico 1 - Evolução da relação Dívida/PIB do Brasil - 1991/01 a 2010/07

Fonte de dados: Ipeadata

Pode-se tentar buscar explicações para o desempenho do indicador para os quatro períodos destacados. Para isso, voltamos à equação (1.5) apresentada no capítulo 1:

$b_{t}+b_{t}^{*}=b_{t-1} \frac{\left(1+i_{t}\right)}{\left(1+\pi_{t}\right)\left(1+g_{t}\right)}+b_{t-1}^{*} \frac{\left(1+i_{t}^{*}\right)\left(1+\varepsilon_{t}\right)}{\left(1+\pi_{t}\right)\left(1+g_{t}\right)}-\sigma_{t}+d_{t}-a_{t}+h_{t}$

Vimos que ela identifica os fatores que determinam a evolução do indicador Dívida/PIB: o custo real da dívida líquida, a taxa de crescimento, as receitas de senhoriagem, os resultados primários, as receitas de privatização e o reconhecimento de dívidas antigas ${ }^{27}$. É importante ressaltar que as dívidas interna e externa são consideradas em valores líquidos e o custo da dívida é uma média ponderada do custo de cada parcela da dívida (além da remuneração dos ativos), dependendo, portanto, fortemente de sua composição.

Tendo esses fatores em mente, podemos analisar os períodos assinalados anteriormente. Em relação ao primeiro, de janeiro de 1991 até o final de 1995, destaca-se a influência dos superávits primários conseguidos pelo governo, juntamente com uma forte taxa de crescimento entre 1993 e 1995, de 4,9\% na média (Tabela 2). Giambiagi e Além (2000) indicam que os dois principais motivos para a queda da relação Dívida/PIB entre 1990 e 1994

\footnotetext{
27 Alguns autores, como Mendonça, Pires e Medrano (2008), agrupam as receitas de privatização, o reconhecimento de dívidas antigas (passivos contingentes) e ajustes cambiais (efeito das mudanças cambiais nos itens da DLSP denominados em moeda estrangeira) em uma conta denominada ajustes patrimoniais.
} 
foram a redução significativa das Necessidades de Financiamento do Setor Público (NFSP), fazendo com que o resultado operacional médio ficasse zerado, e a obtenção de receitas expressivas com senhoriagem ${ }^{28}$.

No segundo período destacado, de 1996 ao início de 1999, observamos que a tendência de alta foi permanente. Pedras (2009) explica essa movimento pela conjugação dos seguintes fatores: (i) a rígida política monetária do período, responsável por uma taxa de juros real média extremamente elevada (aumentando o custo da dívida), (ii) o fraco desempenho das contas públicas (resultados primários) e (iii) a política de propiciar maior transparência às contas públicas, com o reconhecimento de vários passivos do setor público. Além dessas, podemos acrescentar o baixo crescimento econômico verificado no período, conforme a Tabela 2.

Tabela 2 - Crescimento do PIB e NFSP (primário) - Brasil - 1991 a 2008

\begin{tabular}{c|c|c|c|c|c}
\hline ANO & \% PIB & $\begin{array}{c}\text { NFSP } \\
\text { (primário) }\end{array}$ & ANO & \% PIB & $\begin{array}{c}\text { NFSP } \\
\text { (primário) }\end{array}$ \\
\hline 1991 & 1.06 & -2.71 & 2000 & 4.31 & -3.47 \\
1992 & -0.49 & -1.58 & 2001 & 1.36 & -3.36 \\
1993 & 4.66 & -2.18 & 2002 & 2.64 & -3.55 \\
1994 & 5.24 & -5.64 & 2003 & 1.17 & -3.89 \\
1995 & 4.75 & -0.26 & 2004 & 5.71 & -4.17 \\
1996 & 2.11 & 0.1 & 2005 & 3.16 & -4.35 \\
1997 & 3.41 & 0.96 & 2006 & 3.97 & -3.81 \\
1998 & 0.06 & -0.02 & 2007 & 6.08 & -3.91 \\
1999 & 0.27 & -3.23 & 2008 & 5.17 & -4.08 \\
\hline
\end{tabular}

Fonte: Ipeadata e STN

O momento extremo dessa etapa foi durante o biênio 1998/1999, quando, no auge dos efeitos das crises asiática e russa, o governo foi obrigado a elevar fortemente a taxa de juros. Logo em seguida, acabou abandonando o regime das bandas cambiais, fazendo com que o câmbio sofresse uma maxi-desvalorização. Em virtude do período de turbulência, com uma grande parcela da dívida indexada aos juros e ao câmbio, a relação dívida/PIB acabou dando um

\footnotetext{
${ }^{28}$ Os autores ainda citam outras causas para esse fenômeno: (i) o feriado bancário de três dias, decretado imediatamente antes do Plano Collor, que fez com que a dívida não sofresse nenhuma correção, em um contexto de altíssima inflação, (ii) o movimento de apreciação cambial que reduziu a dívida externa e (iii) um acordo da dívida externa em 1994 que eliminou parte de seu valor.
} 
grande salto, passando de 30\% (outubro de 1997) para 47\% (janeiro de 1999) ${ }^{29}$.

Para o terceiro período destacado, de meados de 1999 até o fim de $2002^{30}$, observamos que a relação Dívida/PIB se manteve mais ou menos estável até o final de 2001, mas sofreu uma forte elevação em seguida. $\mathrm{O}$ momento extremo nesta fase pode ser explicado por uma crise de confiança que atingiu a economia brasileira, quando, a partir de maio de 2002, a taxa de câmbio sofreu sucessivas desvalorizações, chegando a um pico de $\mathrm{R} \$ 3,81$ por U\$ 1,00 em outubro. Este choque estaria associado à crescente probabilidade de que o candidato de oposição à Presidência da República, Luiz Inácio Lula da Silva, fosse eleito Presidente do Brasil. Novamente, a relação dívida/PIB deu um salto, passando de 51,5\% em abril para 63\% em setembro ${ }^{31}$.

Assim, os principais fatores que atuaram positivamente sobre a dinâmica da Dívida/PIB nesse período foram o custo da dívida - em virtude das turbulências externas em 2001 e internas em 2002 - e a continuação do reconhecimento de passivos contingentes. Esses fatores foram contrabalançados pelos superávits primários obtidos.

Pêgo-Filho e Pinheiro (2004) apresentam um gráfico que quantifica o impacto de cada fator para o aumento da DLSP entre janeiro de 1996 e junho de 2003, abrangendo assim, o segundo e o terceiro período em análise (Gráf. 2). No agregado destes dois períodos, vemos que o pagamento de juros nominais teve o maior peso na explicação do aumento da DLSP, seguido do reconhecimento de dívidas e do ajuste cambial ${ }^{32}$. Os resultados primários e as receitas das privatizações atuaram no sentido contrário. Ressalta-se ainda que os principais itens incluídos em reconhecimento de dívidas são o PROES (Programa de incentivo à redução do Setor Público Estatal na atividade bancária), Securitização de dívidas diversas ${ }^{33}$, FCVS (Fundo de Compensação de Variações Salariais), PROEF (Programa de fortalecimento das instituições

\footnotetext{
${ }^{29}$ Considerando somente dezembro de 1998 e janeiro de 1999, a Dívida/PIB cresceu 8,2 pontos percentuais, passando de $38,9 \%$ para $47,1 \%$.

${ }^{30}$ Ressalta-se que em 1999 a política macroeconômica sofreu uma inflexão, quando passou de um regime de bandas cambiais para um regime sustentado por um tripé formado por metas de inflação, superávits primários e câmbio flutuante.

${ }^{31}$ Vale destacar que a DPF estava extremamente indexada em juros e câmbio.

${ }^{32}$ Embora os autores destaquem que, dos R $\$ 724$ bilhões de juros nominais, quase R $\$ 200$ bilhões foram de juros sobre as dívidas reconhecidas. Logo, essa parcela poderia estar na conta do reconhecimento de dívidas.

${ }^{33}$ Inclui dívidas securitizadas ao âmbito da Lei 9.496/97 (Renegociação das dívidas dos Estados com a União).
} 
financeiras federais) e transferências para fundos de pensão ${ }^{34}$.

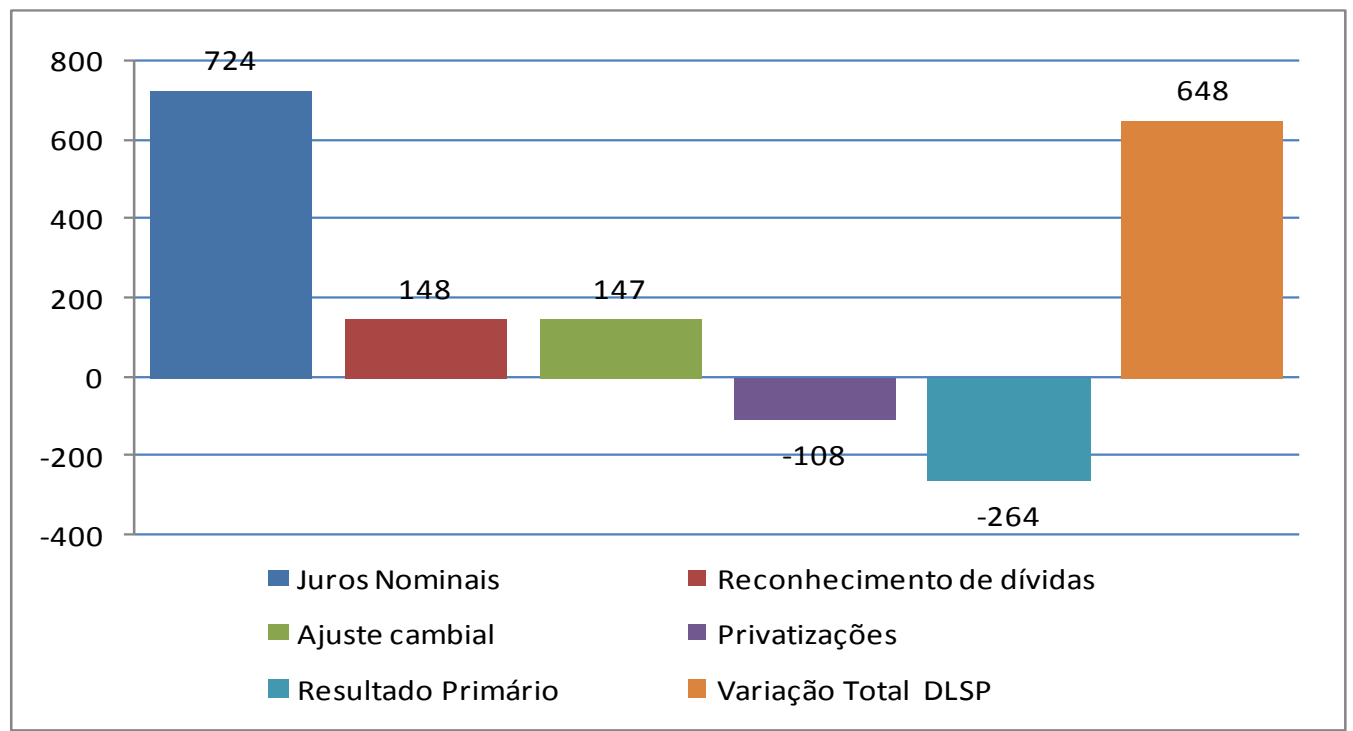

\section{Gráfico 2 - Fatores Condicionantes da DLSP - jan/96 a jun/03 - R\$ Bilhões de jun/03}

Fonte de dados: Pêgo-Filho e Pinheiro (2004)

Por último, no quarto período destacado, que vai de 2003 até o presente, a relação Dívida/PIB tem o seu movimento de queda explicado principalmente pelos elevados superávits primários, pela queda no custo médio da dívida e principalmente pelo crescimento econômico, que atuou sobre o denominador da relação. Já as privatizações e o reconhecimento de dívidas deixaram de ter um peso sobre a variação da DLSP. É possível ver esses fatores, ano a ano, na Tabela 3. O próximo passo é comparar a evolução da DLSP e da DPF, entre 1995 e 2010 (Gráf. 3). Observamos que, embora caminhem bem próximas, a DPF cresceu a taxas mais altas do que a DLSP entre 1995 e 1998 e também mais recentemente, a partir de 2005.

Bevilaqua e Garcia (2002) analisam os fatores que causaram o aumento nominal da dívida mobiliária federal entre 1995 e 1998 e encontram que os resultados nominais do setor público responderam por $63 \%$ do aumento, seguidos pela acumulação de ativos (FAT, reservas internacionais, créditos do $\mathrm{BC}$ a instituições financeiras e renegociação de dívida com os Estados $^{35}$ ), com $62,5 \%$ de participação. O crescimento de outras contas do passivo teve uma

\footnotetext{
${ }^{34}$ Muitos autores consideram todos esses itens como "reconhecimento de dívidas antigas". Assim, esse conceito acaba incluindo itens que não são necessariamente são dívidas antigas, como alguns componentes de ajuste fiscal (PROES e o PROEF, por exemplo). Para mais detalhes, ver Versiani (2003) e Pêgo-Filho e Pinheiro (2004).

35 Como exemplo, Versiani (2003) destaca que, sob o amparo da Lei no 9.697, de 1997 (renegociação das dívidas), o governo federal emitiu aproximadamente R\$ 120 bilhões em títulos (valores de junho de 1999) para
} 
participação negativa de 25,5\%. Esse resultado explica o maior crescimento da DPF (mobiliária) em relação à DLSP: um aumento dos ativos financeiros do setor público, quando financiada pela dívida mobiliária, causa uma elevação desta sem aumentar a DLSP, pois os ativos são descontados da dívida bruta, deixando a dívida líquida inalterada.

Em relação aos últimos anos, pode-se dizer que a acumulação de ativos também é responsável por parte do aumento da dívida mobiliária, cabendo destaque às reservas internacionais, aos recursos do FAT, à conta da renegociação de dívidas com os Estados e aos empréstimos do Tesouro ao BNDES. Essas razões ajudam a explicar o maior aumento da DPF em relação à $\mathrm{DLSP}^{36}$.

Tabela 3 - Evolução da Dívida Líquida - Fatores condicionantes - 2002 a 2009

\begin{tabular}{|c|c|c|c|c|c|c|c|c|}
\hline Discriminação & 2002 & 2003 & 2004 & 2005 & 2006 & 2007 & 2008 & 2009 \\
\hline Dívida líquida total - saldo (R\$ milhões) & 896,096 & 933,630 & 981,973 & $1,035,278$ & $1,112,701$ & $1,200,799$ & $1,153,631$ & $1,345,325$ \\
\hline Dívida líquida - var. ac. ano & 216,019 & 37,534 & 48,342 & 53,305 & 77,423 & 88,098 & $-47,168$ & 191,694 \\
\hline Fatores condicionantes: & 216,019 & 37,534 & 48,342 & 53,305 & 77,423 & 88,098 & $-47,168$ & 191,694 \\
\hline NFSP & 65,333 & 87,232 & 54,128 & 72,600 & 83,890 & 71,492 & 57,240 & 104,622 \\
\hline Primário & $-47,440$ & $-56,829$ & $-73,844$ & $-84,431$ & $-76,828$ & $-89,730$ & $-106,420$ & $-64,517$ \\
\hline Juros nominais & 112,774 & 144,061 & 127,972 & 157,031 & 160,718 & 161,222 & 163,660 & 169,139 \\
\hline Ajuste cambial & 147,970 & $-66,101$ & $-18,011$ & $-20,520$ & $-6,890$ & 21,016 & $-77,373$ & 79,754 \\
\hline Dívida mobil. interna indexada ao câmbio & 76,662 & $-22,715$ & $-3,335$ & $-4,554$ & $-2,222$ & $-2,432$ & 3,180 & $-3,414$ \\
\hline Dívida externa - metodológico & 71,308 & $-43,386$ & $-14,676$ & $-15,965$ & $-4,667$ & 23,449 & $-80,553$ & 83,168 \\
\hline Dívida externa - outros ajustes & -341 & 15,799 & 6,464 & $-1,082$ & 2,847 & $-2,516$ & $-26,404$ & 10,880 \\
\hline Reconhecimento de dívidas & 6,694 & 605 & 6,514 & 3,262 & -375 & -630 & 135 & -345 \\
\hline Privatizações & $-3,637$ & 0 & -753 & -954 & $-2,049$ & $-1,265$ & -767 & $-3,217$ \\
\hline PIB acumulado em doze meses - valorizado & $1,477,822$ & $1,699,948$ & $1,941,498$ & $2,147,239$ & $2,369,484$ & $2,661,344$ & $3,004,881$ & $3,143,015$ \\
\hline Dívida líquida total - saldo (\%PIB) & 60.6 & 54.9 & 50.6 & 48.2 & 47.0 & 45.1 & 38.4 & 42.8 \\
\hline Dívida líquida - var. ac. ano & 8.4 & -5.7 & -4.3 & -2.4 & -1.3 & -1.8 & -6.7 & 4.4 \\
\hline Fatores condicionantes: & 14.6 & 2.2 & 2.5 & 2.5 & 3.3 & 3.3 & -1.6 & 6.1 \\
\hline NFSP & 4.4 & 5.1 & 2.8 & 3.4 & 3.5 & 2.7 & 1.9 & 3.3 \\
\hline Primário & -3.2 & -3.3 & -3.8 & -3.9 & -3.2 & -3.4 & -3.5 & -2.1 \\
\hline Juros nominais & 7.6 & 8.5 & 6.6 & 7.3 & 6.8 & 6.1 & 5.4 & 5.4 \\
\hline Ajuste cambial & 10.0 & -3.9 & -0.9 & -1.0 & -0.3 & 0.8 & -2.6 & 2.5 \\
\hline Dívida mobil. interna indexada ao câmbio & 5.2 & -1.3 & -0.2 & -0.2 & -0.1 & -0.1 & 0.1 & -0.1 \\
\hline Dívida externa - metodológico & 4.8 & -2.6 & -0.8 & -0.7 & -0.2 & 0.9 & -2.7 & 2.6 \\
\hline Dívida externa - outros ajustes & 0.0 & 0.9 & 0.3 & -0.1 & 0.1 & -0.1 & -0.9 & 0.3 \\
\hline Reconhecimento de dívidas & 0.5 & 0.0 & 0.3 & 0.2 & 0.0 & 0.0 & 0.0 & 0.0 \\
\hline Privatizações & -0.2 & 0.0 & 0.0 & 0.0 & -0.1 & 0.0 & 0.0 & -0.1 \\
\hline Efeito do crescimento do PIB sobre a dívida & -6.2 & -7.9 & -6.8 & -4.8 & -4.5 & -5.1 & -5.2 & -1.7 \\
\hline
\end{tabular}

Fonte: Banco Central

quitar os débitos que assumiu dos estados e municípios (dívidas mobiliárias, dívidas contratuais e obrigações junto a bancos).

${ }^{36}$ Ainda por essas razões, hoje em dia, muitos economistas, ao analisarem as contas públicas, prestam grande atenção à dívida bruta. 


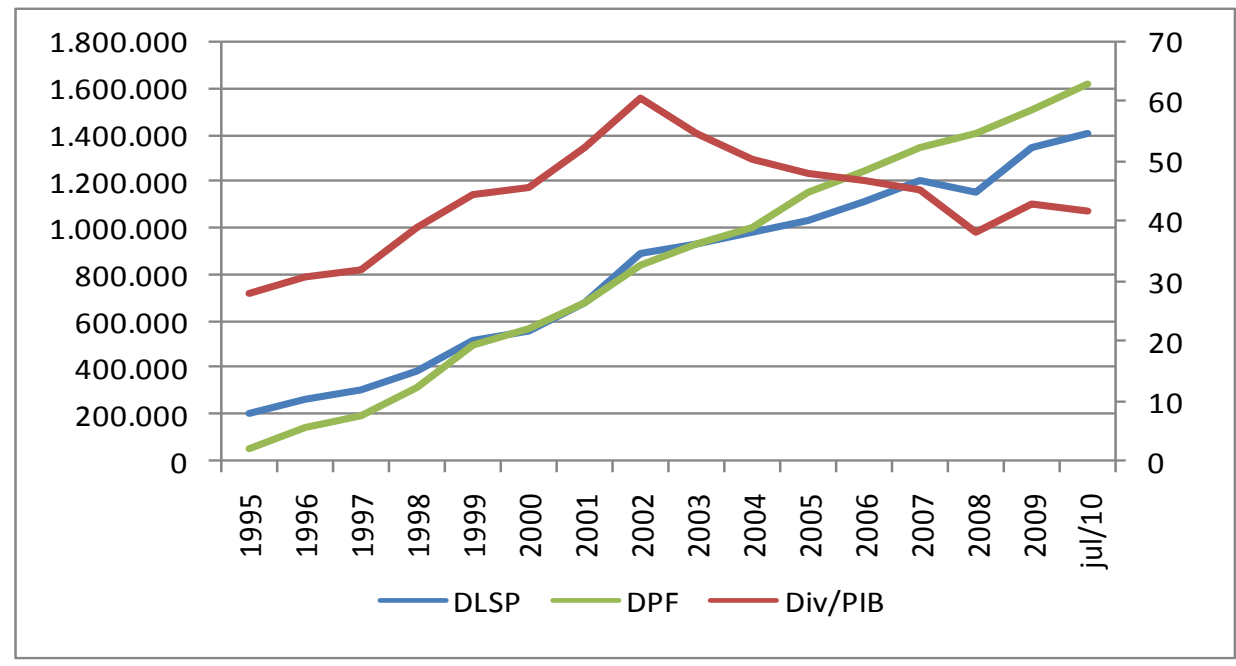

Gráfico 3 - Dívida/PIB, DLSP e DPF no Brasil - 1997 a 2010

Fonte de dados: Ipeadata e STN

Ainda deve ser mencionada, em relação ao estoque da dívida, a mudança significativa em relação à distribuição da DPF entre dívida interna e dívida externa, ao longo dos últimos anos. Esse fato pode ser visualizado no Gráfico 4, que mostra que, atualmente, a parcela de dívida interna já alcança quase 95\%. Por fim, a Tabela 4 resume os principais dados sobre a evolução do estoque da dívida ao longo dos últimos anos.

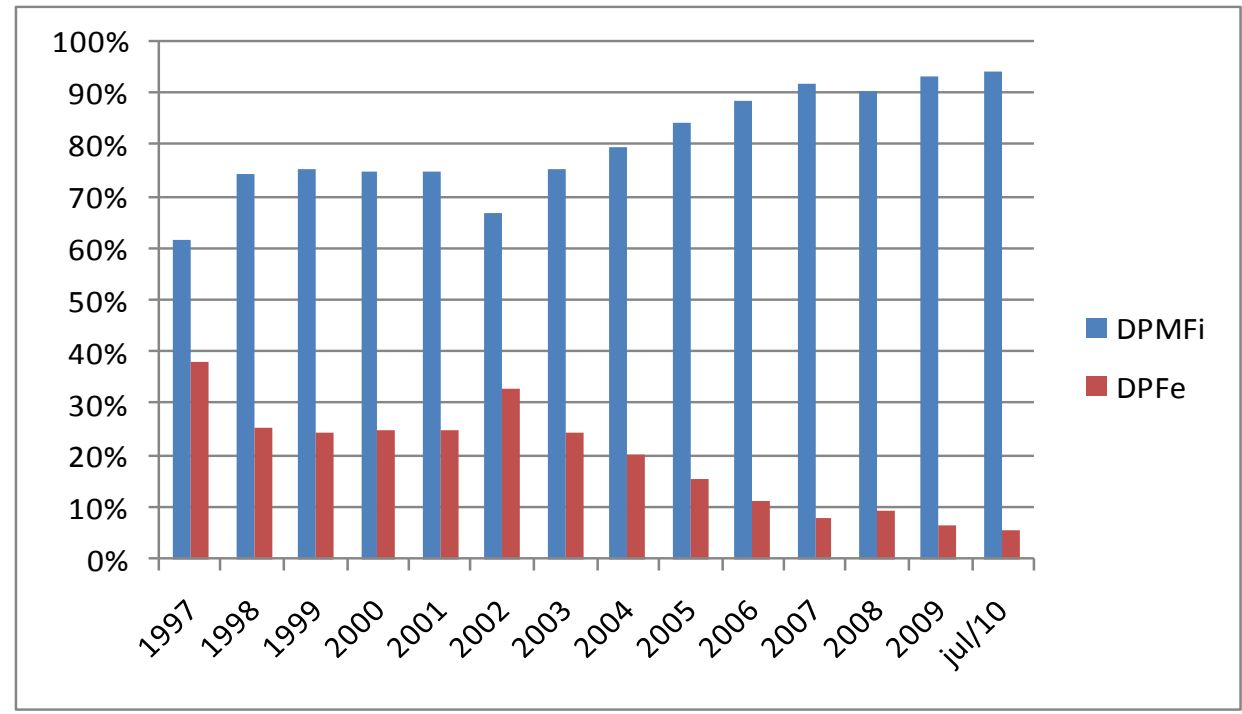

Gráfico 4 - Dívida Interna x Dívida Externa - 1997 a 2010 Fonte de dados: STN 
Tabela 4 - Evolução da Dívida Pública - Diferentes conceitos - 1997 a 2010

\begin{tabular}{|c|c|c|c|c|c|c|c|c|c|c|c|}
\hline \multirow[t]{2}{*}{ Período } & DLSP & $\mathrm{D} / \mathrm{Y}$ & DPMFi & DPFe & DPF & Período & DLSP & $D / Y$ & DPMFi & DPFe & DPF \\
\hline & $\mathrm{R} \$ \mathrm{Mi}$ & $\%$ & $\mathrm{R} \$ \mathrm{Mi}$ & $\mathrm{R} \$ \mathrm{Mi}$ & $\mathrm{R} \$ \mathrm{Mi}$ & & \%a.a. & \%a.a. & \%a.a. & \%a.a. & \%a.a. \\
\hline 1997 & 308,426 & 31.8 & 118,524 & 72,910 & 191,434 & 1997 & $14.6 \%$ & $3.6 \%$ & $-19.4 \%$ & - & $30.1 \%$ \\
\hline 1998 & 385,870 & 38.9 & 238,902 & 81,431 & 320,333 & 1998 & $25.1 \%$ & $22.3 \%$ & $101.6 \%$ & $11.7 \%$ & $67.3 \%$ \\
\hline 1999 & 516,579 & 44.5 & 376,966 & 122,088 & 499,054 & 1999 & $33.9 \%$ & $14.4 \%$ & $57.8 \%$ & $49.9 \%$ & $55.8 \%$ \\
\hline 2000 & 563,163 & 45.5 & 427,090 & 142,794 & 569,884 & 2000 & $9.0 \%$ & $2.3 \%$ & $13.3 \%$ & $17.0 \%$ & $14.2 \%$ \\
\hline 2001 & 680,078 & 52.2 & 505,989 & 169,384 & 675,373 & 2001 & $20.8 \%$ & $14.7 \%$ & $18.5 \%$ & $18.6 \%$ & $18.5 \%$ \\
\hline 2002 & 896,096 & 60.6 & 562,713 & 274,558 & 837,271 & 2002 & $31.8 \%$ & $16.1 \%$ & $11.2 \%$ & $62.1 \%$ & $24.0 \%$ \\
\hline 2003 & 933,630 & 54.9 & 703,320 & 226,053 & 929,373 & 2003 & $4.2 \%$ & $-9.4 \%$ & $25.0 \%$ & $-17.7 \%$ & $11.0 \%$ \\
\hline 2004 & 981,973 & 50.6 & 799,179 & 203,943 & $1,003,122$ & 2004 & $5.2 \%$ & $-7.9 \%$ & $13.6 \%$ & $-9.8 \%$ & $7.9 \%$ \\
\hline 2005 & $1,035,278$ & 48.2 & 976,439 & 177,474 & $1,153,913$ & 2005 & $5.4 \%$ & $-4.7 \%$ & $22.2 \%$ & $-13.0 \%$ & $15.0 \%$ \\
\hline 2006 & $1,112,701$ & 47.0 & $1,100,960$ & 143,455 & $1,244,414$ & 2006 & $7.5 \%$ & $-2.6 \%$ & $12.8 \%$ & $-19.2 \%$ & $7.8 \%$ \\
\hline 2007 & $1,200,799$ & 45.1 & $1,236,540$ & 108,884 & $1,345,425$ & 2007 & $7.9 \%$ & $-3.9 \%$ & $12.3 \%$ & $-24.1 \%$ & $8.1 \%$ \\
\hline 2008 & $1,153,631$ & 38.4 & $1,275,081$ & 132,512 & $1,407,594$ & 2008 & $-3.9 \%$ & $-14.9 \%$ & $3.1 \%$ & $21.7 \%$ & $4.6 \%$ \\
\hline 2009 & $1,345,325$ & 42.8 & $1,410,878$ & 98,974 & $1,509,852$ & 2009 & $16.6 \%$ & $11.5 \%$ & $10.7 \%$ & $-25.3 \%$ & $7.3 \%$ \\
\hline Jul-10 & $1,406,626$ & 41.7 & $1,523,388$ & 94,436 & $1,617,825$ & Jul-10 & $4.6 \%$ & $-2.6 \%$ & $8.0 \%$ & $-4.6 \%$ & $7.2 \%$ \\
\hline
\end{tabular}

Fonte: Ipeadata e STN

\subsection{Composição}

O Gráfico 5 nos mostra como se comportou a composição da DPMFi por indexador desde 1994. Os títulos indexados ao câmbio iniciaram o Plano Real com 12\% de participação e foram diminuindo, atingindo 5,3\% em dezembro de 1995. Em 1997, essa tendência de queda se inverteu, sendo que a alta se intensificou a partir de outubro, na medida em que a situação externa se deteriorava, em razão da crise asiática. Em janeiro de 1999, mês do abandono da âncora cambial, culminando com uma desvalorização do real, a parcela da dívida indexada em moeda estrangeira cresceu quase $50 \%$, passando de $20,7 \%$ pra $29,7 \%$. A partir daí, essa parcela seguiu de maneira mais ou menos estável, em uma leve tendência de queda. Ao final de 2001, com a deterioração do cenário externo (desaceleração norte-americana, atentados terroristas e crise argentina), a participação dos títulos cambiais novamente teve um salto, atingindo 32,9\% em outubro. De lá para cá, no entanto, essa parcela foi caindo sucessivamente, sendo que em dezembro de 2004 ela já estava em 5,2\%. Ressalta-se que desde outubro de 2006 ela está abaixo de 2\%, sendo que na última observação, para julho de 2010, ela atingiu $0,7 \%$. 


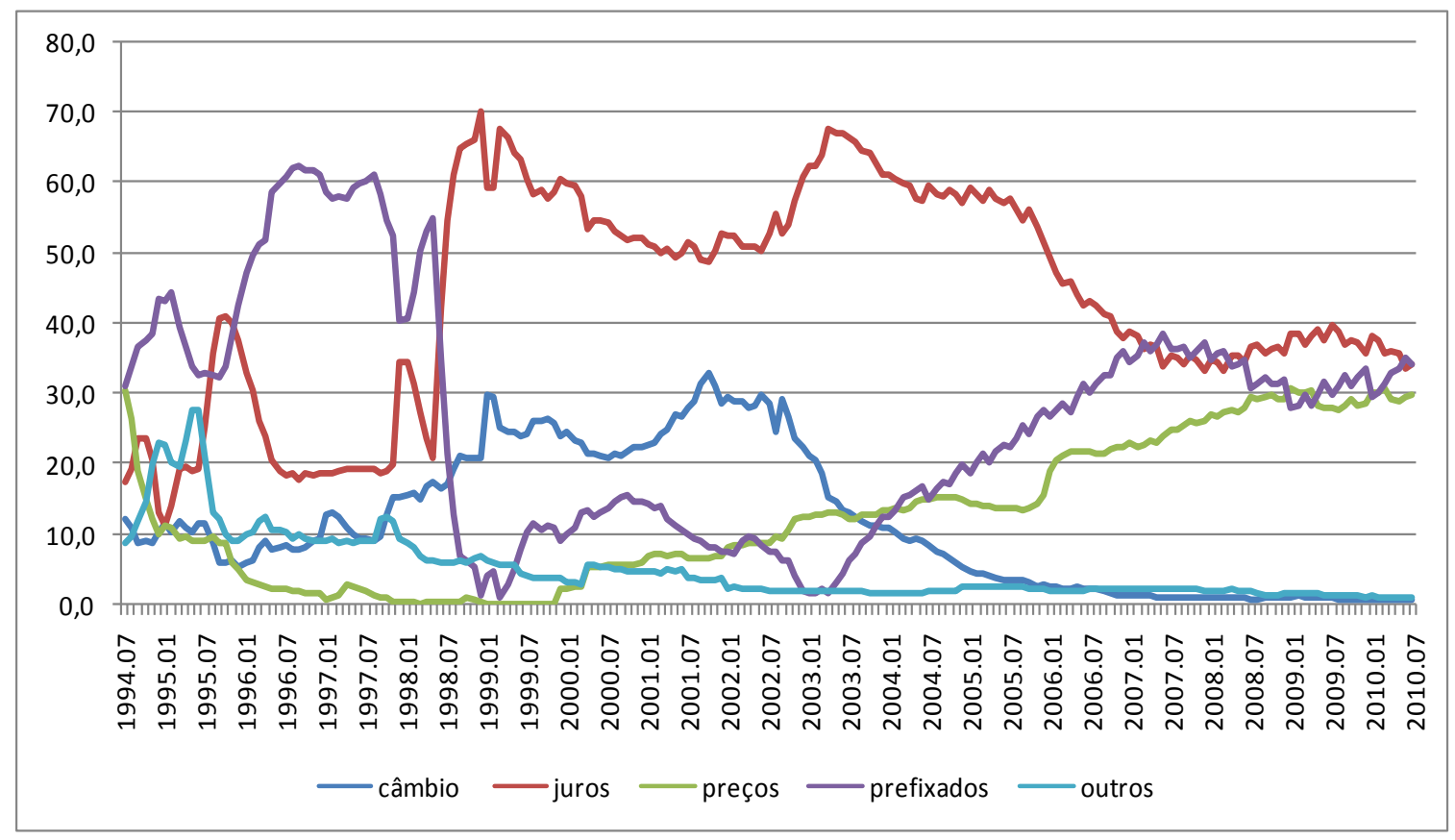

\section{Gráfico 5 - Títulos públicos federais em poder do público (DPMFi) - Participação por indexador - 1994/07 a 2010/07 \\ Fonte de dados: BC e STN.}

Os títulos indexados a índices de preços, por sua vez, começaram o Plano Real com uma parcela de $30 \%$ de participação. Rapidamente, no entanto, essa parcela decresceu, atingindo menos de $10 \%$ já em março de 1995. Bevilaqua e Garcia (2002) indicam que essa queda pode ser explicada por uma estratégia antiinflacionária dentro do plano de estabilização em curso o Plano Real, quando qualquer forma de indexação deveria ser evitada. Assim, só no início de 2000 a participação desse indexador voltou a ter importância, quando alcançou 5,6\% em abril. Entre novembro de 2002 e dezembro de 2005 ela oscilou entre $12 \%$ e $16 \%$ e em janeiro de 2006 deu um salto para 19,2\%. Desde então, a tendência sempre foi de alta e ela permaneceu sempre acima dos 20 pontos percentuais, sendo que nos últimos tempos esteve permanentemente na casa dos $30 \%$.

A parcela de títulos indexados aos juros estava na casa dos $20 \%$ em julho de 1994 . Teve uma redução em dezembro de 1994 e nos dois primeiros meses de 1995; porém, depois disso, no contexto da crise do México, subiu bastante, atingindo 41\% em outubro de 1995. Após esse pico, foi caindo, sendo que entre junho de 1996 e novembro de 1997 teve sempre entre $18 \%$ e $20 \%$. Ao final de 1997, no contexto da crise asiática, a parcela sofreu um salto para $34 \%$ e seguiu bastante volátil, alcançando 70\% em dezembro de 1998. Reduziu-se levemente até o início de 2002, para a casa dos 50 pontos, mas voltou a subir no contexto do pânico dos 
mercados em relação ao processo sucessório do Brasil, quando novamente alcançou patamares acima de 60\%. Desde então, sofreu um processo de queda, mais moderado entre o meio de 2003 e o meio de 2005 e mais acentuado até dezembro de 2007, chegando a 33,4\%. Após essa data, a participação foi gradualmente até 40 pontos (pico em julho de 2009), no contexto da crise financeira mundial, voltando também de forma gradual ao patamar de $34 \%$ em julho de 2010 .

Por fim, a parcela de títulos prefixados também oscilou bastante conforme o ambiente econômico durante o período analisado. No início do Plano Real, tal parcela estava em 33,2\%. Subiu consideravelmente até fevereiro de 1995, alcançando 44,4\%. Em seguida, no contexto da crise mexicana, perdeu participação e chegou aos 32,5\% em setembro de 1995. A partir daí, no entanto, se beneficiou do ambiente de estabilização e da queda de títulos indexados a juros e a preços, subindo bastante e permanecendo próxima aos $60 \%$ até setembro de 1997 . A alta volatilidade da economia internacional ao longo do final de 1997 e 1998 não possibilitou a manutenção deste alto patamar. Segundo Roman (2004), o aumento do risco de juros impôs um alto custo de colocação de dívida prefixada no mercado, fazendo com que o governo desse preferência à dívida indexada em juros e câmbio. Assim, a queda da parcela prefixada foi intensa e, em dezembro de 1998, ela respondia somente por 1,7\% da DPF. Após a mudança do regime macroeconômico, ao longo do ano de 1999, ela voltou a subir, atingindo quase $16 \%$ em outubro de 2000. Em seguida, a tendência foi de queda, sendo que esta participação alcançou 1,9\% em janeiro de 2003. Essa queda inicialmente aconteceu no contexto da deterioração do cenário econômico mundial, com a desaceleração americana, os atentados terroristas e a crise argentina. Assim, com a redução do prazo para a emissão de prefixados, o governo priorizou a questão do risco de refinanciamento, emitindo títulos de prazos maiores. $\mathrm{Na}$ medida em que o novo governo determinava a continuidade das políticas macroeconômicas do governo anterior e as condições da economia internacional melhoravam, a parcela de prefixados começou a subir fortemente. Atingiu quase 39\% em junho de 2007, reduziu gradualmente para a casa dos 30 pontos, no contexto da crise financeira mundial, e hoje está em 34\% do total da DPF.

Assim, em relação à composição da DPMFi e da DPF, os dados mostram a estratégia adotadas pelo Tesouro nos últimos anos: a redução da parcela de títulos indexados à taxa Selic e ao câmbio, concomitante ao aumento de participação dos títulos prefixados e indexados aos preços. Nos próximos capítulos veremos alguns trabalhos que deram respaldo a 
essa estratégia e formularemos um modelo para verificar se o Tesouro deve continuar perseguindo essa composição.

\subsection{Prazo}

Analisando o prazo médio da dívida pública mobiliária federal interna, pelo Gráfico 6 percebemos que ele foi bem baixo até o ano de 1999. A partir daí, ele apresentou uma melhora considerável, subindo até 2001. Já no ano de 2002, ele entra em uma fase de queda até 2005. Os documentos do Tesouro Nacional explicam essa queda a partir de 2003 por seu insucesso na emissão planejada de $\mathrm{CVS}^{37}$, títulos de longo prazo. Somado a esse fator, tem-se também o aumento considerável nas emissões de títulos prefixados, que apresentam um prazo menor, afetando negativamente o prazo médio da DPMFi (Gráf. 7).

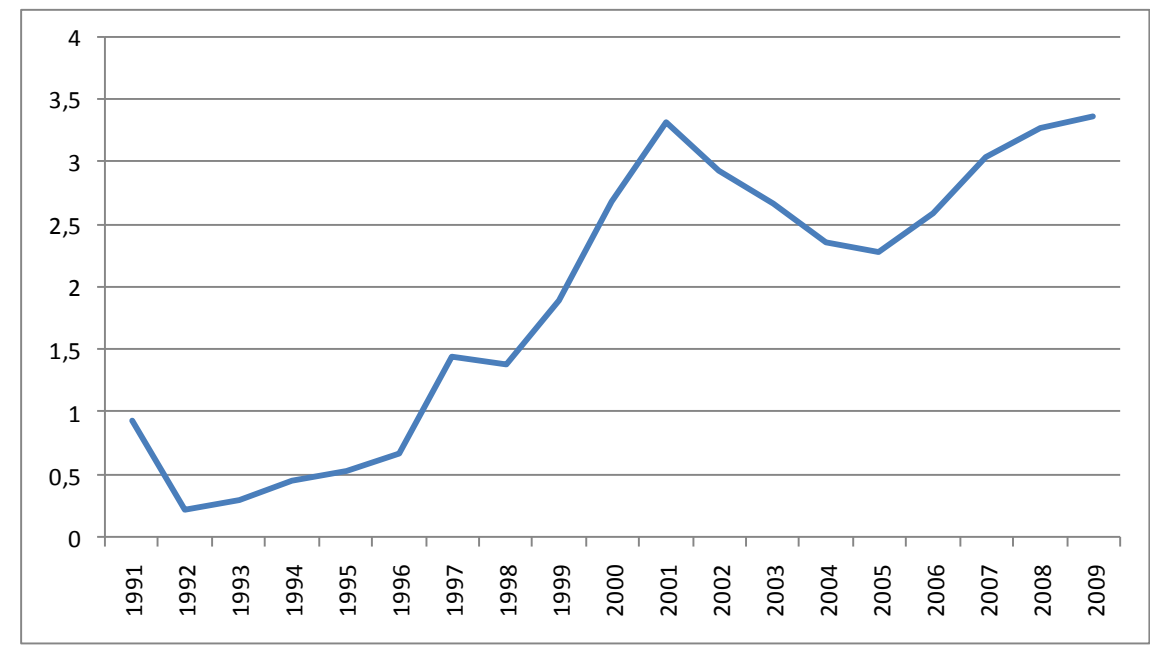

Gráfico 6 - Prazo Médio da DPMFi (em anos) - 1991 a 2009

Fonte de dados: STN.

A partir de 2006, o prazo médio inicia novamente uma fase de alta, explicada tanto pela Lei número 11.312, que concedeu isenção do Imposto de Renda para não-residentes sobre os ganhos obtidos com investimentos na DPMFi, quanto pela maior emissão de títulos indexados aos preços, que possuem um prazo maior. Além disso, o Tesouro acentuou a política de troca de títulos mais curtos por títulos mais longos. Ainda foi importante nessa fase o aumento dos prazos de emissão de títulos prefixados, que contribuíram para o aumento do prazo médio do estoque de prefixados na DPMFi (Gráf. 8).

\footnotetext{
${ }^{37}$ Os CVS são títulos emitidos pelo Tesouro Nacional, relativos à renegociação das dívidas advindas do Fundo de Compensação de Variações Salariais - FCVS, remanescentes da liquidação de contratos de financiamento habitacional do antigo Banco Nacional de Habitação (BNH).
} 
É importante atentar-se ao prazo médio verificado para a DPMFi de 1991 até o ano de 1996, quando ele esteve sempre abaixo de um ano. Com um prazo desse tamanho, é grande a dificuldade enfrentada pelo gestor da dívida, pois o risco de refinanciamento fica muito maior. Logo, ele acaba tendo que priorizar o alongamento, em detrimento de títulos prefixados (que têm o prazo ainda menor ou um prêmio bastante elevado). Esse ponto é fundamental, pois demonstra as limitações condicionadas pelo mercado a uma administração ativa da dívida pública brasileira em tempos remotos.

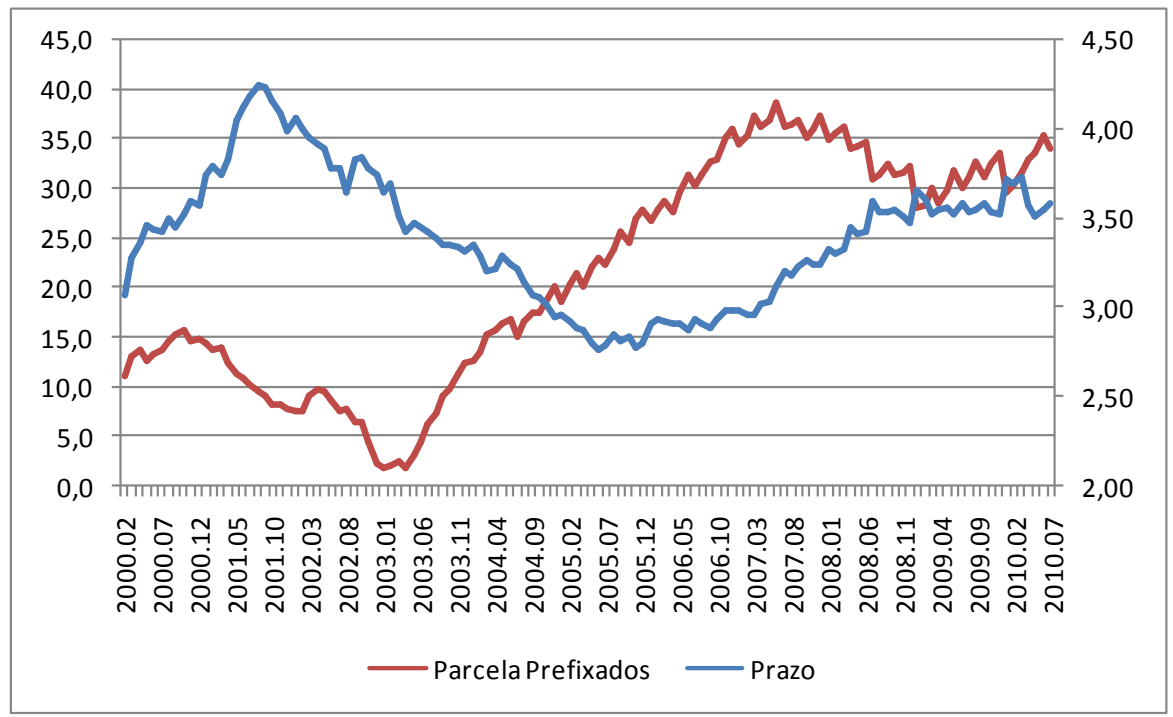

Gráfico 7 - Prazo Médio DPMFi x Parcela de títulos prefixados na DPMFi - 2000 a 2010 Fonte de dados: STN

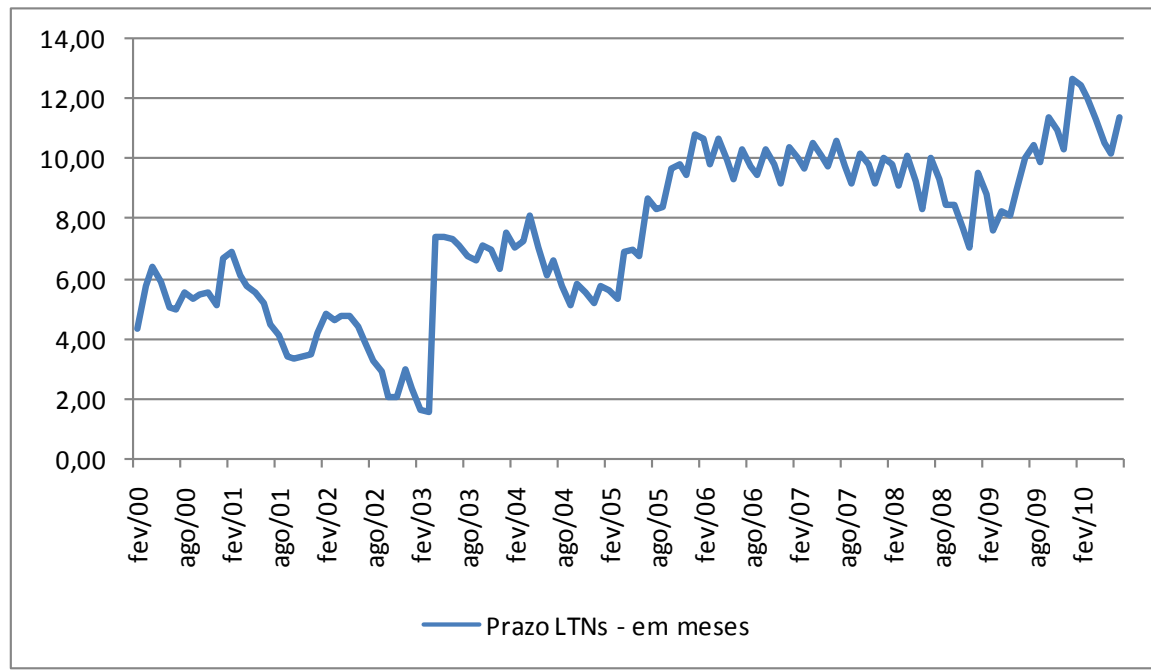

Gráfico 8 - Prazo Médio do Estoque de LTNs - 2000 a 2010

Fonte de dados: STN 
Em relação ao prazo, ainda temos um indicador bastante utilizado pelo Tesouro, que quantifica melhor o risco de refinanciamento (rolagem), que é o percentual vincendo em 12 meses. O Gráfico 9 mostra a evolução desse indicador, que segue de perto a oscilação verificada no prazo médio.

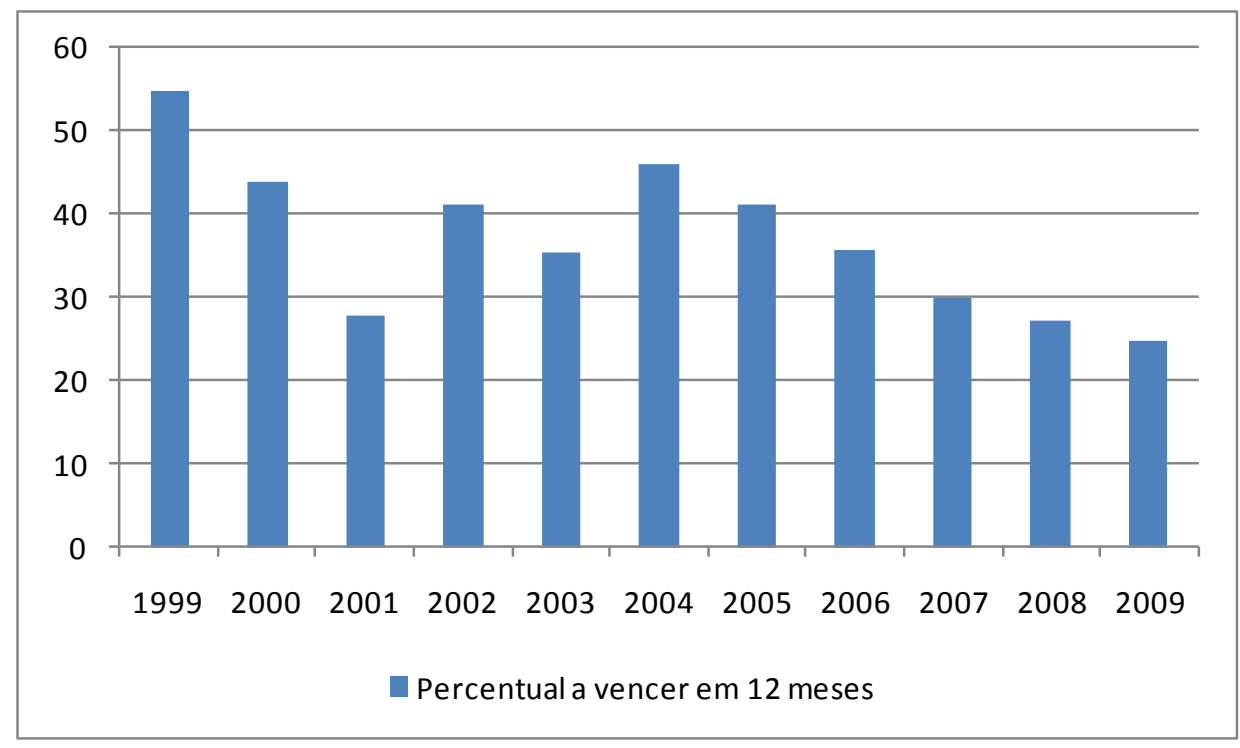

Gráfico 9 - Títulos Federais em poder do público a vencer em 12 meses (\%) - DPMFi 1999 a 2009

Fonte de dados: Ipeadata e STN

\subsection{PAF 2010}

Vimos, no capítulo 1, que o PAF é um dos documentos elaborados pelo Tesouro para dar maior transparência à gestão da dívida pública no país. Assim, tendo exposto a evolução dos principais indicadores nos últimos anos, é interessante apresentar as diretrizes contidas no PAF 2010: (i) aumento do prazo médio do estoque, (ii) suavização da estrutura de vencimentos, (iii) substituição gradual dos títulos remunerados pela Selic por títulos com rentabilidade prefixada ou vinculada a índice de preços, (iv) aperfeiçoamento do perfil da dívida pública federal externa (DPFe) por meio de emissões de títulos com prazos de referências, programa de resgate antecipado e operações estruturadas; (v) incentivo ao desenvolvimento da estrutura a termo das taxas de juros para títulos públicos federais nos mercados interno e externo e (vi) ampliação da base de investidores. (PAF, 2010).

A partir dessas diretrizes, o Tesouro estabelece as metas para a dívida pública federal. As metas do PAF 2010 são apresentadas na Tabela 5. 
Tabela 5 - Metas da Dívida Pública Federal para 2010

\begin{tabular}{l|c|c|c}
\hline \multirow{2}{*}{ INDICADORES } & \multirow{2}{*}{$\mathbf{2 0 0 9}$} & \multicolumn{2}{c}{2010} \\
\cline { 2 - 4 } & & Mínimo & Máximo \\
\hline Estoque (R\$ Bilhões) & 1497.4 & 1600.0 & 1730.0 \\
Composição (\%) & & & \\
Prefixados & 32.2 & 31.0 & 37.0 \\
Índice de Preços & 26.7 & 24.0 & 28.0 \\
Selic & 33.4 & 30.0 & 34.0 \\
Câmbio & 6.6 & 5.0 & 8.0 \\
Demais & 1.1 & 0.0 & 1.0 \\
Estrutura de Vencimentos & & & \\
Prazo Médio (Anos) & 3.5 & 3.4 & 3.7 \\
\% Vincendo em 12 meses & 23.6 & 24.0 & 28.0 \\
\hline
\end{tabular}

Fonte: PAF (2010)

\subsection{Conclusões}

Neste capítulo, procurou-se fazer uma breve exposição da situação do gerenciamento da dívida pública brasileira nos últimos anos. Foram apresentados alguns dados relativos à evolução da DLSP e da relação Dívida/PIB, como também à composição e prazo da dívida brasileira. Além de ter expor a situação da dívida pública brasileira atualmente, o capítulo foi importante pelo fato de evidenciar como era difícil a tarefa de administrar a dívida em tempos remotos. Vimos que em determinados momentos, o Tesouro não tinha alternativas, a não ser emitir títulos de prazo muito curto ou indexar a dívida em ativos mais voláteis, como juros e câmbio. Grande parte dessa dificuldade era causada por um risco de juros extremamente alto, em um contexto de fragilidade fiscal e vulnerabilidade externa da economia brasileira. Isso sem contar no período anterior ao Plano Real, onde em função da alta inflação, o processo era ainda mais difícil. Ressalta-se ainda que vários saltos na relação Dívida/PIB ocorreram em virtude da volatilidade dos indexadores em momentos de turbulência, como no início de 1999 e durante o ano de 2002.

Ao longo do período estudado, pudemos observar que a estrutura da dívida foi evoluindo para um perfil diferente daquele observado no passado. A estratégia adotada pelo Tesouro passou a priorizar a dívida prefixada e indexada aos preços, em detrimento de títulos indexados ao 
câmbio e à taxa de juros. Além disso, ela buscou o alongamento dos prazos.

No próximo capítulo, apresenta-se a literatura empírica sobre a administração ideal da dívida pública, baseada em modelos que procuraram determinar uma composição ideal para a dívida brasileira. Em seguida, seguindo essa literatura, realiza-se um estudo empírico que busca estudar estratégias eficientes para a gestão da dívida pública brasileira. 


\section{BUSCANDO UMA ESTRATÉGIA PARA A GESTÃO DA DÍVIDA PÚBLICA}

Após terem sido expostas as questões teóricas fundamentais sobre a gestão da dívida pública, bem como algumas definições conceituais para o Brasil, no primeiro capítulo, e ter sido apresentada a evolução dos principais indicadores relativos à dívida pública brasileira, no capítulo 2, pretende-se, neste terceiro capítulo, apresentar os principais trabalhos que procuraram indicar composições eficientes para a dívida pública brasileira.

\subsection{Revisão da Literatura}

Bevilaqua e Garcia (2002) fazem uma análise qualitativa a respeito da gestão da dívida pública brasileira $^{38}$. Após simulações para a evolução da razão Dívida/PIB de 1998 até 2002, em diferentes cenários, eles concluem que, mesmo em condições macroeconômicas favoráveis, a evolução deste indicador continuaria sendo preocupante nos anos seguintes. Assim, a gestão da dívida teria um importante papel para amenizar as conseqüências de um alto endividamento público.

Em relação aos instrumentos, seria esperada uma redução dos títulos indexados ao câmbio. O problema da escolha entre dívida nominal (prefixada) ou indexada é dividido em duas partes: na primeira escolher-se-ia a proporção de cada um deles no total da dívida e, em seguida, escolher-se-ia os indexadores para a parcela indexada ${ }^{39}$.

Uma prioridade central seria alongar a dívida, obviamente tentando fazê-lo pelo menor custo possível. Assim, em relação à primeira parte do problema, os autores defendem a emissão de dívida indexada, pois o prêmio de risco para títulos nominais mais longos seria anormalmente alto. A recomendação básica seria, portanto, emitir dívida nominal com a maior maturidade possível, sem tornar a curva de juros muito inclinada no final.

A segunda parte da pergunta seria o quanto de cada indexador deveria ser emitido. Indexados em moeda estrangeira iriam cair, até porque essa seria uma recomendação do FMI no contexto de sua ajuda ao Brasil. Sob o regime de metas de inflação, o uso de títulos indexados

\footnotetext{
${ }^{38}$ A publicação do artigo é de 2002, mas as simulações e análises são feitas em 1998, tendo como horizonte o fim de 2002.

${ }^{39}$ Reforça-se aqui que a análise foi feita apenas de modo qualitativo, além de não ter envolvido nenhum modelo ou metodologia mais formal.
} 
à taxa Selic reduziria a credibilidade e a reputação da política monetária. Desta maneira, a recomendação seria a redução da emissão de títulos indexados ao câmbio e à taxa Selic.

Logo, para efetuar o alongamento do prazo, o mais aconselhável seria a emissão de títulos indexados aos preços. O ponto negativo deste título seria seu efeito inflacionário. Na ocasião, a parcela de dívida indexada aos preços era muito baixa, resultado, segundo os autores, das decisões no âmbito do Plano Real, quando se acreditou que esses títulos poderiam alimentar a inflação. Assim, Bevilaqua e Garcia (2002) sugeriram a reversão desta decisão, isto é, restabelecer a emissão destes títulos, aproveitando uma demanda reprimida em fundos de pensão, seguradoras e outros agentes que possuem passivos de longo prazo e correlacionados com os níveis de preço.

Na seqüência do Plano Real, por fim, quando as metas de crescimento e de um ambiente nãoinflacionário fossem atingidas, a estrutura de dívida naturalmente poderia migrar para maior emissão de divida nominal, incluindo de longo prazo.

Goldfajn (2000) e Goldfajn e de Paula (1999) estudam a composição ótima para a dívida pública nacional, no contexto da minimização do risco orçamentário. Utilizam um modelo teórico de dois períodos, em que o governo busca minimizar uma função objetivo que representa as expectativas das distorções tributárias e inflacionárias, conforme a disposição abaixo:

$$
E\left[A \cdot{\frac{\tau^{2}}{2}}^{2}+\frac{\pi^{2}}{2}\right]
$$

sendo que $\mathrm{A}>0, \tau$ são os tributos, $\pi$ inflação e $E$ a esperança da função.

Para realizar esta minimização, os autores definem três instrumentos a disposição da autoridade fiscal: (i) títulos nominais (prefixados), cuja taxa de retorno é igual a $i$, e tem, portanto, o retorno real realizado igual a $(1+i) /(1+\pi)$; (ii) títulos indexados à inflação, pagando uma taxa igual a $r$ mais a taxa de inflação realizada e (iii) títulos denominados em moeda estrangeira, que pagam a taxa de juros externa, $i *$, mais a taxa de depreciação $e$, e, desta maneira, apresentam um retorno real em moeda nacional igual a $(1+i *)(1+e) /(1+\pi)$. 
Assumindo a hipótese de neutralidade ao risco por parte dos investidores, supõe-se que a taxa de juros nominal demandada se iguala a taxa real mais a taxa de inflação esperada da seguinte forma:

$(1+i)=(1+r)\left(1+\pi^{e}\right)$

Os autores ainda fazem outras hipóteses para resolver o modelo, como a paridade descoberta de juros $\left((1+i)=\left(1+e^{e}\right)\left(1+i^{*}\right)\right)$ e o estabelecimento de uma equação do mercado monetário para governar a taxa de inflação: $\pi=m+v$, onde $m$ é o crescimento da oferta monetária e $v$ um choque de velocidade fora do controle do governo, com as propriedades de um ruído branco.

Assim, com investidores racionais, ter-se-ia, em equilíbrio a seguinte igualdade:

$\pi^{e}=E[\pi]=m$

Por fim, usando a paridade descoberta da taxa de juros e a taxa de retorno requerida pelos agentes e linearizando a restrição orçamentária do governo, obtém-se:

$\tilde{\tau}=\tilde{G}+(1+r) B\left[1-\theta\left(\tilde{\pi}-\pi^{e}\right)-\theta^{*}\left(\tilde{q}-q^{e}\right)\right]$

onde $\theta$ e $\theta^{*}$ são as proporções em dívida nominal e em moeda estrangeira, $B$ é o nível total da dívida, $G$ são os gastos do governo e $\tilde{q}=\tilde{\pi}-\tilde{e}$.

Os autores resolvem o modelo ${ }^{40}$ e encontram a solução, sob comprometimento ${ }^{41}$, para as proporções de dívida nominal e dívida em moeda estrangeira ${ }^{42}$ :

\footnotetext{
${ }^{40}$ Minimizam (3.1) sujeito à (3.3) e (3.4).

${ }^{41}$ A solução de comprometimento é aquela em que o governo em $t=1$ força o comprometimento do governo em $t=2$ em suas decisões.

${ }^{42}$ Adicionalmente, esta solução tem o crescimento ótimo da oferta monetária igual a zero. Para maiores detalhes, consultar Goldfajn (2000).
} 
$\theta=\frac{\sigma_{g \pi} \sigma_{q}^{2}-\sigma_{g q} \sigma_{\pi q}^{2}}{B\left[\sigma_{\pi}^{2} \sigma_{q}^{2}+\left(\sigma_{\pi q}\right)^{2}\right]} \quad e \quad \theta^{*}=\frac{\sigma_{g q}}{B \sigma_{q}^{2}}-\frac{\sigma_{\pi q} \theta}{\sigma_{q}^{2}}$

onde $\sigma$ denota a covariância entre as variáveis dispostas no subscrito. A partir desses resultados, Goldfajn (2000) lista as principais implicações fornecidas pelo modelo:

- $\quad$ A proporção de dívida nominal deve diminuir com o nível total da dívida;

- $\quad$ A proporção de dívida nominal deve ser negativamente relacionada com a variância da inflação;

- A proporção de dívida nominal deveria aumentar quando a covariância da inflação com gastos é maior;

- A proporção da dívida em moeda estrangeira deve aumentar quando a covariância entre câmbio real e gastos é maior;

- $\quad$ A proporção da dívida em moeda estrangeira deve ser negativamente relacionada com a variância do câmbio real.

Como exercício empírico, Goldfajn e de Paula (1999) resolvem trabalhar essas implicações com os dados para o Brasil. As covariâncias e desvios-padrão foram obtidos através de um Vetor Auto-Regressivo (VAR), que envolveu as variáveis taxa de inflação, gastos reais do Tesouro (excluindo-se os juros da dívida), câmbio real efetivo e produto (através do IPFIBGE como proxy). Goldfajn e de Paula (1999) argumentaram que a obtenção das covariâncias e desvios-padrão através dos resíduos de um VAR seria um procedimento melhor do que medidas de correlação simples, pois quantificaria melhor as inovações não esperadas pelos agentes envolvidos.

Após a estimação do VAR, os resultados indicaram que:

- A volatilidade da inflação estava diminuindo, enquanto a volatilidade cambial estava aumentando (devido à adoção do câmbio flutuante): tais fatos sugeririam uma composição crescente em títulos prefixados, longos, em moeda nacional.

- A correlação entre gastos e inflação estava crescente, sugerindo esses mesmos tipos de títulos. Dessa maneira, poder-se-ia diminuir a volatilidade do resultado nominal.

- A correlação entre câmbio real e gastos foi positiva entre 1990 e 1994 e 1995 e 1998, 
porém se tornou negativa em 1999. Caso continuasse com essa tendência, seria um fator para justificar o aumento da dívida indexada em moeda estrangeira.

De maneira geral, portanto, em relação à consideração sobre volatilidade orçamentária, os resultados sugeriram o alongamento da dívida em títulos prefixados em moeda nacional, com atenção para a correlação negativa entre câmbio e gastos, que justificaria a indexação de uma parcela da dívida ao câmbio. ${ }^{43}$

Giavazzi e Missale (2004) realizaram um estudo para derivar a composição ótima da dívida pública brasileira. O modelo foi desenvolvido sob a hipótese de que o principal objetivo da gestão da dívida seria estabilizar a relação Dívida/PIB e, portanto, reduzir a probabilidade de uma crise de dívida no país. Assim, eles estudaram o impacto relativo entre custo esperado e risco dos diferentes títulos, preocupando-se com a minimização do risco.

Assim, para os autores, uma crise de dívida ocorreria quando

$B_{t+1}^{T}-A_{t+1}+X>B_{t}$

onde $B_{t}$ expressa a dívida/PIB em $t, B_{t+1}^{T}$ é a dívida/PIB que prevaleceria em $t+1$ caso não ocorresse o ajuste fiscal, e $A_{t+1}-X$ denota esse ajuste, sendo o primeiro termo o ajuste fiscal esperado e o segundo termo um componente de incerteza a respeito do ajustamento ${ }^{44}$.

O termo $B_{t+1}^{T}$ é definido como $B_{t+1}^{T}=\Delta B_{t+1}^{T}+B_{t}$, sendo

$\Delta B_{t+1}^{T}=I_{t+1} B_{t}+\Delta e_{\mathrm{t}+1} q B_{t}-S_{t+1}^{T}-\left(\Delta y_{t+1}+\pi_{t+1}\right) B_{t}$

onde $I_{t+1} B_{t}$ são os juros nominais, $e_{\mathrm{t}+1}$ é o $\log$ da taxa de câmbio nominal, $q$ é a fração da dívida denominada em dólar, $S_{t+1}^{T}$ é a tendência do superávit primário, $y_{t+1}$ é o log do produto e $\pi_{t+1}$ a taxa de inflação. O pagamento de juros nominais depende dos rendimentos e da parcela de dívida alocada a cada indexador, da seguinte maneira:

$I_{t+1} B_{t}=i_{t+1} s B_{t}+\left(R_{t}^{U S}+R P_{t}\right) q B_{t}+\left(R_{t}^{I}+\pi_{t+1}\right) h B_{t}+R_{t}(1-s-q-h) B_{t}$

\footnotetext{
43 Além disso, considerações teóricas sobre liquidez indicaram a necessidade de concentrar vencimentos. Entretanto, segundos os autores, tais ações seriam as ideais no longo prazo apenas, dado que, durante a transição para uma economia mais estável, outros tradeoffs deveriam ser analisados. Assim, no curto prazo, considerações sobre credibilidade, sinalização e risco de rolagem sugeririam uma transição lenta para uma dívida mais longa, uma emissão maior de dívida cambial e maior cautela ao concentrar vencimentos.

${ }^{44}$ Que poderia ser interpretado como, por exemplo, o reconhecimento de passivos contingentes.
} 
sendo $s$ a parcela de dívida indexada à taxa Selic, $q$ a parcela de dívida denominada em dólar, $h$ a parcela de dívida indexada aos preços, $R_{t}$ a taxa de juros de longo prazo (na qual os títulos prefixados seriam emitidos ${ }^{45}$ ), $R_{t}^{I}$ a taxa de juros real e $R_{t}^{U S}+R P_{t}$ o retorno dos títulos denominados em dólar, sendo o primeiro termo relativo à taxa de juros americana e o segundo o prêmio de risco ${ }^{46}$.

O superávit primário depende das condições cíclicas de produto e da inflação, conforme a seguinte equação:

$S_{t+1}^{T}=E_{t} S_{t+1}^{T}+\eta_{y}\left(y_{t+1}-E_{t} y_{t+1}\right)+\eta_{\pi}\left(\pi_{t+1}-E_{t} \pi_{t+1}\right)$

onde $\eta_{y} \mathrm{e} \eta_{\pi}$ são as semi-elasticidades do orçamento do governo (em relação ao PIB) com relação ao produto e à inflação, respectivamente, e $E_{t}$ é a expectativa condicionada à informação disponível em $t$.

Assim, o governo deve escolher $s, q$ e $h$ de maneira a minimizar a função

$\operatorname{Min} E_{t} \operatorname{Prob}\left[X>A_{t+1}-\Delta B_{t+1}^{T}\right]=\operatorname{Min} E_{t} \int_{A_{t+1}-\Delta B_{t+1}^{T}}^{\infty} \phi(X) d x$

sujeito à (3.7), (3.8) e (3.9). O termo $\phi(X)$ denota a função densidade de probabilidade de $X$.

Derivando (3.10) em relação a $s, q$ e $h$, temos

$$
\begin{aligned}
& E_{t} \phi\left(A_{t+1}-\Delta B_{t+1}^{T}\right)\left[i_{t+1}-R_{t}\right]=0 \\
& E_{t} \phi\left(A_{t+1}-\Delta B_{t+1}^{T}\right)\left[R_{t}^{U S}+R P_{t}+e_{t+1}-e_{t}-R_{t}\right]=0 \\
& E_{t} \phi\left(A_{t+1}-\Delta B_{t+1}^{T}\right)\left[R_{t}^{I}+\pi_{t+1}-R_{t}\right]=0
\end{aligned}
$$

Essas condições de primeira ordem mostram que a estrutura de dívida é ótima apenas quando o aumento da probabilidade do insucesso na estabilização, associada ao custo marginal de emissão de cada tipo de dívida, é igual para todos os instrumentos (indexadores).

O próximo passo seria definir a rentabilidade de cada título, isto é, o custo de cada um para o governo. Isso é feito pela diferença em relação ao título prefixado. Assim, a diferença de rentabilidade entre o custo dos títulos indexados à Selic e os títulos prefixados é:

\footnotetext{
${ }^{45}$ Os autores assumem que todos os títulos tem a maturidade de 1 ano.

${ }^{46} R_{t}^{U S}+R P_{t}$ é uma aproximação para $\left(R_{t}^{U S}+R P_{t}\right)\left(1+\Delta e_{t+1}\right)$.
} 
$i_{t+1}-R_{t}=i_{t+1}-E_{t} i_{t+1}-T P_{t}$

onde $T P_{t}$ é o prêmio de risco dos prefixados. A diferença entre o custo dos títulos denominados em dólar e os títulos prefixados depende da realização da taxa de câmbio:

$R_{t}^{U S}+R P_{t}+e_{t+1}-e_{t}-R_{t}=e_{t+1}-E_{t} e_{t+1}-F P_{t}$

onde $F P_{t}$ é o prêmio do risco relacionado ao câmbio. Por fim, a diferença entre o custo dos títulos indexados aos preços e os títulos prefixados é:

$R_{t}^{I}+\pi_{t+1}-R_{t}=\pi_{t+1}-E_{t} \pi_{t+1}-I P_{t}$

Onde $I P_{t}$ é o prêmio de risco associado à inflação. A diferença entre esses retornos nos permite reescrever as condições de primeira ordem da seguinte maneira:

$E_{t} \phi\left(A_{t+1}-\Delta B_{t+1}^{T}\right)\left(i_{t+1}-E_{t} i_{t+1}\right)=T P_{t} E_{t} \phi\left(A_{t+1}-\Delta B_{t+1}^{T}\right)$

$E_{t} \phi\left(A_{t+1}-\Delta B_{t+1}^{T}\right)\left(e_{t+1}-E_{t} e_{t+1}\right)=F P_{t} E_{t} \phi\left(A_{t+1}-\Delta B_{t+1}^{T}\right)$

$E_{t} \phi\left(A_{t+1}-\Delta B_{t+1}^{T}\right)\left(\pi_{t+1}-E_{t} \pi_{t+1}\right)=I P_{t} E_{t} \phi\left(A_{t+1}-\Delta B_{t+1}^{T}\right)$

Desta maneira, essas equações retratam o tradeoff entre risco e custo esperado que caracterizam a escolha dos diferentes instrumentos. Na margem, portanto, o impacto na probabilidade de estabilização do aumento do risco deve ser igual ao impacto da redução do custo esperado. Assim, o aumento marginal na probabilidade deve ser utilizado para precificar o risco em relação ao custo esperado, encontrando uma combinação ótima ao longo do tradeoff mencionado.

Para derivar uma solução explícita para as parcelas ótimas para cada tipo de dívida, Giavazzi e Missale (2004) especificam a função densidade de probabilidade de $X$ como uma aproximação linear sobre as realizações de $X>0$. Assim, isso implica em uma função de densidade triangular, igual a

$\phi(X)=\frac{\bar{X}-X}{\bar{X}^{2}}$

Onde $X>0$ e $\bar{X}$ é o pior resultado possível do ajustamento fiscal.

Substituindo a equação (3.20) e (3.7) - (3.9) nas condições de primeira ordem (3.17) - (3.19), 
obtêm-se as parcelas ótimas de dívida indexada à taxa Selic $\left(s^{*}\right)$, dívida denominada em dólar $\left(q^{*}\right)$ e dívida indexada aos preços $\left(h^{*}\right)$ :

$$
\begin{aligned}
s^{*}=\frac{\left(\eta_{y}+B_{t}\right)}{B_{t}} & \frac{\operatorname{Cov}\left(y_{t+1} i_{t+1}\right)}{\operatorname{Var}\left(i_{t+1}\right)}+\frac{\left(\eta_{\pi}+B_{t}\right)}{B_{t}} \frac{\operatorname{Cov}\left(\pi_{t+1} i_{t+1}\right)}{\operatorname{Var}\left(i_{t+1}\right)}-q^{*} \frac{\operatorname{Cov}\left(e_{t+1} i_{t+1}\right)}{\operatorname{Var}\left(i_{t+1}\right)} \\
& -h^{*} \frac{\operatorname{Cov}\left(\pi_{t+1} i_{t+1}\right)}{\operatorname{Var}\left(i_{t+1}\right)}+\operatorname{TP} \frac{\sqrt{2 P r}}{1-\sqrt{2 \operatorname{Pr}}} \frac{E_{t}\left(A_{t+1}-\Delta B_{t+1}^{T}\right)}{B_{t} \operatorname{Var}\left(i_{t+1}\right)} \\
q^{*}= & \frac{\left(\eta_{y}+B_{t}\right)}{B_{t}} \frac{\operatorname{Cov}\left(y_{t+1} e_{t+1}\right)}{\operatorname{Var}\left(e_{t+1}\right)}+\frac{\left(\eta_{\pi}+B_{t}\right)}{B_{t}} \frac{\operatorname{Cov}\left(\pi_{t+1} e_{t+1}\right)}{\operatorname{Var}\left(e_{t+1}\right)}-s^{*} \frac{\operatorname{Cov}\left(e_{t+1} i_{t+1}\right)}{\operatorname{Var}\left(e_{t+1}\right)} \\
- & h^{*} \frac{\operatorname{Cov}\left(\pi_{t+1} e_{t+1}\right)}{\operatorname{Var}\left(e_{t+1}\right)}+F P_{t} \frac{\sqrt{2 P r}}{1-\sqrt{2 \operatorname{Pr}}} \frac{E_{t}\left(A_{t+1}-\Delta B_{t+1}^{T}\right)}{B_{t} \operatorname{Var}\left(e_{t+1}\right)} \\
h^{*}= & \frac{\left(\eta_{y}+B_{t}\right)}{B_{t}} \frac{\operatorname{Cov}\left(y_{t+1} \pi_{t+1}\right)}{\operatorname{Var}\left(\pi_{t+1}\right)}+\frac{\left(\eta_{\pi}+B_{t}\right)}{B_{t}}-q^{*} \frac{\operatorname{Cov}\left(e_{t+1} \pi_{t+1}\right)}{\operatorname{Var}\left(\pi_{t+1}\right)}-s^{*} \frac{\operatorname{Cov}\left(\pi_{t+1} i_{t+1}\right)}{\operatorname{Var}\left(\pi_{t+1}\right)} \\
+ & \operatorname{IP} \frac{P_{t} \frac{E_{t}\left(A_{t+1}-\Delta B_{t+1}^{T}\right)}{1-\sqrt{2 P r}}}{B_{t} \operatorname{Var}\left(\pi_{t+1}\right)}
\end{aligned}
$$

onde $\operatorname{Var}($.$) e \operatorname{Cov}($.$) se referem as variâncias e covariâncias condicionais de acordo com a$ informação disponível em $t$ e $\operatorname{Pr}$ é a probabilidade de crise de dívida percebida pelo governo.

Assim, o risco é minimizado quando um instrumento fornece um seguro contra variações no superávit primário e na relação Dívida/PIB, devido a flutuações no produto e inflação, e quando a variância condicional de seu retorno é relativamente baixa. Esse resultado é capturado pelos dois primeiros termos das equações (3.21) - (3.23).

A minimização do risco também depende das variâncias condicionais entre os retornos dos diferentes títulos. Uma covariância positiva entre o retorno de dois indexadores, por exemplo, os tornam substitutos na carteira do governo. Essa relação é capturada pelo terceiro e quarto termo das equações $(3.21)-(3.23)$.

Para chegar a soluções explícitas, os autores calibram alguns parâmetros, como a as semielasticidades e a probabilidade de crise de dívida. Para os prêmios de risco, os autores estimam através dos diferenciais do custo dos diferentes títulos no mercado. Por fim, para resolver o problema de como obter as variâncias e covariâncias condicionais pelos erros de previsão de um ano anterior entre as variáveis macroeconômicas, os autores utilizam três 
métodos alternativos: (i) pesquisas diárias das expectativas, onde os componentes não esperados podem ser obtidos como a diferença entre o realizado e o previsto um ano antes, (ii) um modelo estrutural com expectativas adaptativas, onde os componentes não antecipados são estimados como a função de impulso-resposta acumulada em 12 meses das variáveis a partir de choques de oferta, de demanda e do EMBI spread e (iii) regressões de previsão, onde os componentes não antecipados em um ano são aproximados usando os resíduos das equações de previsão para dados trimestrais.

De maneira geral, os resultados encontrados foram robustos aos diferentes métodos e sugeriram que, para evitar uma crise de dívida, o governo deveria aumentar a participação de títulos prefixados e indexados aos índices de preços e reduzir a participação de títulos indexados à Selic e ao câmbio.

Lopes e Domingos (2004) buscam derivar uma fronteira eficiente para a composição ótima da dívida pública brasileira, a partir de um modelo macro-estrutural, para três diferentes regras de política monetária. A estratégia dos autores é a seguinte: eles simulam a economia através de um modelo adaptado de Ball (1999) (acrescido de uma equação para o risco-país - EMBI), gerando trajetórias para as principais variáveis macroeconômicas (produto, inflação, câmbio e juros). Como as simulações são estocásticas, a economia é simulada várias vezes. Em seguida, para cada estratégia de financiamento da dívida, analisa-se a situação da relação dívida/PIB após o período de simulação, sendo que o retorno é medido pela sua média e o seu risco é medido pelo desvio padrão.

O modelo utilizado é caracterizado pelas seguintes equações, que representam, respectivamente, a curva IS, a curva de Phillips, uma equação para o câmbio, outra para o risco país e a última para a Regra de Juros:

$$
\begin{aligned}
& y=\beta r_{-1}+\delta e_{-1}+\lambda y_{-1}+\varepsilon \\
& \pi=\varsigma \pi_{-1}+\alpha y_{-2}+\gamma\left(e_{-1}-e_{-2}\right)+\eta \\
& e=\chi E m b i+v
\end{aligned}
$$

$E m b i=\kappa E m b i_{-1}+\varpi(\text { Divida } / P I B)_{-1}+v$

$r=\rho r_{-1}+\psi\left(\pi_{-1}-\pi^{*}\right)+\phi y_{-1}$ 
onde y é o hiato do produto, $r$ a taxa de juros, $e$ a taxa de câmbio real, $\pi$ a inflação, Embi o risco-país, $\pi^{*}$ a meta de inflação, $\varepsilon, \eta, v$ são ruídos brancos e o resto são parâmetros a serem estimados.

A dívida/PIB evolui de acordo com o custo de carregamento (endógeno a cada composição de dívida), com o crescimento do produto e com o superávit primário $(S P)$. Os dois últimos são definidos exogenamente como 4,25\% do PIB e 3,5\%, respectivamente, e esta evolução é descrita pela equação abaixo ${ }^{47}$ :

$$
\frac{\text { Divida }}{P I B}=\frac{1+c c}{1+g}\left(\frac{\text { Divida }}{P I B}\right)_{-1}-\frac{S P}{P I B}
$$

A amostra utilizada é trimestral e abrange o período de 1994 a 2003. As estimações foram feitas por MQO (Mínimos Quadrados Ordinários), com a premissa de que as séries eram estacionárias. Outro detalhe importante é que a regra de juros não foi estimada e sim calibrada de três maneiras diferentes, de modo a retratar três diferentes regras monetárias: uma tradicional (com peso dividido entre inflação e produto), uma com peso total na inflação e outra com peso total no produto.

Assim, simulando o comportamento da economia várias vezes, os autores encontram uma distribuição de probabilidades para a relação dívida/PIB para diferentes composições de dívida, podendo derivar daí a análise de risco e retorno e, conseqüentemente, a fronteira eficiente $^{48}$. Esta foi apresentada para cada um dos três modelos e variaram de acordo com a regra de política monetária considerada. Quando esta é a tradicional regra de Taylor, os resultados sugerem que as carteiras eficientes serão compostas principalmente por títulos indexados à taxa de juros e títulos prefixados. Quando a regra de juros é aquela com peso total na inflação, as carteiras eficientes deverão conter uma maior parcela de títulos prefixados e indexados aos preços. A intuição é que o ambiente se torna menos inflacionário e, portanto, o custo do pagamento dos prêmios de títulos indexados à inflação cai bastante. Na mesma direção, o risco desses títulos também decresce, favorecendo a sua emissão pela autoridade fiscal. Por fim, quando a regra de juros coloca todo o peso no produto, as carteiras com maior

\footnotetext{
${ }^{47}$ Onde $g$ é o crescimento, $c c$ é o custo de carregamento e $S P$ o superávit primário. Na simulação, o valor inicial para as variáveis são os últimos observados na amostra, sendo que para a relação Dívida/PIB o valor inicial é de $56 \%$.

${ }^{48}$ A referência clássica para análises de risco e retorno, originando fronteiras eficientes, é Markowitz (1952).
} 
destaque se tornam aquelas formadas por títulos prefixados e títulos indexados à variação cambial.

Desta maneira, os autores concluem que, dependendo da regra monetária seguida pelo Banco Central, altera-se o perfil do endividamento público, implicando em diferentes propriedades de risco e retorno para uma mesma carteira. Notam ainda a presença dos títulos prefixados nas composições ótimas obtidas para todas as três regras. Isso poderia ser em parte explicado pela não incorporação de um prêmio de risco neste ativo, tornando sua emissão mais barata exante. Por último, os autores destacam a necessidade de se incluir outros prazos e um prêmio de risco para o ativo prefixado, como forma de tornar as simulações mais realistas.

O modelo apresentado por Lopes e Domingos (2004) é importante pelo fato de ser uma das primeiras tentativas de construir um benchmark para a gestão da dívida pública brasileira. No entanto, apresenta algumas limitações: (i) a amostra utilizada na estimação foi prejudicada pela mudança de política macroeconômica brasileira, realizada em 1999 e, portanto, no meio do período amostral utilizado, afetando negativamente as estimativas dos parâmetros, (ii) as simulações da economia retornaram razões Dívida/PIB negativas, evidenciando pouca aderência com a realidade, (iii) a tentativa de modelar um feedback entre Dívida e o risco-país é irrealista, já que o risco-país está longe de ser determinado predominantemente pela razão Dívida/PIB ${ }^{49}$. O mesmo pode ser dito em relação à equação do câmbio, que tem como única variável explicativa o risco-país. De qualquer forma, este trabalho é uma referência importante na literatura da composição ótima da dívida pública.

Borges (2006) simula a economia em um modelo macro-estrutural similar ao proposto por Lopes e Domingos (2004) para estudar o efeito que diferentes cenários econômicos provocam na trajetória da dívida pública. Embora não pretenda chegar a carteiras ótimas, ele analisa efeitos a partir da simulação na trajetória da razão dívida/PIB para diferentes carteiras de dívida, classificando-as conforme risco e retorno. Primeiramente, faz esse exercício para um cenário base e posteriormente para cenários com políticas monetárias e fiscais alternativas.

Sua metodologia é bem parecida com aquela verificada em Lopes e Domingos (2004). O

\footnotetext{
${ }^{49}$ A especificação da equação para o risco-país teve várias variáveis relevantes omitidas, causando sério viés no parâmetro da dívida. Para ver quais seriam essas variáveis, consultar Muinhos, Alves e Riella (2002), Canuto e Santos (2003), Megale (2003) e Yuki (2004), por exemplo. Mais à frente, elas serão incluídas na especificação da equação do risco-país no modelo utilizado para o estudo empírico desta dissertação.
} 
modelo é similar, porém ele apresenta um componente de expectativas racionais na curva de Phillips, tornando-a forward-looking, e não trabalha com uma equação para o Embi. Assim, seu modelo foi estabelecido da seguinte maneira:

$$
\begin{aligned}
& y_{t+1}=\alpha_{0}+\alpha_{1} y_{t}+\alpha_{2} r_{t}+\alpha_{3} e_{t}+\varepsilon_{t+1}^{y} \\
& \pi_{t+1}=\beta_{0}+\beta_{1} \pi^{\varepsilon}+\beta_{2} y_{t}+\beta_{3} y_{t-1}+\beta_{4}\left(e_{t}-e_{t-1}\right)+\varepsilon_{t+1}^{\pi} \\
& e_{t+1}=\delta_{0}+\delta_{1} e_{t}+\delta_{2} r_{t}+\delta_{3} \varphi+\varepsilon_{t+1}^{e} \\
& r_{t+1}=\vartheta r_{t}+\gamma_{1} \pi_{t}+\gamma_{2} y_{t}
\end{aligned}
$$

onde $y$ é o hiato, $r$ a taxa nominal de juros, $e$ a taxa de câmbio, $\pi$ a inflação, $\pi^{\varepsilon}$ a expectativa de inflação e $\varphi$ o prêmio de risco.

A evolução da Dívida/PIB é definida como em Lopes e Domingos (2004), assim como o custo de carregamento da dívida. A estimação é feita com uma amostra trimestral, de 1994 a 2005, usando os métodos de MQO e MQG (Mínimos Quadrados Generalizados), sendo a equação da regra de juros calibrada ao invés de estimada.

Em seu cenário base, o autor simula a economia utilizando um superávit primário de 4,25\% do PIB $^{50}$. Para computar o custo de carregamento da dívida, ele incorpora um prêmio de risco para os ativos prefixados ${ }^{51}$. A expectativa de inflação não é modelada e, desta maneira, Borges (2006) fixa o valor em 4,32\% pra toda a simulação.

Quando a regra monetária considerada é aquela em que os pesos são iguais para a inflação e o produto, o estudo encontra, como resultado, que as carteiras de dívida indexadas totalmente ao câmbio têm um risco significativamente superior entre as carteiras de canto (composta somente por um tipo de indexador). A carteira de dívida prefixada tem o menor risco, porém o maior custo esperado. Já a carteira de dívida indexada à taxa Selic tem o segundo menor risco e o menor custo esperado. Por último, a carteira com dívida indexada à inflação tem o terceiro maior risco (ligeiramente superior à carteira indexada aos juros) e terceiro maior custo esperado.

\footnotetext{
${ }^{50}$ As simulações são para 40 períodos à frente.

${ }^{51}$ Apesar de não explicitar o valor utilizado, Borges (2006) cita estudos em que o prêmio de risco foi estimado em torno de 3,5\% ao ano. Assim, provavelmente esse foi o valor aproximado utilizado nas simulações do autor.
} 
Por outro lado, quando a regra monetária coloca um peso bem maior na inflação (90\%), os resultados são alterados. Em termos de risco, o menor valor continua sendo o da carteira de dívida prefixada, seguido pela carteira indexada aos juros e aos preços - essas duas com riscos bem similares. O risco da carteira cambial continua sendo significamente superior. Já em termos de custo, a carteira indexada aos juros fica a mais cara de todas, seguida pela prefixada. O menor custo fica com a carteira indexada a preços, seguida pela carteira cambial.

As mudanças em termos de resultados para diferentes regras monetárias são explicadas por Borges (2006) como uma conseqüência do ambiente econômico proporcionado por elas. No caso em que a autoridade monetária se preocupa muito mais com a inflação, os juros tendem a ser mais altos, ocasionando uma redução da inflação e uma apreciação cambial. Por isso, as carteiras com títulos indexados a essas variáveis têm um desempenho significativamente melhor do que no caso contrário ${ }^{52}$.

Desta maneira, o trabalho de Borges (2006), embora não pretenda construir um benchmark para a gestão da dívida, acaba fornecendo maiores insights sobre o desempenho de diferentes carteiras de dívida em distintos cenários macroeconômicos. Também já apresenta um aperfeiçoamento em relação ao trabalho de Lopes e Domingos (2004), principalmente ao incorporar um prêmio para o ativo prefixado, a dar maior consistência ao modelo macroeconômico (com resultados mais realistas) ${ }^{53}$ e a estimar a curva de Phillips com a característica forward-looking. Por outro lado, o autor trabalhou com poucas carteiras de dívida, privilegiando as carteiras de canto, pode ter estabelecido um prêmio de risco elevado para os padrões atuais, deixou de permitir um feedback da dívida no modelo e, durante a simulação, não trabalhou de fato com uma abordagem forward-looking ${ }^{54}$.

Cabral, Lopes et al. (2008) também derivam uma fronteira eficiente para a gestão da dívida pública brasileira, para servir como um benchmark para os gestores da dívida. No entanto, ao invés de simularem a economia através de um modelo macro-estrutural, os autores utilizam métodos de finanças estocásticas. Partindo do pressuposto de que a economia se encontra em

\footnotetext{
${ }^{52}$ Ainda que o risco da carteira com títulos indexados ao câmbio continue bastante elevado.

${ }^{53}$ Uma das alterações no modelo foi uma melhor especificação da equação do câmbio, por exemplo.

${ }^{54}$ Embora tenha-se estimado a curva de Phillips forward-looking, a simulação do modelo não endogenizou a expectativa de inflação. Desta maneira, pode-se dizer que a simulação não foi de fato forward-looking, pois as expectativas de inflação não foram formadas endogenamente.
} 
estado estacionário ${ }^{55}$, eles modelam as variáveis juros, câmbio, inflação e produto através de modelos de finanças (CIR, CKLS e GBM $)^{56}$. Além disso, impõem ao modelo uma consistência macroeconômica, a partir da estimação de uma matriz de covariância entre as variáveis macroeconômicas.

Os resultados não foram apresentados, mas, segundo os autores, eles indicaram que haveria espaço para ganho de eficiência, isto é, uma escolha entre diminuir o risco ou diminuir o custo esperado da dívida ${ }^{57}$. Essa melhora dentro da fronteira eficiente seria possível com o aumento da parcela de títulos indexados à inflação, bem como dos títulos prefixados. Por outro lado, a parcela de títulos indexados à taxa Selic deveria ser diminuída. Essa redução, entretanto, deveria ser gradual, pois, apesar de terem um custo mais volátil, esta parcela de dívida ajudaria na redução de custos enquanto a economia estivesse caminhando para um cenário de taxas de juros mais baixas.

Alves (2009) estuda o impacto de choques nas principais variáveis que determinam o custo da dívida pública, determinando composições eficientes para a dívida pública. Seu estudo é realizado a partir da simulação da economia por um modelo macro-estrutural, de maneira a possibilitar a análise de risco e retorno para diversas composições de dívida, da mesma maneira que em trabalhos anteriores. Seu modelo é descrito pelas seguintes equações:

$$
\begin{aligned}
& y_{t+1}=\alpha_{0}+\alpha_{1} y_{t}+\alpha_{2}\left(i_{t}(0)-\pi_{t}\right)+\varepsilon_{t+1}^{y} \\
& \pi_{t+1}=\bar{\pi}\left(1-\delta_{1}\right)+\delta_{1} \pi_{t}+\delta_{2} y_{t}+\delta_{3}\left(e_{t}-e_{t-1}\right)+\varepsilon_{t+1}^{\pi} \\
& e_{t+1}=\theta_{0}+\theta_{1} e_{t}+\theta_{2}\left(i_{t}(0)-\pi_{t}\right)+\varepsilon_{t+1}^{e} \\
& i_{t+1}=\bar{i}(1-\rho)+\rho i_{t}(0)+\kappa\left(\pi_{t+1}-\bar{\pi}\right)+\psi y_{t+1}
\end{aligned}
$$

onde $y$ é o hiato, $i(0)$ é a taxa nominal de juros de curto prazo, $\pi$ denota a inflação, $e$ é a taxa

\footnotetext{
${ }^{55}$ Como partem de um cenários de estado estacionário, os autores ressaltam: "this scenario is to be attained possibly in the next few years, in such a manner that our analysis should be interpreted to proceed from that point of time onwards" (CABRAL, LOPES ET AL., 2008)

${ }_{56}$ CIR (Cox, Ingersoll e Ross); CKLS (Chan, Karolyi, Longstaff e Sanders); GBM (Geometric Brownian Motion). Não é objetivo desta dissertação entrar a fundo nesses modelos. Para maiores detalhes, ver Hull (1998).

${ }^{57}$ Cabral, Lopes et al. (2008) afirmam que, de acordo com as melhores práticas internacionais, o papel dos gestores da dívida acaba na construção da fronteira de Markowitz, sendo que a escolha do nível de risco fica a cargo do responsável pela política fiscal (geralmente o Ministro das Finanças).
} 
de câmbio, $\bar{\pi}$ é a meta de inflação e $\bar{l}$ a taxa de juros de longo prazo.

A evolução da Dívida/PIB é determinada em função da evolução de quatro categorias dos ativos e passivos que compõem a DLSP $(d)$ - a DPF $(x)$, a base monetária $(m)$, as reservas internacionais $(f)$ e outros passivos líquidos do setor público $(l)$ - além do crescimento do produto $(\gamma)$ e do superávit primário $(s)$, conforme a seguinte equação:

$d_{t}=x_{t-1} \frac{\left(1+c_{t}\right)}{\left(1+\gamma_{t}\right)}-s_{t}+\frac{m}{\left(1+\gamma_{t}\right)}-f_{t-1} \frac{\left(1+c_{t}^{\text {reserves }}\right)}{\left(1+\gamma_{t}\right)}+l_{t-1} \frac{\left(1+c_{t}^{l}\right)}{\left(1+\gamma_{t}\right)}$

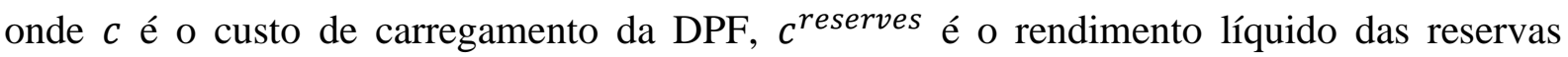
(incluindo a depreciação/apreciação cambial) e $c^{l}$ é o custo de carregamento dos demais passivos líquidos do setor público. O superávit primário é determinado em função do hiato do produto, seguindo a equação $s_{t+1}=v_{0}+v_{1} y_{t}$.

Para o exercício empírico, Alves (2009) utiliza um misto de calibração e estimação. A calibração é justificada pela pequena amostra disponível para a economia brasileira dentro do mesmo regime macroeconômico ${ }^{58}$. Além disso, o autor destaca que o modelo tem o propósito de avaliar a dívida no longo prazo e, desta forma, seria válido trabalhar com valores de longo prazo $^{59}$. A regra de juros não é estimada e, da mesma forma que trabalhos anteriores, o autor trabalha com duas versões desta regra: uma com peso maior na inflação e a outra com pesos iguais para inflação e produto.

No seu modelo, o autor introduz títulos com diferentes prazos de maturação. Desta maneira, a composição eficiente perseguida por ele se refere também a diferentes prazos. Além das equações que determinam a evolução da economia, o modelo de Alves (2009) apresenta, portanto, curvas de rendimento para definir o custo de cada título. As curvas seguem os trabalhos de Nelson e Siegel (1983), Dielbold e Li (2006) e Pick e Anthony (2006).

A especificação completa gera trajetórias para as variáveis macroeconômicas, utilizadas para determinar a evolução da relação Dívida/PIB. Como existe a modelagem da curva de juros, a

\footnotetext{
${ }^{58}$ Os dados utilizados foram trimestrais, relativos ao período entre 2000 e 2008.

${ }^{59}$ Seguindo esse raciocínio, o autor estabelece a taxa de juros de longo prazo em $8 \%$ ao ano, a meta de inflação em $3,5 \%$ ao ano e o crescimento do produto potencial em $4,5 \%$ ao ano.
} 
análise é estendida para títulos de longo prazo, tornando a simulação ${ }^{60}$ mais completa.

O autor calcula a fronteira eficiente para a composição da dívida tanto em relação aos valores da Dívida/PIB (DLSP/PIB) quanto para os valores da DPF/PIB. Para o primeiro caso, as carteiras com o menor custo esperado são aquelas com maior risco e são compostas por títulos indexados ao câmbio e à taxa de juros. Carteiras com custo esperado e risco intermediários são aquelas que também incluem títulos prefixados. A inclusão de títulos indexados aos preços torna a carteira menos arriscada, embora mais custosa ex-ante. Porém, essa inclusão depende da regra de política monetária considerada: na regra de pesos iguais para inflação e produto, as carteiras eficientes apresentam grande parte destes títulos. Na regra alternativa, onde o peso é maior na inflação, as carteiras eficientes não contam com títulos indexados aos preços.

Para o segundo caso, as carteiras com o menor custo esperado apresentam maior risco e são compostas por altas parcelas de títulos indexados ao câmbio e à taxa de juros. A diferença aqui, em comparação com o caso em que se observa a DLSP/PIB, é que os títulos indexados ao câmbio têm a participação bastante reduzida nas carteiras eficientes de risco menor, sendo substituídas por títulos prefixados nas carteiras eficientes de risco intermediário e por títulos indexados aos preços, nas carteiras eficientes de menor risco. Essa diferença ocorre basicamente porque no primeiro caso, que trata da DLSP, uma parcela dos títulos indexados ao câmbio na carteira tem um hedge nas reservas internacionais. Assim, naquele caso, o risco associado àquele instrumento é nulo até o volume em que está casado com o ativo indexado ao câmbio.

A principal conclusão do trabalho de Alves (2009) é que, independentemente dos prazos, a presença de títulos prefixados e indexados aos preços é fundamental para a redução o risco da DPF. Uma carteira composta por esses títulos fornece proteção contra choques de oferta e de demanda na economia, além de ter um bom desempenho com diferentes regimes de política monetária $^{61}$.

\footnotetext{
${ }^{60}$ A simulação é feita para 10 anos, assumindo uma situação de estado estacionário.

${ }^{61} \mathrm{O}$ autor ressalta que outros fatores influenciam na gestão da dívida, aparecendo como restrições para o alcance da fronteira eficiente, como já vimos anteriormente. Dentre esses, cita o impacto das ações do governo no mercado de títulos e a dependência em um mercado de capitais desenvolvido e com ampla base de investidores. Por isso, mudanças na composição da dívida normalmente são graduais e dependentes das condições de mercado.
} 


\subsection{Conclusões}

A evolução da literatura sobre a composição ideal da dívida pública nos mostra que houve, nos últimos anos, uma tendência para a construção de benchmarks para orientar a gestão da dívida. Os trabalhos de Lopes e Domingos (2004), Borges (2006), Cabral, Lopes et al. (2008) e Alves (2009) consistiram em simulações estocásticas da economia, estabelecendo cenários macroeconômicos que foram utilizados para analisar o comportamento de diversas carteiras de dívida pública, a partir de uma análise de risco e retorno. Essa também vem sendo a metodologia utilizada por gestores de dívida de diversos países, como Portugal, Suécia e Dinamarca.

Os resultados obtidos em cada um desses trabalhos demonstraram uma convergência em relação às recomendações em termos da composição da dívida pública. Todos eles ressaltam a importância dos títulos prefixados e indexados aos preços na formação de carteiras eficientes para a dívida pública. Todavia, acredita-se que ainda há espaço para continuar estudando a composição ótima da dívida brasileira. Nesse ponto, algumas questões podem ser destacadas: (i) ainda não se trabalhou o tema com a utilização de um modelo macro-estrutural com expectativas racionais (forward-looking) de maneira completa ${ }^{62}$, (ii) o prêmio de risco dos títulos prefixados ainda é um tópico pouco explorado ${ }^{63}$, (iii) a regra de política monetária ainda não foi estimada e também ainda não apresentou um termo de erro ${ }^{64} \mathrm{e}$ (iv) a diferença em termos de composição eficiente da carteira da dívida relativas a regras de política monetária distintas ainda não está clara ${ }^{65}$. Além desses, destaca-se a importância de ser estabelecido um elo entre o modelo macroeconômico e a evolução da razão Dívida/PIB, dada pelo seu custo de carregamento e outros determinantes. Esse feedback só foi verificado no

\footnotetext{
${ }^{62} \mathrm{O}$ único desses trabalhos a utilizar um modelo de expectativas racionais foi o de Borges (2006). Porém, durante a estimação, ele não levou em conta a possível endogeneidade nas equações forward-looking e, durante a simulação, ele não endogenizou a formação das expectativas de inflação. Esse fato acaba distorcendo a igualdade ex-ante das rentabilidades de cada ativo, porque o cálculo do prêmio do título indexado à inflação leva em conta a expectativa de inflação para o período. Assim, se essa não corresponde aos valores fornecidos endogenamente pelo modelo, a rentabilidade ex-ante do título indexado aos preços fica diferente daquele indexados aos juros, por exemplo, prejudicando a demanda daquele que tiver a menor rentabilidade ex-ante.

${ }^{63}$ Lopes e Domingos (2004) não estabelecem um prêmio de risco ao ativo prefixado, enquanto Borges (2006) determina um valor único. O mesmo ocorre em Alves (2009). A idéia nesta dissertação é trabalhar com prêmios de risco diferenciados, de modo a tratar a questão da composição ótima em diferentes cenários conjunturais.

${ }^{64} \mathrm{O}$ termo de erro (choque) na equação dos juros é importante principalmente quando os juros em $t$ estão em função de variáveis defasadas. Quando não há choque, nesse caso, significa que a previsão dos agentes a respeito dos juros para o período seguinte é perfeita, fato pouco realista e prejudicial à estrutura de rentabilidade dos ativos.

${ }^{65}$ Por exemplo, os trabalhos de Lopes e Domingos (2004) e Alves (2009) chegam a resultados distintos. Para a regra monetária com peso maior na inflação, o primeiro trabalho indica maior importância de títulos indexados à inflação, resultado que não está presente no segundo trabalho.
} 
trabalho de Lopes e Domingos (2004) e constitui uma característica importante para a realização de um estudo como esse, já que a dívida tem impacto na trajetória das variáveis macroeconômicas.

Desta maneira, o objetivo desta dissertação é seguir na busca de um benchmark para a administração da dívida pública brasileira, preocupando-se com a minimização da volatilidade orçamentária do governo. Para seguir com este objetivo, será seguida a literatura apresentada, de maneira que sejam incluídos alguns aperfeiçoamentos, como os descritos no parágrafo anterior. Assim, no próximo capítulo, são apresentados os detalhes do exercício empírico e os resultados encontrados. 


\section{UM ESTUDO EMPÍRICO}

Como foi visto nos capítulos anteriores, a experiência internacional indica que, nos últimos anos, gestores de diversos países estão utilizando um benchmark como uma ferramenta de gestão da dívida pública. Tal metodologia seria consistente com as recomendações de organismos multilaterais ${ }^{66}$. Segundo Alves (2009), por exemplo, órgãos como o Banco Mundial e o FMI, recomendam que os gestores de dívida soberana adotem modelos de benchmark como ferramenta de gerenciamento de risco e planejamento estratégico.

Desta maneira, pesquisas em torno de uma metodologia para determinar um benchmark vêm ocupando um lugar de destaque na agenda de gestores de dívida e outros especialistas em vários países. Vimos ainda que, na maior parte das vezes, esse benchmark é construído através de simulações com algum tipo de modelo, sendo que os modelos macro-estruturais ${ }^{67}$ estão tendo destaque na literatura.

Desta maneira, esta dissertação busca estudar estratégias eficientes para a gestão da dívida pública brasileira, subsidiando a construção de um benchmark para a gestão da dívida pública brasileira. A primeira seção deste capítulo descreve o modelo utilizado, incluindo as fundamentações teóricas. Apesar de ser da classe dos modelos que tem origem microfundamentada, não será objetivo do presente trabalho apresentar a sua microfundamentação ${ }^{68}$. Em seguida, explica-se o exercício empírico a ser realizado e apresentam-se os dados e as estimações. Por último, seguem os exercícios de simulação, bem como a análise dos resultados encontrados.

\subsection{Modelo Utilizado}

\subsubsection{Fundamentações Teóricas}

Nos últimos anos, os modelos de inspiração novo-keynesiana ganharam força e começaram a

\footnotetext{
${ }^{66}$ FMI e Banco Mundial (2001) - Guidelines for public debt management.

${ }^{67}$ Desenvolvimentos recentes dos modelos macroeconômicos estruturais de pequena escala têm sua origem nos trabalhos de Taylor (1994), Ball (1999) e Svensson (2000), dentre outros, que buscaram representar o funcionamento da economia e os efeitos de política monetária através de uma ferramenta simples e poderosa.

${ }^{68} \mathrm{O}$ modelo é resolvido pela maximização dos problemas das famílias e das firmas. As relações daí derivadas são equações não lineares, não apresentando, portanto, soluções fechadas. Por isso, para chegar as equações de equilíbrio lineares, realiza-se a log-linearização em torno do estado estacionário, onde as variáveis são constantes. Para detalhes, consultar Woodford (2003).
} 
substituir o modelo IS-LM-OA na análise de políticas macroeconômicas (CLARIDA et al., 1999; ROMER, 2000). Basicamente, eles se modificam em relação à abordagem anterior através da substituição da curva LM por uma regra de política monetária a ser seguida pelo BC. Além disso, eles são derivados a partir de microfundamentos, fazendo com que os parâmetros tenham interpretações estruturais e apresentando uma solução à crítica de Lucas.

Para explicar o surgimento desses modelos, da forma atual, convém voltar um passo atrás, quando a política monetária era considerada neutra no curto e no longo prazo, os modelos dentro da tradição de ciclos reais estavam mais preocupados com os fatores não-monetários que afetavam o ciclo econômico e a recomendação usual de política monetária era uma regra passiva, como as metas para os agregados monetários.

A partir dos anos 80, acontecimentos em diferentes frentes foram mudando esse cenário. Em primeiro lugar, surgiram várias evidências empíricas de que a política monetária influenciava significativamente o lado real da economia no curto prazo (CHRISTIANO et al., 1999; CHRISTIANO et al., 2005; SIMS, 1992). Concomitantemente a isso, a regra de metas para agregados monetários passou a ser inviabilizada pelo surgimento de inovações financeiras que tornavam as velocidades de circulação dos vários agregados monetários mais voláteis e incertas.

Assim, no plano prático de política monetária, a tendência passou a ser a adoção de uma regra de Taylor, que na maioria das vezes está ligada ao regime das metas de inflação. No plano teórico, por sua vez, originou-se uma preocupação em adaptar os modelos anteriores às evidências empíricas encontradas, através da inclusão de diversas fricções no modelo de ciclos reais (rigidez de preços, rigidez de salários, custos de ajustamento, etc.).

Portanto, hoje em dia, têm-se uma literatura intensa em política monetária que utiliza os modelos novo-keynesianos para avaliar o desempenho de regras monetárias diversas sob diferentes ambientes institucionais. $\mathrm{O}$ ressurgimento desse interesse em política monetária, conforme já visto, estaria sendo motivado pela crença em seus efeitos reais no curto prazo e pelo aperfeiçoamento dos modelos de equilíbrio geral dinâmico, que incorporaram as fricções necessárias para se adequar aos dados empíricos. (CLARIDA et al., 1999)

Desta maneira, em sua versão mais simples, o modelo consiste em três equações (blocos). A 
primeira é a curva IS, que descreve o lado da demanda agregada da economia. A segunda é a curva de Phillips, que descreve a oferta agregada. Por último, têm-se a regra de política monetária, que é a regra seguida pelo Banco Central para determinar a taxa de juros nominal da economia e que segue uma especificação à la Taylor.

A importância dos modelos macroeconômicos de pequena escala é destacada por vários autores. Enquanto Bonomo e Brito (2002) os consideram uma ferramenta poderosa para simulação e análise de políticas, com uma utilização cada vez maior, Muinhos, Alves e Riella (2002) acreditam que eles são fundamentais no apoio às decisões de política monetária, apresentando grande capacidade de previsão para as principais variáveis da economia no curto prazo.

\subsubsection{Modelo Escolhido}

Após o estudo de diferentes modelos, apresentamos abaixo um modelo semelhante ao encontrado em Bogdanski, Tombini e Werlang (2000), que se tornou uma referência importante em modelos macro-estruturais de pequena escala para o Brasil, logo no início do novo regime de política monetária. A justificativa para a utilização deste modelo é a sua constante presença em trabalhos similares, como vimos no capítulo anterior. Além disso, é uma metodologia mais rigorosa ${ }^{69}$ para gerar o cenário macroeconômico futuro, importante para a simulação do comportamento da dívida. Em relação ao trabalho de Bogdanski, Tombini e Werlang (2000), o modelo aqui especificado adiciona uma equação para o risco país, conforme descrito a seguir. Assim, o modelo utilizado será composto por cinco equações $^{70}$ :

$$
\begin{aligned}
& y_{t}=\alpha_{0}+\alpha_{1} y_{t-1}+\alpha_{2}\left(i_{t-1}+\pi_{t-1}\right)+\alpha_{3} e_{t-1}+\varepsilon_{t}^{y} \\
& \pi_{t}=\beta_{0}+\beta_{1} E_{t} \pi_{t+1}+\beta_{2} \pi_{t-1}+\beta_{3} y_{t-1}+\beta_{4} \Delta e_{t-1}+\varepsilon_{t}^{\pi} \\
& e_{t}=\delta_{0}+\delta_{1} e_{t-1}+\delta_{2}\left(i_{t-1}+\pi_{t-1}\right)+\delta_{3} E m b i_{t-1}+\varepsilon_{t}^{e}
\end{aligned}
$$

\footnotetext{
${ }^{69}$ Azeredo (2002) também estuda a composição da dívida pública utilizando uma simulação macroeconômica para verificar o comportamento de diversas carteiras de dívida. No entanto, e até pela dificuldade amostral no período em que o estudo foi realizado, ele gera as variáveis macroeconômicas com base nas médias e covariâncias históricas destas variáveis, assumindo ausência de autocorrelação. Assim, hoje em dia, com o aumento da amostra do período das metas de inflação, desde 1999, podemos utilizar técnicas mais rigorosas para gerar essas variáveis, como um modelo macro-estrutural.

${ }^{70}$ Obviamente, a inclusão ou não de alguma outra variável no modelo depende dos resultados econométricos obtidos com ela.
} 
$E m b i_{t}=\theta_{0}+\theta_{1} E_{m b i}+\theta_{2-1} D V_{t-1}+\theta_{3} \operatorname{Res}_{t-1}+\theta_{4}$ Trans $_{t-1}+\theta_{5} L_{t}+\varepsilon_{t}^{E}$

$i_{t}=\rho i_{t-1}+\psi E_{t} \pi_{t+1}+\phi y_{t-1}+\varepsilon_{t}^{i}$

onde $y$ é o hiato do produto, $i$ corresponde a taxa de juros nominal, $\pi$ é a inflação realizada, $e$ é a taxa de câmbio real, Embi é o risco-país, DIV é a razão Dívida/PIB, Res denota as reservas internacionais, Trans representa o saldo em transações correntes, $L$ é o grau de liquidez internacional e $\varepsilon_{t}^{y}, \varepsilon_{t}^{\pi}, \varepsilon_{t}^{e}, \varepsilon_{t}^{E} e \varepsilon_{t}^{i}$ são os termos de erro, que seguem uma distribuição normal.

A equação (4.1) é uma curva IS para uma economia aberta, onde o hiato do produto hoje depende do hiato do produto do período anterior, da taxa real de juros e do câmbio real do período anterior $^{7172}$. A equação (4.2) é uma curva de Phillips forward-looking, que relaciona a inflação atual com a expectativa de inflação para o período seguinte, com a inflação e a taxa de câmbio real do período anterior e mais a variação cambial do período anterior. A equação (4.3) diz que o câmbio é explicado pela taxa de câmbio e taxa de juros real do período anterior. Ela é uma versão modificada da paridade descoberta da taxa de juros apresentada em Bogdanski, Tombini e Werlang (2000). Em seguida, a equação (4.4) relaciona o risco-país com seu valor no período anterior, com o valor da dívida, das reservas e do saldo em transações correntes do período anterior e com o valor da liquidez internacional no mesmo período $^{73}$. Por último, a equação (4.5) se refere à regra monetária adotada pelo Banco Central, que estabelece o nível da taxa de juros nominal da economia em $t$ em função da taxa de juros em $t-1$, da inflação esperada para o período seguinte e do hiato do produto em $t-1$.

O modelo acima será também estimado em uma versão backward-looking, de maneira que o coeficiente $\beta_{1}$ seja zero, na segunda equação, e o termo multiplicando $\psi$ na quarta equação seja substituído por inflação em $t-1$. O objetivo deste exercício é conseguir maior robustez nos resultados finais, isto é, verificar se a realização de alguns ajustes no modelo permite que

\footnotetext{
${ }^{71}$ Embora se tenha preferido uma especificação mais simples, alguns autores incluem na curva IS uma série de outras variáveis, como fiscais (resultado primário, por exemplo), externas (como termos de troca ou demanda externa) e até mesmo o risco país. Ver, por exemplo, Santos e Holland (2008) e Carvalho (2008).

${ }^{72}$ Poder-se-ia ainda pensar em incluir a expectativa do hiato como variável explicativa, tornando a equação forward-looking. Tal alteração, no entanto, é dificultada por questões relativas à obtenção de dados. De qualquer forma, Bonomo e Brito (2002) encontram evidências de que, para o Brasil, enquanto a curva de Phillips é predominantemente forward-looking, a IS é predominantemente backward-looking.

73 Com exceção da variável liquidez internacional, as outras são as que estão presentes na equação de risco-país desenvolvida por Muinhos, Alves e Riella (2002).
} 
se mantenham os principais resultados e conclusões obtidos com a simulação.

Além das equações acima, trabalharemos com duas equações determinísticas, sendo uma que indica o custo de carregamento da dívida, com base na parcela alocada a cada indexador e sua respectiva rentabilidade, e a outra que indica a evolução da relação Dívida/PIB, com base no seu custo de carregamento, no crescimento da economia e no superávit primário obtido pelo governo. Assim, chamaremos de (4.6) a seguinte equação, que descreve o custo de carregamento da dívida:

$C C_{t}=\left(\phi_{t}^{\pi} * R_{t}^{\pi}\right)+\left(\phi_{t}^{e} * R_{t}^{e}\right)+\left(\phi_{t}^{i} * R_{t}^{i}\right)+\left(\phi_{t}^{p r e ́} * R_{t}^{p r e ́}\right)$

Onde $\phi^{\pi}, \phi^{e}, \phi^{i} e \phi^{p r e ́}$ são as parcelas alocadas respectivamente aos títulos indexados aos preços, câmbio, juros nominais e os prefixados e $R^{\pi}, R^{e}, R^{i}$ e $R^{\text {pré }}$ denotam as rentabilidades dos respectivos títulos ${ }^{74}$.

Por fim, a equação (4.7) abaixo determina a evolução da relação dívida/PIB da economia:

$D I V_{t}=\left(\frac{C C_{t}}{1+g_{t}}\right) * D I V_{t-1}-S U P_{t}$

sendo que $C C$ já foi definido em (4.5), g é o crescimento econômico e $S U P$ é o superávit primário, medido em proporção do PIB. Obviamente, deve-se ter em mente, em compasso com o capítulo 1, os diferentes conceitos de dívida. O indicador a ser usado aqui é a DLSP e, em sua evolução, só está sendo considerado o custo de carregamento, o crescimento e o superávit primário. Assim, estão sendo desconsiderados, por exemplo, a senhoriagem, as receitas financeiras dos ativos do setor público $^{75}$, as receitas de privatização e o reconhecimento de dívidas antigas. Acredita-se, no entanto, que tal simplificação não trará prejuízos aos resultados e possibilitará um maior foco nas questões estudadas.

\footnotetext{
${ }^{74}$ A definição das rentabilidades está definida no apêndice, para não prejudicar a sequência do texto.

75 Nesse ponto, sobressaem-se as receitas relativas às reservas internacionais. No entanto, como as reservas variam de acordo com a conjuntura e as orientações macroeconômicas em vigor, pretende-se analisá-las apenas qualitativamente, tendo em mente que elas podem fornecer um hedge para uma dívida indexada ao câmbio.
} 


\subsection{Exercício Empírico}

A estratégia para a construção de um benchmark para a dívida pública brasileira, objetivo desta dissertação, seguirá em linhas gerais aquelas utilizadas em Lopes e Domingos (2004), Borges (2006) e Alves (2009). Após a escolha e a estimação do modelo, realizar-se-á uma simulação estocástica da economia, gerando trajetórias futuras para as variáveis macroeconômicas. Esta simulação será feita 5.000 vezes, para 20 períodos (trimestres) à frente, gerando 5.000 cenários distintos. O passo seguinte será verificar como carteiras com diferentes composições de dívida se comportarão em cada uma das trajetórias geradas. Como teremos 5.000 trajetórias da dívida pública para cada carteira, poderemos calcular a média e o desvio padrão do valor da dívida pública ao final do período simulado, medidas que corresponderão ao retorno e ao risco da carteira estudada.

Serão quatro modelos diferentes, sendo que a diferença entre eles estará no tipo das expectativas utilizadas e no tipo da regra monetária adotada. A idéia, ao utilizar maior número de modelos, é verificar como os resultados se comportam quando se mudam algumas premissas importantes.

Na próxima seção, são apresentadas as séries utilizadas, bem como o seu período amostral, e os resultados das estimações. Em seguida, são apresentados o exercício da simulação, suas principais premissas, os quatro modelos utilizados e as carteiras de dívida consideradas. Por último, seguem os resultados de cada modelo e os comentários finais em relação ao exercício.

\subsection{Dados}

A amostra compreende dados trimestrais do primeiro trimestre de 1999 ao terceiro trimestre de 2010. As variáveis são:

(i) Hiato do produto (Y): Foi obtida através da aplicação do filtro de Hodrick-Prescott (HP) à série do PIB a preços de mercado dessazonalizado trimestral, obtida no Ipeadata. O filtro HP foi utilizado com lambda igual a 1.600 (recomendado para séries trimestrais) e com dados a partir de 1996, para pegar uma faixa mais ampla da série (o hiato também foi calculado com dados a partir de 1997 e 1998 e as três formas deram resultados bastante similares). 
(ii) Taxa de juros nominal (I): Obtida através da série Taxa de juros Selic Overnight (a.m.), mensal, disponível no Ipeadata. Anualizou-se a taxa e trabalhou com a média dos três meses compreendidos no trimestre. A taxa real foi obtida subtraindo da taxa nominal a inflação observada nos últimos 12 meses.

(iii) Inflação (INF): inflação medida pelo IPCA, acumulada nos 12 meses anteriores, obtidas no Ipeadata. Como a série é mensal, calculou-se a média dos seus três meses.

(iv) Expectativa (EXPECT): Expectativa média de inflação para os próximos 12 meses, calculada pelo Banco Central e obtidas através do Ipeadata. Novamente, como a série é mensal, obteve-se o valor trimestral pela média dos seus três meses. Ressalta-se que esta variável só está disponível a partir do terceiro trimestre de 2001, prejudicando a estimação das curvas de Phillips e Taylor forward-looking.

(v) Câmbio (E): É a taxa de câmbio efetiva, com base numa cesta de moedas baseadas nas exportações brasileiras, calculadas pelo IPEA e disponíveis no Ipeadata. Novamente, como a série é mensal, calculou-se a média dos seus três meses.

(vi) Embi (EMBI): o risco país é representado pelo EMBI Brasil, índice calculado pelo J.P. Morgan e obtido no site do CORECON-SP. Com a série é diária, o valor trimestral foi calculado como uma média do último dia de cada mês.

(vii) Dívida (DIV): Dívida Líquida do Setor Público, sobre o PIB. A série está disponível no Ipeadata e seu valor por trimestre foi obtido pela média de seus valores mensais.

(viii) Reservas (RES): Primeiramente, transformou-se a série mensal de Reservas Internacionais, em US\$, disponível no Ipeadata, para uma série trimestral. Em seguida, mudou-se a moeda da série para Reais, utilizando a média da taxa de câmbio nominal do dólar mensal para o trimestre (série também disponível no Ipeadata). Por último, colocou-se o valor obtido sobre o PIB nominal trimestral, obtido junto ao Ipeadata.

(ix) Transações Correntes (TRANS): Utilizou-se a série mensal de transações correntes dos 12 meses anteriores sobre o PIB, disponível no Ipeadata e transformada para valores trimestrais pela média mensal. 
(x) Liquidez Internacional (VIX): Utilizou-se, como medida de liquidez internacional, o índice VIX (Volatility Index), calculado pela Chicago Board Options Exchange com base no S\&P 500. A série é mensal e foi transformada em trimestral pela média dos meses do trimestre. Ressalta-se que, quanto maior o valor deste índice, maior o grau de aversão ao risco da economia e, portanto, menor a liquidez internacional. Assim, valores maiores indicam menor liquidez.

\subsection{Estimações}

Para realizar as estimações, primeiramente foram feitos os testes de raiz unitária para a todas as séries. Embora pelo ADF não tenha sido possível rejeitar a hipótese nula de presença de raiz unitária para algumas delas, pelo KPSS foi possível considerar todas elas como estacionárias $^{76}$. Desta maneira, o modelo pode ser estimado sem a necessidade de diferenciação das séries ${ }^{77}$.

A Tabela 6 apresenta os parâmetros estimados para o modelo backward-looking, pelo método dos Mínimos Quadrados Ordinários (MQO). De maneira geral, os resultados foram em linha com os trabalhos empíricos anteriores, bem como os valores esperados para cada coeficiente. Com o sinal contrário ao esperado, somente o sinal do câmbio na equação IS. Esse valor, apesar de contra-intuitivo, não é incomum em trabalhos aplicados ao Brasil ${ }^{78}$. Além disso, o sinal do hiato do produto na curva de Phillips, apesar de apresentar o sinal esperado, não foi significativo. Este resultado também não é nenhuma novidade, sendo frequentemente encontrado na literatura ${ }^{79}$.

A Tabela 7 apresenta os parâmetros estimados para o modelo forward-looking, também por MQO. Obviamente, só estão presentes os parâmetros estimados para as duas equações que foram estimadas nesse formato, a de Phillips e a regra de Taylor. Ressalta-se que o coeficiente do hiato na primeira continuou não significativo, embora tenha o sinal esperado.

\footnotetext{
${ }^{76}$ Os detalhes e resultados dos testes estão no Anexo II.

${ }^{77}$ De qualquer maneira, como o interesse aqui está centrado na previsão das variáveis econômicas, ao invés da relação de causalidade entre elas, a exigência de estacionariedade se torna menos estrita.

${ }^{78}$ Santos e Holland (2008), por exemplo.

${ }^{79}$ Schwartzman (2006), por exemplo, se refere a ele como "o problema normalmente encontrado de baixa significância do parâmetro para o hiato do produto".
} 
Tabela 6 - Resultados das estimativas Modelo Backward-Looking ${ }^{80}$

\begin{tabular}{|c|c|c|c|c|c|}
\hline Variáveis & $\begin{array}{l}(1) \\
Y\end{array}$ & $\begin{array}{l}(2) \\
\text { INF }\end{array}$ & $\begin{array}{c}(3) \\
\mathrm{E}\end{array}$ & $\begin{array}{c}(4) \\
\text { EMBI }\end{array}$ & $\begin{array}{c}\text { (5) } \\
\text { । }\end{array}$ \\
\hline$Y(-1)$ & $\begin{array}{c}0.619^{\star \star *} \\
(0.201)\end{array}$ & $\begin{array}{c}0.0932 \\
(0.0698)\end{array}$ & & & $\begin{array}{c}0.444^{\star * *} \\
(0.111)\end{array}$ \\
\hline L.jurosreal1 & $\begin{array}{l}-0.0267 \\
(0.0230)\end{array}$ & & $\begin{array}{l}-0.285 \\
(0.264)\end{array}$ & & \\
\hline$E(-1)$ & $\begin{array}{c}-0.0275^{\star * *} \\
(0.00979)\end{array}$ & & $\begin{array}{c}0.549^{\star \star *} \\
(0.121)\end{array}$ & & \\
\hline INF(-1) & & $\begin{array}{c}0.894^{* * *} \\
(0.113)\end{array}$ & & & $\begin{array}{l}0.373^{* * *} \\
(0.0827)\end{array}$ \\
\hline$\Delta \mathrm{E}(-1)$ & & $\begin{array}{c}6.156 \\
(3.697)\end{array}$ & & & \\
\hline EMBI(-1) & & & $\begin{array}{l}0.0172^{* * *} \\
(0.00506)\end{array}$ & $\begin{array}{c}0.354^{\star \star *} \\
(0.106)\end{array}$ & \\
\hline $\operatorname{DIV}(-1)$ & & & & $\begin{array}{l}23.63^{\star *} \\
(9.806)\end{array}$ & \\
\hline RESERVAS(-1) & & & & $\begin{array}{l}-38.01^{* *} \\
(15.95)\end{array}$ & \\
\hline TRANS(-1) & & & & $\begin{array}{c}-41.69^{\star \star \star} \\
(13.46)\end{array}$ & \\
\hline VIX & & & & $\begin{array}{l}17.82^{*} \\
(9.348)\end{array}$ & \\
\hline $\mid(-1)$ & & & & & $\begin{array}{l}0.813^{* * *} \\
(0.0345)\end{array}$ \\
\hline Constante & $\begin{array}{c}3.162^{\star \star \star} \\
(1.111)\end{array}$ & $\begin{array}{c}0.773 \\
(0.642)\end{array}$ & $\begin{array}{c}38.91^{\star \star \star} \\
(10.93)\end{array}$ & $\begin{array}{l}-874.8^{\star} \\
(484.3)\end{array}$ & \\
\hline Observations & 46 & 45 & 46 & 46 & 47 \\
\hline R-squared & 0.513 & 0.790 & 0.799 & 0.863 & 0.991 \\
\hline
\end{tabular}

Standard errors in parentheses

${ }^{* * *} p<0.01,{ }^{* *} p<0.05,{ }^{*} p<0.1$

Para as equações de Phillips e de Taylor forward-looking tentou-se ainda uma estimação por MQ2E (Mínimos Quadrados de Dois Estágios), porém os resultados não foram satisfatórios ${ }^{81}$. Em relação à curva de Phillips, tentou-se instrumentalizar a variável expectativa por defasagens da inflação, até no máximo a quarta defasagem. Para todas elas, a hipótese nula do teste de sobreidentificação dos instrumentos de Sargan foi rejeitada. Utilizando então apenas a

\footnotetext{
${ }^{80}$ Para as equações IS, Phillips e a do câmbio, foram estimados erros-padrão robustos à heteroscedasticidade, pois a hipótese nula do teste de White (erros homoscedásticos) foi rejeitada. Com exceção da equação do câmbio, as demais tiveram a hipótese nula do teste Jarque-Bera rejeitada, de maneira que os resíduos não puderam ser considerados normalmente distribuídos. Por fim, foi feito também o teste Breusch-Godfrey de autocorrelação dos resíduos para duas defasagens. Apenas a IS e a equação de Taylor tiveram a hipótese nula do teste (ausência de correlação serial) rejeitada.

${ }^{81}$ Para esta estimação, partiu-se do pressuposto de que a variável expectativa de inflação poderia estar correlacionada com o termo de erro, causando uma endogeneidade nas equações e, portanto, podendo viesar os coeficientes estimados.
} 
segunda defasagem como instrumento, embora se tenha rejeitado a hipótese nula de exogeneidade do teste de Durbin-Wu-Hausman (DWH), os coeficientes encontrados foram todos não significativos. Já em relação à equação de Taylor, utilizou-se de uma a três defasagens da inflação para instrumentalizar a variável expectativa. Em todos os modelos, não se pode rejeitar a hipótese nula do teste de DWH, de que a variável expectativa era exógena. Desta maneira, mantivemos os resultados e coeficientes das duas equações obtidos por MQO.

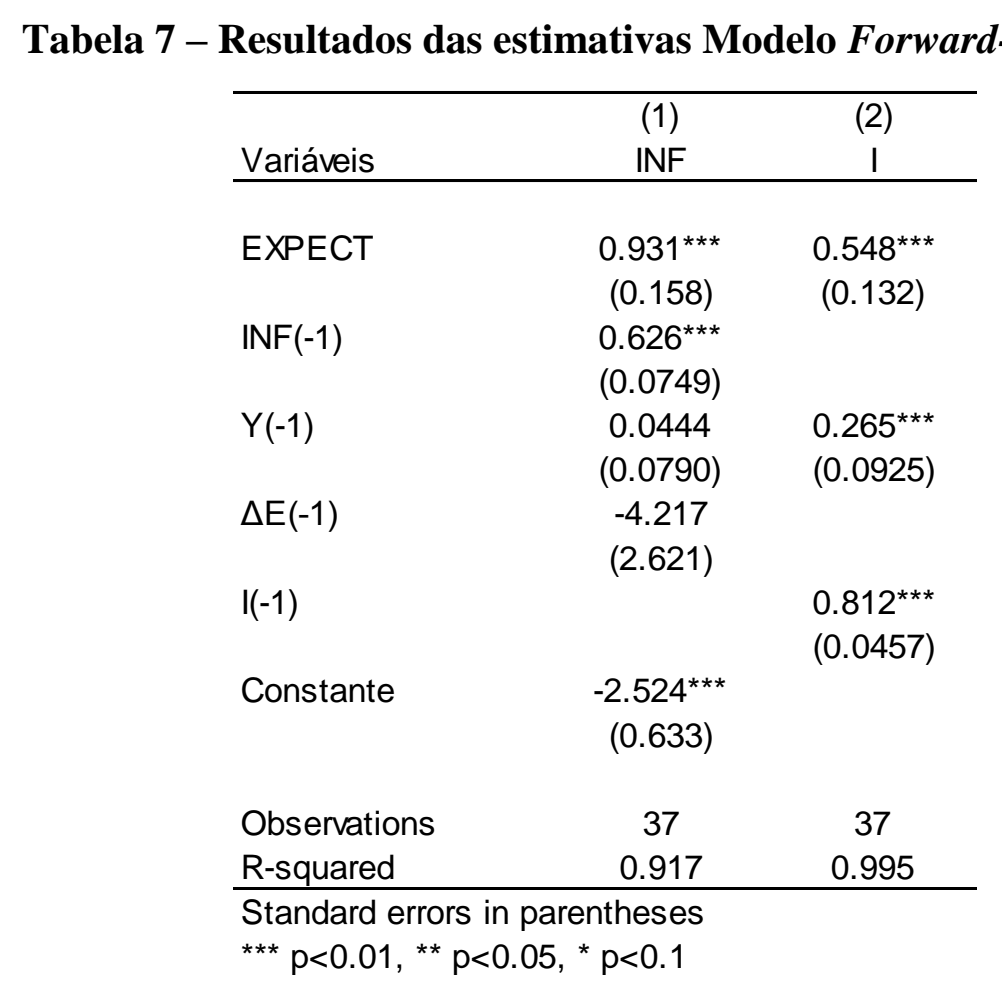

Para sumarizar a seção, as Tabelas 8 e 9 apresentam os valores estimados para cada coeficiente, bem como seu sinal esperado e seu nível de significância. Em seguida, esses valores são utilizados nos modelos da simulação.

\footnotetext{
${ }^{82}$ Para o teste de normalidade dos resíduos de Jarque-Bera, rejeitamos a hipótese nula de normalidade para a curva de Phillips ( $\mathrm{p}$-valor de 0,01) e não rejeitamos para a regra de Taylor (p-valor de 0,215). O Teste de White não apontou para heteroscedasticidade em nenhuma das equações e o de autocorrelação de Breusch-Godfrey teve os respectivos p-valores: 0,037 e 0,063 .
} 
Tabela 8 - Coeficientes Modelo Backward-Looking

\begin{tabular}{c|c|c|c}
\hline Coeficiente & $\begin{array}{c}\text { Sinal } \\
\text { esperado }\end{array}$ & Valor Estimado & Significativo? \\
\hline$\alpha_{0}$ & & 3.16 & $\mathrm{~S}(1 \%)$ \\
$\alpha_{1}$ & + & 0.62 & $\mathrm{~S}(1 \%)$ \\
$\alpha_{2}$ & - & -0.03 & $\mathrm{~N}$ \\
$\alpha_{3}$ & + & -0.03 & $\mathrm{~S}(1 \%)$ \\
$\beta_{0}$ & & 0.77 & $\mathrm{~N}$ \\
$\beta_{1}$ & + & - & - \\
$\beta_{2}$ & + & 0.89 & $\mathrm{~S}(1 \%)$ \\
$\beta_{3}$ & + & 0.09 & $\mathrm{~N}$ \\
$\beta_{4}$ & + & 6.16 & $\mathrm{~N}$ \\
$\delta_{0}$ & & 38.91 & $\mathrm{~S}(1 \%)$ \\
$\delta_{1}$ & + & 0.55 & $\mathrm{~S}(1 \%)$ \\
$\delta_{2}$ & - & -0.28 & $\mathrm{~N}$ \\
$\delta_{3}$ & + & 0.017 & $\mathrm{~S}(1 \%)$ \\
$\theta_{0}$ & & -874.82 & $\mathrm{~S}(10 \%)$ \\
$\theta_{1}$ & + & 0.35 & $\mathrm{~S}(1 \%)$ \\
$\theta_{2}$ & + & 23.63 & $\mathrm{~S}(5 \%)$ \\
$\theta_{3}$ & - & -38.01 & $\mathrm{~S}(5 \%)$ \\
$\theta_{4}$ & - & -41.69 & $\mathrm{~S}(1 \%)$ \\
$\theta_{5}$ & + & 17.82 & $\mathrm{~S}(10 \%)$ \\
$\rho$ & + & 0.81 & $\mathrm{~S}(1 \%)$ \\
$\psi$ & + & 0.37 & $\mathrm{~S}(1 \%)$ \\
$\varphi$ & + & 0.44 & $\mathrm{~S}(1 \%)$ \\
\hline
\end{tabular}

Tabela 9 - Coeficientes Modelo Forward-Looking

\begin{tabular}{c|c|c|c}
\hline Coeficiente & $\begin{array}{c}\text { Sinal } \\
\text { esperado }\end{array}$ & Valor Estimado & Significativo? \\
\hline$\beta_{0}$ & & -2.52 & $\mathrm{~S}(1 \%)$ \\
$\beta_{1}$ & + & 0.93 & $\mathrm{~S}(1 \%)$ \\
$\beta_{2}$ & + & 0.63 & $\mathrm{~S}(1 \%)$ \\
$\beta_{3}$ & + & 0.04 & $\mathrm{~N}$ \\
$\beta_{4}$ & + & -4.22 & $\mathrm{~N}$ \\
$\rho$ & + & 0.81 & $\mathrm{~S}(1 \%)$ \\
$\psi$ & + & 0.55 & $\mathrm{~S}(1 \%)$ \\
$\varphi$ & + & 0.26 & $\mathrm{~S}(1 \%)$ \\
\hline
\end{tabular}




\subsection{Exercícios de Simulação}

Após a obtenção dos parâmetros pelas diferentes estimações do modelo, torna-se possível a realização das simulações de cenários macroeconômicos. Obviamente, temos alguns problemas com os parâmetros encontrados, como o coeficiente do câmbio na curva IS. Alguns coeficientes também se mostraram insignificantes. No entanto, vamos utilizar todos os coeficientes encontrados na estimação econométrica. Assim, iremos considerar dois modelos (Backward-Looking e Forward-Looking) e, para cada um deles, faremos duas simulações (uma para a regra de Taylor estimada e outra para a regra de Taylor calibrada ${ }^{83}$ ). A regra calibrada representará uma autoridade monetária mais comprometida com a inflação e, portanto, mais austera. No total, portanto, teremos quatro modelos, sumarizados na Tabela $10^{84}$.

Como já explicado anteriormente, o exercício consiste na geração de quatro cenários macroeconômicos distintos. Para cada um deles, será analisado o comportamento de diversas carteiras de dívida. Assim, será possível construir quatro gráficos de Markowitz, relativos a cada um dos modelos. Será ainda de grande importância verificar se elas trazem, em linhas gerais, os mesmos resultados em termos de risco e retorno das carteiras.

Tabela 10 - Relação dos modelos utilizados na Simulação

\begin{tabular}{ccc}
\hline MODELO & Expectativas & Regra de Taylor \\
\hline 1 & Backward & Estimada \\
2 & Backward & Calibrada \\
3 & Forward & Estimada \\
4 & Forward & Calibrada \\
\hline
\end{tabular}

Para cada um dos modelos, os choques em cada equação têm distribuição normal, sendo que o desvio padrão é aquele encontrado para as equações estimadas (foi calculado como o desvio

\footnotetext{
${ }^{83}$ A Regra de Taylor calibrada é aquela em que os parâmetros são, respectivamente, 0.5, 0.9 e 0.1; isto é, um peso maior na inflação do que no produto. Essa regra é freqüentemente encontrada na literatura.

${ }^{84}$ A resolução do modelo forward-looking, que coloca as variáveis explicadas em função apenas de variáveis defasadas, facilitando a simulação, está no anexo III.
} 
padrão dos resíduos). Ressalta-se ainda que os valores iniciais utilizados foram aqueles referente aos últimos períodos dos dados amostrais ${ }^{85}$.

As hipóteses adotadas em relação ao superávit primário, crescimento econômico, prazo e demanda pelos títulos foram:

- Superávit Primário: 3\% do PIB

- Crescimento Econômico: $4 \%^{86}$

- Títulos com maturidade de 3 meses, sem cupom.

- Demanda existente para todos os tipos de títulos, sem alteração de preço.

Para cada modelo, a simulação foi feita 5.000 vezes para 20 períodos à frente. Ao final deste período, foram obtidas 5.000 trajetórias para as variáveis macroeconômicas ${ }^{87}$. Em cada um dos modelos, a evolução da dívida foi calculada para vinte e quatro diferentes carteiras ${ }^{88}$. Ao final do período simulado, foi calculada, para cada carteira, a média dos 5.000 caminhos para a dívida, bem como seu desvio padrão. Essas medidas podem ser consideradas como o retorno e o risco da carteira, sendo que o maior retorno é aquele que fornece a menor relação dívida/PIB (o valor inicial foi da relação Dívida/PIB foi de 41,5\% do PIB - valor de junho de 2010).

Na próxima seção são apresentados os resultados das simulações em cada um dos modelos.

\subsection{Análise da Dívida e Resultados}

Os valores médios e do desvio-padrão das variáveis macroeconômicas são apresentadas, para cada modelo, na Tabela 11. Os resultados relativos à dívida em cada modelo são apresentados separadamente, nas subseções seguintes.

\footnotetext{
${ }^{85}$ Os valores iniciais foram os mesmos para os quatro modelos, a saber: $-1,82 ; 4,6 ; 80,220$ e 8,65, denotando, respectivamente, hiato, inflação, câmbio, risco país e juros. As reservas foram estabelecidas em $12 \%$ do PIB (média dos valores recentes), o saldo em transações correntes em -1\% do PIB e o valor do VIX em 24 pontos (última observação).

${ }^{86}$ A partir da interpolação da tendência do PIB, utilizada para calcular o hiato, vamos considerar um crescimento econômico de $4 \%$ ao ano - o $g$ da equação de movimento na pág. 61 .

${ }^{87}$ É importante ressaltar que o objetivo da dissertação não foi prever com exatidão o comportamento das variáveis macroeconômicas, mesmo porque isso seria uma tarefa bastante difícil. O objetivo da geração de cenários foi apenas usá-los como ferramenta para estudar o comportamento da dívida pública para diferentes composições desta.

${ }^{88}$ Uma das limitações do modelo se refere à composição da dívida ser constante ao longo do tempo. Porém, isso pode ser contornado com o argumento de que se busca uma carteira de longo prazo.
} 
Tabela 11 - Cenários econômicos resultantes da simulação para os 4 Modelos Utilizados

\begin{tabular}{|c|c|c|c|c|}
\hline & Modelo 1 & Modelo 2 & Modelo 3 & Modelo 4 \\
\hline \multicolumn{5}{|c|}{ Valores Finais (Média) } \\
\hline Hiato & 0.36 & 0.70 & 0.37 & 1.29 \\
\hline Inflação & 7.69 & 7.79 & 4.55 & 4.42 \\
\hline Câmbio & 94.33 & 90.61 & 92.17 & 83.57 \\
\hline Risco & 377.75 & 230.76 & 325.22 & -43.41 \\
\hline Juros & 15.75 & 13.99 & 13.78 & 8.25 \\
\hline \multicolumn{5}{|c|}{ Valores Finais (Desvio Padrão) } \\
\hline Hiato & 2.03 & 2.05 & 1.95 & 1.95 \\
\hline Inflação & 3.15 & 3.17 & 1.63 & 1.62 \\
\hline Câmbio & 11.38 & 11.32 & 9.48 & 8.98 \\
\hline Risco & 260.91 & 242.58 & 113.64 & 46.65 \\
\hline Juros & 6.00 & 5.60 & 2.65 & 2.08 \\
\hline
\end{tabular}

\subsubsection{Modelo 1 - Backward-Looking com Regra de Juros Estimada}

Considerando as carteiras de canto (ou puras, com $100 \%$ de títulos iguais - carteiras 1 a 4), pela Tabela 12, o menor custo esperado é o da carteira indexada ao câmbio $(0,4742)$, seguida da prefixada $(0,4773)$, pela indexada aos juros $(0,4787)$ e pela indexada aos preços $(0,4801)$. Em relação ao risco, seu menor valor foi encontrado para a carteira prefixada $(0,0806)$, seguida da carteira indexada aos juros $(0,0862)$, indexada aos preços $(0,0873)$ e ao câmbio $(0,2108)$.

As carteiras com $100 \%$ de prefixados que incluem prêmios de até $1 \%$ ao ano (carteiras 10 a 12) conseguem ter um risco menor do que a carteira com $100 \%$ de títulos indexados aos preços e aos juros, porém, com um custo maior.

Carteiras diversificadas que contém alta parcela de títulos cambiais (carteiras 5, 7, 8, 16 e 21) são bem mais arriscadas, influenciadas pelo risco cambial, mas também tem custo esperado menor. 
Dentre as carteiras híbridas (formadas por mais de um tipo de título), se destacam as de número $6,17,18,19$ e 22, que apresentam um risco menor do que as carteiras de canto (com exceção da de $100 \%$ prefixada), com custos esperados relativamente baixos ${ }^{89}$.

Tabela 12 - Resultados da Simulação Modelo 1

\begin{tabular}{|c|c|c|c|c|c|c|c|}
\hline \multirow{2}{*}{ CARTEIRA } & \multirow{2}{*}{$\begin{array}{c}\text { Prêmio } \\
\text { Pré (pp. } \\
\text { Aa.) }\end{array}$} & \multicolumn{4}{|c|}{ COMPOSIÇÃO } & \multirow{2}{*}{ MÉDIA } & \multirow{2}{*}{$\begin{array}{l}\text { DESVIO } \\
\text { PADRÃO }\end{array}$} \\
\hline & & Selic & Câmbio & Inflação & Pré & & \\
\hline C 1 & 0 & 1 & 0 & 0 & 0 & 0.4787 & 0.0862 \\
\hline C 2 & 0 & 0 & 1 & 0 & 0 & 0.4742 & 0.2108 \\
\hline C 3 & 0 & 0 & 0 & 1 & 0 & 0.4801 & 0.0873 \\
\hline C 4 & 0 & 0 & 0 & 0 & 1 & 0.4773 & 0.0806 \\
\hline C 5 & 0 & 0.5 & 0.5 & 0 & 0 & 0.4753 & 0.1250 \\
\hline C 6 & 0 & 0.5 & 0 & 0.5 & 0 & 0.4781 & 0.0846 \\
\hline C 7 & 0 & 0 & 0.5 & 0.5 & 0 & 0.4750 & 0.1271 \\
\hline C 8 & 0 & $1 / 3$ & $1 / 3$ & $1 / 3$ & 0 & 0.4746 & 0.1042 \\
\hline C 9 & 0 & 0.25 & 0.25 & 0.25 & 0.25 & 0.4770 & 0.0938 \\
\hline C 10 & 0.25 & 0 & 0 & 0 & 1 & 0.4849 & 0.0830 \\
\hline C 11 & 0.5 & 0 & 0 & 0 & 1 & 0.4913 & 0.0836 \\
\hline C 12 & 1 & 0 & 0 & 0 & 1 & 0.5065 & 0.0849 \\
\hline C 13 & 2 & 0 & 0 & 0 & 1 & 0.5377 & 0.0909 \\
\hline C 14 & 0.25 & 0.25 & 0.25 & 0.25 & 0.25 & 0.4829 & 0.0951 \\
\hline C 15 & 0.25 & 0.5 & 0 & 0 & 0.5 & 0.4838 & 0.0852 \\
\hline C 16 & 0.25 & 0 & 0.5 & 0 & 0.5 & 0.4831 & 0.1260 \\
\hline C 17 & 0.25 & 0 & 0 & 0.5 & 0.5 & 0.4797 & 0.0828 \\
\hline C 18 & 0 & 0.31 & 0.06 & 0.27 & 0.36 & 0.4775 & 0.0832 \\
\hline C 19 & 0.25 & 0.31 & 0.06 & 0.27 & 0.36 & 0.4783 & 0.0833 \\
\hline C 20 & 0.5 & 0.31 & 0.06 & 0.27 & 0.36 & 0.4842 & 0.0841 \\
\hline C 21 & 0 & 0 & $1 / 3$ & $1 / 3$ & $1 / 3$ & 0.4765 & 0.1036 \\
\hline C 22 & 0 & $1 / 3$ & 0 & $1 / 3$ & $1 / 3$ & 0.4771 & 0.0823 \\
\hline C 23 & 0 & 0 & 0 & 0.5 & 0.5 & 0.4793 & 0.0852 \\
\hline C 24 & 0 & 0.5 & 0 & 0 & 0.5 & 0.4806 & 0.0834 \\
\hline
\end{tabular}

\subsubsection{Modelo 2 - Backward-Looking com Regra de Juros Calibrada}

Considerando as carteiras de canto (carteiras 1 a 4), pela Tabela 13, o menor custo esperado é o da carteira indexada ao câmbio $(0,4304)$, seguida da prefixada $(0,4324)$, pela indexada aos juros $(0,4325)$ e pela indexada aos preços $(0,4343)$. Em relação ao risco, seu menor valor foi

\footnotetext{
${ }^{89} \mathrm{O}$ gráfico de Markowitz, que distribui as carteiras com base no risco e retorno de cada uma, está no anexo IV, para cada um dos quatro modelos.
} 
encontrado para a carteira prefixada $(0,0714)$, seguida da carteira indexada aos juros $(0,0742)$, indexada aos preços $(0,0793)$ e ao câmbio $(0,2148)$.

Tabela 13 - Resultados da Simulação Modelo 2

\begin{tabular}{|c|c|c|c|c|c|c|c|}
\hline \multirow{2}{*}{ CARTEIRA } & \multirow{2}{*}{$\begin{array}{c}\text { Prêmio } \\
\text { Pré (pp. } \\
\text { Aa.) }\end{array}$} & \multicolumn{4}{|c|}{ COMPOSIÇÃO } & \multirow{2}{*}{ MÉDIA } & \multirow{2}{*}{$\begin{array}{l}\text { DESVIO } \\
\text { PADRÃOO }\end{array}$} \\
\hline & & Selic & Câmbio & Inflação & Pré & & \\
\hline C 1 & 0 & 1 & 0 & 0 & 0 & 0.4325 & 0.0742 \\
\hline C 2 & 0 & 0 & 1 & 0 & 0 & 0.4304 & 0.2148 \\
\hline C 3 & 0 & 0 & 0 & 1 & 0 & 0.4343 & 0.0793 \\
\hline C 4 & 0 & 0 & 0 & 0 & 1 & 0.4324 & 0.0714 \\
\hline C 5 & 0 & 0.5 & 0.5 & 0 & 0 & 0.4323 & 0.1209 \\
\hline C 6 & 0 & 0.5 & 0 & 0.5 & 0 & 0.4321 & 0.0748 \\
\hline C 7 & 0 & 0 & 0.5 & 0.5 & 0 & 0.4329 & 0.1273 \\
\hline C 8 & 0 & $1 / 3$ & $1 / 3$ & $1 / 3$ & 0 & 0.4330 & 0.0993 \\
\hline C 9 & 0 & 0.25 & 0.25 & 0.25 & 0.25 & 0.4321 & 0.0885 \\
\hline C 10 & 0.25 & 0 & 0 & 0 & 1 & 0.4405 & 0.0734 \\
\hline C 11 & 0.5 & 0 & 0 & 0 & 1 & 0.4455 & 0.0738 \\
\hline C 12 & 1 & 0 & 0 & 0 & 1 & 0.4593 & 0.0753 \\
\hline C 13 & 2 & 0 & 0 & 0 & 1 & 0.4892 & 0.0811 \\
\hline C 14 & 0.25 & 0.25 & 0.25 & 0.25 & 0.25 & 0.4351 & 0.0902 \\
\hline C 15 & 0.25 & 0.5 & 0 & 0 & 0.5 & 0.4363 & 0.0737 \\
\hline C 16 & 0.25 & 0 & 0.5 & 0 & 0.5 & 0.4364 & 0.1226 \\
\hline C 17 & 0.25 & 0 & 0 & 0.5 & 0.5 & 0.4375 & 0.0751 \\
\hline C 18 & 0 & 0.31 & 0.06 & 0.27 & 0.36 & 0.4339 & 0.0753 \\
\hline C 19 & 0.25 & 0.31 & 0.06 & 0.27 & 0.36 & 0.4345 & 0.0757 \\
\hline C 20 & 0.5 & 0.31 & 0.06 & 0.27 & 0.36 & 0.4363 & 0.0764 \\
\hline C 21 & 0 & 0 & $1 / 3$ & $1 / 3$ & $1 / 3$ & 0.4305 & 0.0985 \\
\hline C 22 & 0 & $1 / 3$ & 0 & $1 / 3$ & $1 / 3$ & 0.4319 & 0.0739 \\
\hline C 23 & 0 & 0 & 0 & 0.5 & 0.5 & 0.4338 & 0.0751 \\
\hline C 24 & 0 & 0.5 & 0 & 0 & 0.5 & 0.4306 & 0.0733 \\
\hline
\end{tabular}

As carteiras com $100 \%$ de prefixados que incluem prêmios de até $0,5 \%$ ao ano (carteiras 10 e 11) conseguem ter um risco menor do que a carteira com $100 \%$ de títulos indexados aos preços e aos juros, porém, com um custo maior.

Carteiras diversificadas que contém alta parcela de títulos cambiais (carteiras 5, 7, 8, 16 e 21) são bem mais arriscadas, influenciadas pelo risco cambial, mas também tem custo esperado menor. 
Dentre as carteiras híbridas, se destacam as de número 22 e 24, que conseguem ter custos e riscos menores do que as carteiras de canto (com exceção do risco da prefixada) e a 6 , apresenta um custo menor, com um risco relativamente baixo. Em relação ao modelo anterior, percebe-se que um cenário de menores taxas de juros e menores riscos das taxas de juros (indicadas pelo menor desvio padrão) favoreceu a presença deste indexador nas carteiras mais eficientes. Em todo caso, carteiras com títulos prefixados sem prêmio, como esperado, compõem a maioria das carteiras mais eficientes.

\subsubsection{Modelo 3 - Forward-Looking com Regra de Juros Estimada}

Considerando as carteiras de canto (carteiras 1 a 4), pela Tabela 14, o menor custo esperado é o da carteira indexada ao câmbio $(0,4546)$, seguida pela indexada aos preços $(0,4577)$, pela prefixada $(0,4584)$ e pela indexada aos juros $(0,4586)$. Em relação ao risco, seu menor valor foi encontrado para a carteira indexada aos preços $(0,0275)$, seguida pela prefixada $(0,0294)$, indexada aos juros $(0,0338)$, e ao câmbio $(0,1950)$.

As carteiras com $100 \%$ de prefixados que incluem prêmios de até $2 \%$ ao ano (carteiras 10 a 13) conseguem ter um risco menor do que a carteira com $100 \%$ de títulos indexados aos juros, porém, com um custo maior.

Carteiras diversificadas que contém alta parcela de títulos cambiais (carteiras 5, 7, 8, 16 e 21) são bem mais arriscadas, influenciadas pelo risco cambial, mas em alguns casos tem custo esperado levemente menor.

Dentre as carteiras híbridas, nenhuma conseguiu obter risco menor que a carteira $100 \%$ indexada nos preços. Algumas conseguiram ter um custo esperado menor que esta, porém, com risco consideravelmente maior, com exceção da carteira 23. Assim, fora a carteira 3, podemos citar como destaque as carteiras 4, 6, 22, 23 e 24, sendo todas elas, com exceção da 4 e 24, compostas por alta parcela de títulos indexados aos preços.

\subsubsection{Modelo 4 - Forward-Looking com Regra de Juros Calibrada}

Considerando as carteiras de canto (carteiras 1 a 4), pela Tabela 15, o menor custo esperado é o da carteira indexada aos preços e da prefixada $(0,3463)$, seguida pela indexada aos juros $(0,3466)$ e pela indexada aos câmbio $(0,3474)$. Em relação ao risco, seu menor valor foi 
encontrado para a carteira indexada aos preços $(0,0064)$, seguida pela prefixada $(0,0095)$, indexada aos juros $(0,0129)$, e ao câmbio $(0,1616)$.

Tabela 14 - Resultados da Simulação Modelo 3

\begin{tabular}{|c|c|c|c|c|c|c|c|}
\hline \multirow{2}{*}{ CARTEIRA } & \multirow{2}{*}{$\begin{array}{c}\text { Prêmio } \\
\text { Pré (pp. } \\
\text { Aa.) }\end{array}$} & \multicolumn{4}{|c|}{ COMPOSIÇÃO } & \multirow{2}{*}{ MÉDIA } & \multirow{2}{*}{$\begin{array}{l}\text { DESVIO } \\
\text { PADRÃOO }\end{array}$} \\
\hline & & Selic & Câmbio & Inflação & Pré & & \\
\hline C 1 & 0 & 1 & 0 & 0 & 0 & 0.4586 & 0.0338 \\
\hline $\mathrm{C} 2$ & 0 & 0 & 1 & 0 & 0 & 0.4546 & 0.1950 \\
\hline C 3 & 0 & 0 & 0 & 1 & 0 & 0.4577 & 0.0275 \\
\hline C 4 & 0 & 0 & 0 & 0 & 1 & 0.4584 & 0.0294 \\
\hline C 5 & 0 & 0.5 & 0.5 & 0 & 0 & 0.4581 & 0.1038 \\
\hline C 6 & 0 & 0.5 & 0 & 0.5 & 0 & 0.4580 & 0.0304 \\
\hline C 7 & 0 & 0 & 0.5 & 0.5 & 0 & 0.4567 & 0.1007 \\
\hline C 8 & 0 & $1 / 3$ & $1 / 3$ & $1 / 3$ & 0 & 0.4567 & 0.0698 \\
\hline C 9 & 0 & 0.25 & 0.25 & 0.25 & 0.25 & 0.4580 & 0.0556 \\
\hline C 10 & 0.25 & 0 & 0 & 0 & 1 & 0.4652 & 0.0298 \\
\hline C 11 & 0.5 & 0 & 0 & 0 & 1 & 0.4720 & 0.0308 \\
\hline C 12 & 1 & 0 & 0 & 0 & 1 & 0.4857 & 0.0311 \\
\hline C 13 & 2 & 0 & 0 & 0 & 1 & 0.5150 & 0.0323 \\
\hline C 14 & 0.25 & 0.25 & 0.25 & 0.25 & 0.25 & 0.4588 & 0.0559 \\
\hline C 15 & 0.25 & 0.5 & 0 & 0 & 0.5 & 0.4616 & 0.0319 \\
\hline C 16 & 0.25 & 0 & 0.5 & 0 & 0.5 & 0.4591 & 0.1013 \\
\hline C 17 & 0.25 & 0 & 0 & 0.5 & 0.5 & 0.4610 & 0.0283 \\
\hline C 18 & 0 & 0.31 & 0.06 & 0.27 & 0.36 & 0.4582 & 0.0309 \\
\hline C 19 & 0.25 & 0.31 & 0.06 & 0.27 & 0.36 & 0.4598 & 0.0313 \\
\hline C 20 & 0.5 & 0.31 & 0.06 & 0.27 & 0.36 & 0.4631 & 0.0319 \\
\hline C 21 & 0 & 0 & $1 / 3$ & $1 / 3$ & $1 / 3$ & 0.4571 & 0.0695 \\
\hline C 22 & 0 & $1 / 3$ & 0 & $1 / 3$ & $1 / 3$ & 0.4579 & 0.0304 \\
\hline C 23 & 0 & 0 & 0 & 0.5 & 0.5 & 0.4571 & 0.0284 \\
\hline C 24 & 0 & 0.5 & 0 & 0 & 0.5 & 0.4577 & 0.0313 \\
\hline
\end{tabular}

As carteiras com $100 \%$ de prefixados que incluem prêmios de até $2 \%$ (carteiras 10 a 12) ao ano conseguem ter um risco menor do que a carteira com 100\% de títulos indexados aos juros, porém, com um custo maior.

Carteiras diversificadas que contém alta parcela de títulos cambiais (carteiras 5, 7, 8, 16 e 21) são bem mais arriscadas, influenciadas pelo risco cambial e, ao contrário dos modelos anteriores, na maioria dos casos tem também custo esperado mais alto. 
Dentre as carteiras híbridas, nenhuma conseguiu obter risco menor que a carteira $100 \%$ indexada nos preços. Algumas conseguiram ter um custo esperado menor que esta, porém, com risco consideravelmente maior. Fora a carteira 3, ainda podemos citar como destaque as carteiras 4, 6, 22 e 23, sendo todas elas, com exceção da 4, compostas por alta parcela de títulos indexados aos preços.

Tabela 15 - Resultados da Simulação Modelo 4

\begin{tabular}{|c|c|c|c|c|c|c|c|}
\hline \multirow{2}{*}{ CARTEIRA } & \multirow{2}{*}{$\begin{array}{c}\text { Prêmio } \\
\text { Pré (pp. } \\
\text { Aa.) }\end{array}$} & \multicolumn{4}{|c|}{ COMPOSIÇÃO } & \multirow{2}{*}{ MÉDIA } & \multirow{2}{*}{$\begin{array}{l}\text { DESVIO } \\
\text { PADRÃOO }\end{array}$} \\
\hline & & Selic & Câmbio & Inflação & Pré & & \\
\hline C 1 & 0 & 1 & 0 & 0 & 0 & 0.3466 & 0.0129 \\
\hline C 2 & 0 & 0 & 1 & 0 & 0 & 0.3474 & 0.1616 \\
\hline C 3 & 0 & 0 & 0 & 1 & 0 & 0.3463 & 0.0064 \\
\hline C 4 & 0 & 0 & 0 & 0 & 1 & 0.3463 & 0.0095 \\
\hline C 5 & 0 & 0.5 & 0.5 & 0 & 0 & 0.3471 & 0.0828 \\
\hline C 6 & 0 & 0.5 & 0 & 0.5 & 0 & 0.3466 & 0.0094 \\
\hline C 7 & 0 & 0 & 0.5 & 0.5 & 0 & 0.3484 & 0.0836 \\
\hline C 8 & 0 & $1 / 3$ & $1 / 3$ & $1 / 3$ & 0 & 0.3452 & 0.0568 \\
\hline C 9 & 0 & 0.25 & 0.25 & 0.25 & 0.25 & 0.3460 & 0.0426 \\
\hline C 10 & 0.25 & 0 & 0 & 0 & 1 & 0.3519 & 0.0097 \\
\hline C 11 & 0.5 & 0 & 0 & 0 & 1 & 0.3574 & 0.0098 \\
\hline C 12 & 1 & 0 & 0 & 0 & 1 & 0.3686 & 0.0099 \\
\hline C 13 & 2 & 0 & 0 & 0 & 1 & 0.3920 & 0.0106 \\
\hline C 14 & 0.25 & 0.25 & 0.25 & 0.25 & 0.25 & 0.3477 & 0.0431 \\
\hline C 15 & 0.25 & 0.5 & 0 & 0 & 0.5 & 0.3493 & 0.0111 \\
\hline C 16 & 0.25 & 0 & 0.5 & 0 & 0.5 & 0.3480 & 0.0820 \\
\hline C 17 & 0.25 & 0 & 0 & 0.5 & 0.5 & 0.3491 & 0.0078 \\
\hline C 18 & 0 & 0.31 & 0.06 & 0.27 & 0.36 & 0.3464 & 0.0138 \\
\hline C 19 & 0.25 & 0.31 & 0.06 & 0.27 & 0.36 & 0.3484 & 0.0141 \\
\hline C 20 & 0.5 & 0.31 & 0.06 & 0.27 & 0.36 & 0.3504 & 0.0141 \\
\hline C 21 & 0 & 0 & $1 / 3$ & $1 / 3$ & $1 / 3$ & 0.3465 & 0.0548 \\
\hline C 22 & 0 & $1 / 3$ & 0 & $1 / 3$ & $1 / 3$ & 0.3467 & 0.0094 \\
\hline C 23 & 0 & 0 & 0 & 0.5 & 0.5 & 0.3465 & 0.0079 \\
\hline C 24 & 0 & 0.5 & 0 & 0 & 0.5 & 0.3464 & 0.0110 \\
\hline
\end{tabular}

\subsubsection{Resultados Comparados}

Em relação às carteiras de canto (carteiras 1 a 4), os menores riscos nos modelos backwardlooking foram das carteiras de títulos prefixados, seguido por indexados a juros, inflação e câmbio. Já nos modelos forward-looking, os menores riscos foram da carteira de títulos 
indexados aos preços, seguida pelas carteiras de prefixados, juros e câmbio. Estes resultados podem ser vistos na Tabela 16.

Tabela 16 - Menores Riscos: Carteiras puras

\begin{tabular}{ccccc}
\hline MODELO & 1 & 2 & 3 & 4 \\
\hline Menor Risco & Pré & Pré & Inflação & Inflação \\
V & Juros & Juros & Pré & Pré \\
V & Inflação & Inflação & Juros & Juros \\
Maior Risco & Câmbio & Câmbio & Câmbio & Câmbio \\
\hline
\end{tabular}

Ainda em relação às carteiras de canto, os menores custos esperados, dentro dos modelos backward-looking, foram da carteira indexada ao câmbio, seguida da prefixada, indexada aos juros e aos preços. Nos modelos forward-looking, houve uma diferença: enquanto o modelo 3 apontou o menor custo esperado para a carteira indexada ao câmbio, seguida da indexada aos preços, prefixadas e indexada aos juros, o modelo 4 apontou o menor custo para a carteira indexada aos preços e prefixada, seguidas pela indexada aos juros e ao câmbio. A Tabela 17 sumariza esses resultados.

Tabela 17 - Menores Custos: Carteiras puras

\begin{tabular}{ccccc}
\hline MODELO & 1 & 2 & 3 & 4 \\
\hline Menor Custo & Câmbio & Câmbio & Câmbio & Pré / Inflação \\
V & Pré & Pré & Inflação & - \\
V & Juros & Juros & Pré & Juros \\
Maior Custo & Inflação & Inflação & Juros & Câmbio \\
\hline
\end{tabular}

Desta maneira, nota-se que, dentre as carteiras de canto, o menor custo esperado sempre foi da carteira $100 \%$ indexada ao câmbio (apenas uma exceção). Por outro lado, e conforme o 
esperado, o maior risco também sempre foi desta carteira. Ressalta-se ainda que esses resultados se mantém mesmo quando são consideradas todas as carteiras incluídas no estudo.

Assim, analisando ainda as carteiras de canto, nota-se que nos modelos backward-looking há um grande destaque para a carteira com títulos prefixados, que têm o menor risco e o segundo menor custo. Para os modelos forward-looking, a carteira com títulos indexados aos preços prevalece plenamente, obtendo os menores riscos e menores custos.

Quando são verificados os resultados englobando todas as carteiras, percebe-se que no caso dos modelos forward-looking a carteira de canto indexada à inflação é muito eficiente, podendo ser considerada a opção mais vantajosa para a autoridade fiscal. No modelo 3 ainda cabe um destaque a carteira 23, com participação dividida entre títulos indexados aos preços e títulos prefixados (sem prêmio).

Por outro lado, quando são consideradas todas as carteiras nos modelos backward-looking, a carteira com maior destaque é a de canto prefixada, apesar de haver também algumas carteiras híbridas (formadas por mais de um indexador) relevantes. No entanto, deve ser ressaltado que a carteira $100 \%$ prefixada que não paga um prêmio de risco em seus títulos são um pouco irrealistas. Dessa maneira, na prática, os modelos backward-looking indicam que carteiras híbridas são mais recomendadas para a gestão dívida, fato que pode ser observado em seus gráficos de Markowitz.

Assim, analisando os gráficos de Markowitz para os modelos backward-looking, é possível perceber um destaque para as carteiras 22 (1/3 para cada um dos indexadores, com exceção do câmbio) e 6 (50\% juros e 50\% inflação). No modelo 1 ainda são relevantes as carteiras 18 e 19 (similares à 22, sendo a 19 pagando prêmio para o título prefixado), enquanto no modelo 2 tem-se as carteiras 24 e a 1 como destaques adicionais. Em vista disso, nota-se uma diferença entre os dois modelos: apesar de ambos indicarem carteiras híbridas, o primeiro aponta para uma divisão aproximada entre títulos prefixados, indexados aos juros e indexados aos preços e o segundo indica uma presença mais robusta de títulos indexados aos juros.

De maneira geral, uma interpretação possível para os resultados apresentados acima é que em ambientes de maior previsibilidade da taxa de inflação, essa opção de indexação se mostrou com menor risco para o governo, bem como menor custo esperado. Isso também é explicado 
pelos próprios resultados dos modelos macroeconômicos, que apresentaram taxas de inflação mais baixas nos modelos forward-looking do que em todos os modelos backward-looking.

Comparando os modelos no que se refere à regra monetária adotada, os cenários macroeconômicos dos modelos com regra monetária mais austera apresentaram taxas de juros mais baixas e com menor variabilidade. Por isso, foram também observados valores bem menores para a razão Dívida/PIB. No entanto, em relação à composição da dívida, os resultados não apresentaram grande diferença nos modelos forward-looking. Um efeito que pode ser notado, no contexto dos modelos backward-looking, é o já descrito aumento de participação de títulos indexados aos juros nas carteiras eficientes do modelo com a regra de juros mais austera.

Outro ponto que é importante mencionar é que, mesmo adicionando algum prêmio aos títulos prefixados, em vários dos modelos, o risco das carteiras de canto com prefixados continuou comparativamente baixo, mesmo com o aumento do seu custo esperado. Esse ponto mostra que o gestor da dívida eventualmente pode pagar mais caro para obter um menor risco de oscilação. ${ }^{90}$

\footnotetext{
${ }^{90}$ Vale ressaltar que o mesmo exercício realizado nesse capítulo foi realizado para modelos que não apresentam a endogenização do risco país e os resultados gerais foram bastante similares.
} 


\section{CONSIDERAÇÕES FINAIS}

O objetivo desta dissertação foi estudar estratégias eficientes para a gestão da dívida pública brasileira, seguindo em busca de um benchmark para a administração da dívida pública brasileira. Para isso, foi utilizada uma metodologia recorrente na literatura, que consiste em estimar e simular a economia através de um modelo estrutural Novo-Keynesiano e, em seguida, verificar qual o comportamento da relação Dívida/PIB para vários tipos de composição da dívida.

Em relação à literatura apresentada, esta dissertação procurou enriquecer o debate ao agregar algumas características ao exercício empírico: (i) estimação e simulação com modelos forward-looking e comparação dos resultados com os obtidos em modelos backward-looking, (ii) inclusão de títulos prefixados com prêmio de risco diferenciados, (iii) definição da rentabilidade dos títulos de maneira que todos tenham a mesma rentabilidade ex-ante, (iv) estimação da regra de juros, (v) ampliação da amostra de dados e (vi) especificação do modelo de maneira a permitir um feedback entre a evolução da dívida e a evolução das outras variáveis macroeconômicas.

Os resultados obtidos na simulação dos quatro modelos trabalhados mostraram uma convergência com as políticas adotadas nos últimos anos pelo Tesouro. Corroboraram também os resultados mais gerais encontrados na literatura, que recomendam uma participação expressiva de títulos prefixados e indexados à inflação na carteira da dívida pública brasileira. Quando se considera uma economia forward-looking, o melhor para o gestor da dívida é buscar uma indexação quase completa na inflação. Ao contrário, quando se considera uma economia backward-looking, é possível reduzir riscos sem aumentar o custo esperado através da combinação de diferentes indexadores, fazendo com que eles se apresentem como hedge um do outro. Vale ressaltar que nesse caso os títulos indexados à inflação também teriam um papel importante na formação de carteiras eficientes, juntamente com os prefixados e os indexados aos juros (esses especialmente no caso de regras de juros mais austeras).

Desta maneira, o benchmark a ser perseguido pelo Tesouro depende de suas hipóteses acerca do funcionamento da economia, mais especificadamente em relação à formação das 
expectativas. Independentemente dessa premissa, no entanto, o fato é que o governo vem acertando ao aumentar a participação de títulos indexados à inflação.

Outro resultado relevante é que mesmo adicionando algum prêmio de risco aos títulos prefixados, as carteiras de canto formadas por ativos prefixados continuaram com risco comparativamente baixo, mesmo com o aumento de seu custo esperado. Tal fato indica que o gestor da dívida eventualmente pode pagar mais caro para obter um risco menor.

Considerando que os dois tipos de modelo destacaram a participação de títulos indexados à inflação, para minimizar a volatilidade orçamentária, torna-se interessante revisitar as outras vantagens de uma carteira altamente indexada aos preços, à luz das variáveis expostas no primeiro capítulo. Assim, pode-se listar (i) a sinalização de comprometimento do governo com o regime das metas de inflação, reforçando sua credibilidade; (ii) a possibilidade de aumento do prazo dos títulos, reduzindo riscos de rolagem e contribuindo para o desenvolvimento do mercado de capitais e ainda (iii) o aumento da potência da política monetária, especialmente quando se reduz a parcela indexada aos juros.

Por último, é necessário destacar as limitações práticas dos resultados. Embora seja possível conhecer estratégias mais eficientes, não podem ser negligenciadas as dificuldades práticas para a sua implementação. Em alguns momentos, o Tesouro pode ter dificuldade em colocar no mercado algum tipo de título. Além disso, as mudanças em termos de composição, em direção a um ponto mais eficiente, levam algum tempo, enquanto gradualmente vão sendo substituídos títulos no mercado. Desta forma, o mais importante é conhecer o funcionamento do modelo para que se entendam os mecanismos de formação de preço dos ativos, bem como o seu impacto no custo esperado e risco no financiamento da dívida pública. 


\section{REFERÊNCIAS}

AlESINA, A., PRATTI A., TABELliNI, G. Public Confidence and Debt Management: a Model and a Case Study of Italy. In: DORNBUSCH, R., DRAGHI, M. (Eds.). Public debt management: theory and history. Cambridge University, 1990.

ALFARO, L., KANCZUK, F. Debt Maturity: Is long term debt optimal? NBER Working Paper $n^{\circ} 13119,2007$.

ALVES, L. Brazilian Public Debt Benchmark: a long-term strategy. Minerva Paper. The George Washington University. Minerva Program, Spring, 2009. Disponível em: <http://www.gwu.edu/ ibi/minerva/Spring2009/Luiz.pdf>.

ALVES, L., SILVA, A. Planejamento Estratégico da Dívida Pública Federal. In: Dívida Pública: a experiência brasileira / Anderson Silva, Lena Carvalho, Otavio de Medeiros (orgs). - Brasília: Secretaria do Tesouro Nacional: Banco Mundial, 2009.

BACHA, E., OLIVEIRA, L. (orgs.) Mercado de Capitais e Dívida Pública. Rio de Janeiro: Contra Capa, 2006.

BALL, L. Policy Rules for Open Economies. In Taylor, J. B, Monetary Policy Rules, pp. 127-144. The University of Chicago Press, London, 1999.

BARCINSKI, A. Risco de Taxa de Juros e a Dívida Pública Federal no Brasil Pós-Real. Dissertação de Mestrado, Departamento de Economia PUC-RIO, 1998.

BARRO, R. Are Government Bonds Net Wealth. Journal of Political Economy, vol. 82, pp.1095-1117, 1974.

BARRO, R. On the Determination of the Public Debt. Journal of Political Economy, 87: 940971, 1979.

BEVILAQUA, A., GARCIA, M. Debt management in Brazil: evaluation of the real plan and challenges ahead. International Journal of Finance \& Economics, Vol. 7, Issue 1, Pags 15 $35,2002$.

BLANCHARD, O. Fiscal Dominance and Inflation Targeting, Lessons from Brazil. Cambridge, MA: NBER, 2004. Working Paper n. 10389.

BOGDANSKI, J., TOMBINI, A., WERLANG, S. Implemeting Inflation Targeting in Brazil. Working Paper Series 01. Banco Central do Brasil, 1999.

BOHN, H. The Sustainability of Budget Deficits in a Stochastic Economy. Journal of Money, Credit and Banking, V. 27, p. 257-271, 1995.

BONOMO, M., BRITO, R. Regras Monetárias e Dinâmica Macroeconômica no Brasil: Uma Abordagem de Expectativas Racionais. Revista Brasileira de Economia, 2002. 
BORGES, D. Impactos das políticas monetária e fiscal no gerenciamento da dívida pública: uma análise macro-estrutural. Monografia premiada em $3^{\circ}$ lugar no XI Prêmio Tesouro Nacional - 2006, Ajuste Fiscal e Dívida Pública, Brasília, 2006.

BOREINSZTEIN, E., MAURO, P. Reviving the case for GDP-indexed bonds. Discussion paper, International Monetary Fund, September, 2002.

CABRAL, R., LOPES, M. et al. A Benchmark for Public Debt: The Brazilian Case. Tesouro Nacional, Departamento de Planejamento Estratégico da Dívida Pública, Brasília, 2008. Disponível em:

<http://www.iadb.org/lacdebtgroup/docs/Benchmark\%20-\%20Brazilian\%20Case.pdf>

CALVO, G., GUIDOTTI, P. Indexation and maturity of government bonds: an explanatory model. In: DORNBUSCH, R., DRAGHI, M. (Eds.). Public debt management: theory and history. Cambridge University, 1990.

CANUTO, O., SANTOS, P. Risco-soberano e Prêmios de Risco em Economias Emergentes. Ministério da Fazenda, Secretaria de Assuntos Especiais, Brasília, 2003.

CARNEIRO, D., WU, T. A qualidade da dívida pública brasileira. Texto para discussão n.9, Casa das Garças, 2005.

CARVALHO, R. A equação de Euler e a IS: estimações para o Brasil. Dissertação de Mestrado, EPGE-FGV, Rio de Janeiro, 2009.

CLARIDA, R., GALÍ, J., GERTLER, M. The Science of Monetary Police: a New Keynesian Perspective. Journal of Economic Literature, v.37, December, 1999.

CHRISTIANO, L., EICHENBAUM, M., EVANS, C. Monetary policy shocks: what have we learned and to what end? In: TAYLOR, J., WOODFORD, M. (eds.). Handbook of Macroeconomics, vol.1-A (Cap. 2). Amsterdam: North-Holland, 1999.

CHRISTIANO, L., EICHENBAUM, M., EVANS, C. Nominal Rigidities and the Dynamic Effects of a Shock to Monetary Policy. Journal of Political Economy, 113(1), Fev. 2005.

DICKEY, D., FULLER, W. Distribution of the estimators for autoregressive time series with a unit root. Journal of the American Statistical Association 74, 427-431, 1979.

DIEBOLD, F., and LI, C. Forecasting the term structure of government bond yields. Journal of Econometrics, Vol. 130, pp 337-364, 2006.

DORNBUSCH, R., DRAGHI, M. (Eds.). Public Debt Management: theory and history. Cambridge University, 1990.

ENDERS, W. Applied Econometric Time Series. New York: Wile, 1995.

GALE, D. The Efficient Design of Public Debt. In: DORNBUSCH, R., DRAGHI, M. (Eds.). Public debt management: theory and history. Cambridge University, 1990.

GIAMBIAGI, F. et al. (orgs.). Economia Brasileira Contemporânea. Rio de Janeiro: Campus, 
2005.

GIAMBIAGI, F., ALÉM, A. Finanças Públicas: Teoria e Prática no Brasil. Rio de Janeiro: Campus, 2001.

GIAVAZZI, F. e MISSALE, A. Public Debt Management in Brazil, NBER Working Paper $\mathrm{n}^{\circ}$ 10394, 2004.

GIAVAZZI, F., PAGANO, M. Confidence crises and public debt management. In: DORNBUSCH, R., DRAGHI, M. (Eds.) Public debt management: theory and history. Cambridge: Cambridge University, 1990. p.125-143.

GOLDFAJN, I. Public Debt Indexation and Denomination: The Case of Brazil. International Journal of Finance and Economics, 2000.

GOLDFAJN, I., PAULA, A. Uma Nota Sobre a Composição Ótima da Dívida Pública Reflexões para o Caso Brasileiro. Departamento de Economia PUC-RIO, texto para discussão n. $411,1999$.

HAMILTON, J.; FLAVIN, M. On the Limitations of Government Borrowing: a Framework for Empirical Testing. American Economic Review, V. 76, nº 4, set/1986.

HOOVER, K. D. The New Classical Macroeconomics. Basil Blackwell, 1988.

HULL, J. Opções, Futuros e Outros Derivativos. BM\&F, 1998.

KING, M. Commentary: Monetary policy implications of greater fiscal discipline, (In) budget deficits and debt: issues and options. Federal Reserve Bank of Kansas City. AugustSeptember, 1995. p.171-182.

KWIATKOSWKI, D., PHILLIPS, P., SCHMIDT, P., SHIN, Y. Testing the null hypothesis of stationarity against the alternative of a unit root: How sure are we that economic time series have a unit root? Journal of Econometrics 54, 159-178, 1992.

LLUSSÁ, F. Credibilidade e Administração da Dívida Pública: um estudo para o Brasil. Dissertação de Mestrado, Departamento de Economia FGV-SP, 1997.

LOPES, M., DOMINGOS, E. Composição Ótima para a Dívida Pública: Uma Análise Macro-Estrutural. Encontro Nacional de Economia - ANPEC, 2004.

MARKOWITZ. H. Portfolio Selection. Journal of Finance, junho, pp. 77 - 91, $1952 .$.

MATTOS, C. (Org.). A Dívida Pública Brasileira. Caderno de Altos Estudos. Brasília: Editora da Câmara dos Deputados, 2005.

MEGALE, C. Fatores externos e Risco País. Dissertação de Mestrado, PUC-RIO, Depto. de Economia, Rio de Janeiro, 2003. 
MENDONÇA, H. F. Independência do Banco Central e coordenação de políticas: vantagens e desvantagens de duas estruturas para estabilização. Revista de Economia Política, v.23, n.1, p.89, jan.-mar. 2003.

MENDONÇA, M., PIRES, M., MEDRANO, L. Administração e sustentabilidade da Dívida Pública no Brasil: uma análise para o período 1995-2007. Texto para discussão n. 1342. IPEA, 2008.

MISSALE, A. Public Debt Management. Oxford University Press, Oxford and New York, 1999.

MODIGLIANI, F., MILLER, M. H..The cost of capital corporation finance and the theory of investment. American Economic Review 48(3), p. 261-97, 1958.

MUINHOS, M., ALVES, S., RIELLA, G. Modelo Estrutural com Setor Externo: Endogenização do Prêmio de Risco e do Câmbio. Working Paper Series, $n^{\circ} 42$. Banco Central do Brasil, 2002.

NELSON, C., SIEGEL, A. Parsimonious modelling of yield curves. Journal of Business, Vol. 60, n. 4, 1987.

NOVAES, A. Sinopse: Tributação, alongamento da dívida pública e as Letras Financeiras do Tesouro. In: Bacha, E., OLIVEIRA, L. (orgs): Mercado de Capitais e Dívida Pública, Rio de Janeiro, 2006.

PASTORE, A. Por que a política monetária perde eficácia? Revista Brasileira de Economia, vol.50, N.3, 1996.

PEDRAS, G. História da Dívida Pública no Brasil: de 1964 até os dias atuais. In: Dívida Pública: a experiência brasileira / Anderson Silva, Lena Carvalho, Otavio de Medeiros (orgs). - Brasília: Secretaria do Tesouro Nacional: Banco Mundial, 2009.

PÊGO-FILHO, B., PINHEIRO, M. Os passivos contingentes e a dívida pública no Brasil: evolução recente (1996-2003) e perspectivas (2004-2006). Texto para discussão $n^{\circ} 1007$. Brasília: IPEA.

PICK, A., ANTHONY, M. A simulation model for the analysis of the UK's sovereign debt strategy. UK DMO Research Paper, 2006.

ROCHA, K. Estrutura institucional e eventos recentes na administração da Dívida Pública Federal. In: Dívida Pública: a experiência brasileira / Anderson Silva, Lena Carvalho, Otavio de Medeiros (orgs). - Brasília: Secretaria do Tesouro Nacional: Banco Mundial, 2009.

ROMAN, R. Dívida Pública Indexada: Aspectos Teóricos e a Experiência do Brasil no Período Pós-Real. Dissertação de Mestrado UFRJ. Instituto de Economia, 2004.

ROMER, D. Keynesian Macroeconomics without the LM curve. Cambridge: NBER Working Paper, $n^{\circ} 7461,2000$.

SANTOS, F., HOLLAND, M. Estimando a Demanda Agregada no Brasil: o papel dos fatores 
externos; Anais do XXXVI Encontro Nacional de Economia, ANPEC, 2008.

SARGENT, T., WALLACE, N. Some unpleasant monetarist arithmetic. Federal Reserve Bank of Minneapolis Quarterly Review, v.5, n.3, p.1-17, 1981.

SCHWARTZMAN, F. Estimativa de curva de Phillips para o Brasil com preços desagregados. Economia Aplicada, 10(1), jan-mar, 2006.

SECRETARIA DO TESOURO NACIONAL. Plano Anual de Financiamento. 2001 a 2010. Disponível em: <http://www.tesouro.fazenda.gov.br/divida_publica/index.asp >.

SILVA, R. e MENDONÇA, H. A importância da credibilidade para o equilíbrio fiscal: uma avaliação para o caso brasileiro. Brasília: ESAF, 2007. Monografia premiada com o terceiro lugar no XII Prêmio Tesouro Nacional - 2007. Ajuste Fiscal e Dívida Pública. Rio de Janeiro $(\mathrm{RJ})$.

SIMS, C. Interpreting the macroeconomic time series facts: the effects of monetary policy. European Economic Review, 36(5), Jun. 1992.SVENSSON, L. Open Economy Inflation Targeting. Journal of International Economics, pp. 155-183, 2000.

TAYLOR, J. The Inflation/Output Variability Trade-off Revisited, in J.C. Fuhrer (ed.), Goals, Guidelines, and Constraints Facing Monetary Policymakers, Federal Reserve Bank of Boston, 1994.

TREHAN, B. e WALSH, C. Common Trends, the Government Budget Constraint and Revenue Smoothing. Journal of Economic Dynamics and Control, V.12, p. 425-444, 1988.

VERDINI, M. Regras Monetárias e Restrição Fiscal: Uma Análise da Política de Metas para a Inflação no Brasil. Dissertação de Mestrado, Departamento de Economia EPGE, 2003.

VERSIANI, F. A dívida pública interna e sua trajetória recente. Texto para Discussão 284, Departamento de Economia, UnB, 2003.

WALLACE, N. A Modigliani-Miller theorem for open-market operations. American Economic Review, 71(3), p. 267-74, 1981.

WILCOX, D. The Sustainability of Government Deficits: Implications of the Present-Value Borrowing Constraint. Journal of Money, Credit and Banking, V.21, p. 291-306, 1989.

WOODFORD, M. Interest and Prices - foundations of a theory of monetary policy. Princeton: Princeton University Press, 2003.

YUKI, E. Uma análise em Painel dos determinantes do Risco País com um modelo de Reputação Internacional. Dissertação de Mestrado, Universidade de São Paulo, Depto. de Economia, São Paulo, 2004. 


\section{ANEXO I - RENTABILIDADE DOS ATIVOS}

A rentabilidade dos títulos foi estabelecida de maneira que a rentabilidade de todos eles seja igual ex-ante. Em outras palavras, o rendimento esperado do investidor é igual, independente do título que ele escolha (título indexado aos juros, aos preços e ao câmbio). No caso do título prefixado, quando não existir um prêmio sobre a sua remuneração, a igualdade anterior também será válida. Desta maneira, não se corre o risco de haver uma procura por apenas um tipo de título. Assim, vale notar que, sem os choques aleatórios na simulação do modelo, a rentabilidade dos títulos indexados ao câmbio, aos juros e aos preços e dos prefixados sem pagamento de prêmio seriam iguais.

\section{RENDIMENTO JUROS:}

$R_{t}^{i}=\left(1+\frac{i_{t}}{100}\right)^{\frac{1}{4}}$

\section{RENDIMENTO DE INFLAÇÃO:}

$$
\begin{aligned}
R_{t}^{\pi}= & P_{t}^{\pi} *\left(1+\frac{\pi_{t}}{100}\right)^{\frac{1}{4}}, \text { sendo que o prêmio de inflação é igual a } \\
P_{t}^{\pi}= & \frac{E_{t-1}\left(1+\frac{i_{t}}{100}\right)^{\frac{1}{4}}}{E_{t-1}\left(1+\frac{\pi_{t}}{100}\right)^{\frac{1}{4}}}
\end{aligned}
$$

RENDIMENTO CAMBIAL:

$R_{t}^{e}=P_{t}^{e} * \frac{e_{t}}{e_{t-1}}$, sendo que o prêmio cambial é igual a

$$
P_{t}^{e}=\frac{E_{t-1}\left(1+\frac{i_{t}}{100}\right)^{\frac{1}{4}}}{E_{t-1}\left(\frac{e_{t}}{e_{t-1}}\right)}
$$


RENDIMENTO PREFIXADO:

$R_{t}^{\text {pré }}=P_{t}^{\text {pré }} * E_{t-1}\left(1+\frac{i_{t}}{100}\right)^{\frac{1}{4}}$

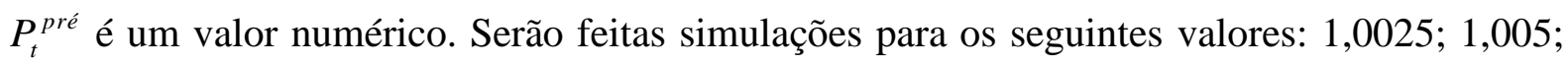

1,01 e 1,02, todos elevados a $1 / 4$, representando prêmios anuais de $0,25 \%, 0,5 \%, 1 \%$ e $2 \%$. Esses valores são foram escolhidos arbitrariamente: no início de 2010, devido ao bom momento da economia brasileira, o Tesouro conseguiu colocar no mercado títulos prefixados com prêmios entre 0,15 e 0,25 pontos percentuais ao ano (diferença entre a taxa paga pelo Tesouro e a taxa do DI de prazo equivalente). O cálculo com prêmios maiores englobaria cenários econômicos menos favoráveis à colocação de títulos no mercado por parte do Tesouro. ${ }^{91}$

\footnotetext{
${ }^{91}$ São várias as matérias que reportaram esses valores. Um exemplo é a "Fluxo Externo reduz prêmio de risco de título prefixado do Tesouro", de 08/02/2010, no Jornal do Comércio/Agência Estado.
} 


\section{ANEXO II - TESTES DE RAIZ UNITÁRIA}

Um pressuposto para a realização da análise de regressão baseada em dados de séries temporais é a exigência de que as séries do modelo sejam estacionárias. Um processo estocástico pode ser dito estacionário quando sua média e variância são constantes ao longo do tempo e quando o valor da covariância entre dois períodos de tempo depende apenas da defasagem entre os dois períodos. ${ }^{92}$ Essas propriedades estão descritas abaixo:

a) média constante: $E\left(Y_{t}\right)=\mu$

b) variância constante: $\operatorname{Var}\left(Y_{t}\right)=E\left(Y_{t}-\mu\right)=\sigma^{2}$

c) covariância depende apenas do lag entre dois períodos $\gamma_{k}=E\left[\left(Y_{t}-\mu\right)\left(Y_{t}-\mu\right)\right]$

De maneira geral, a importância das séries estacionárias reside no fato de que elas tenderão a retornar para a sua média e terão uma amplitude de flutuação ao redor desta média mais ou menos constante. Por outro lado, séries temporais não-estacionárias tem pouco valor prático para a finalidade de fazer previsões: cada conjunto de dados da série será um episódio específico, cujo comportamento só poderá ser estudado para o período considerado, impedindo a generalização para outros períodos de tempo.

Além disso, a regressão de séries temporais não-estacionárias pode gerar o problema da regressão espúria, ou seja, a regressão sem sentido. Nesse tipo de regressão, obtém-se geralmente elevados valores para o $\mathbf{R}^{2}$, mesmo que não exista nenhuma relação estatística significativa entre as variáveis do modelo. Geralmente, o $\mathrm{R}^{2}$ alto é consequência da presença de tendências, e não de uma verdadeira relação entre as variáveis. Também para este caso, devido a ausência de estacionariedade, os testes usuais $t$ e $F$ não são válidos.

Desta maneira, a primeira etapa da estimação de um modelo de séries temporais é a verificação da estacionariedade das séries. Para isso, existem os testes de raiz unitária que serão descritos a seguir. ${ }^{93}$

\footnotetext{
${ }^{92}$ Uma série com essas propriedades é identificada como sendo fracamente estacionária (ou estacionária de covariância), já que apenas os dois primeiros momentos (média e variância) de sua distribuição de probabilidade são estacionários.
} 


\section{II.1 Testes}

O teste de raiz unitária constitui em uma forma de verificar a estacionariedade das séries temporais. De maneira geral, o teste admite que a série é gerada por um processo autoregressivo de primeira ordem, $\operatorname{AR}(1)$, tal como descrito abaixo:

$$
y_{t}=\rho y_{t-1}+\varepsilon_{t}
$$

onde $\rho$ é um parâmetro que relaciona o valor presente da série ao seu valor passado e $\varepsilon_{t}$ é o termo de erro estocástico que satisfaz as hipóteses clássicas de média zero, variância constante e ausência de correlação serial. De acordo com essas hipóteses, os resíduos são considerados como ruído branco.

A estacionariedade das séries vai depender do valor encontrado para o parâmetro $\rho$. Caso $-1<\rho<1$, pode-se dizer que a série é estacionária, já que os choques vão se dissipar ao longo do tempo. Se $\rho=1$, por outro lado, diz-se que a série é não-estacionária; seus valores passados são carregados ao longo do tempo, seguindo um passeio aleatório.

Assim, o teste de raiz unitária consiste na estimação da equação (1) pelo método dos Mínimos Quadrados Ordinários (MQO) e verificar se $\rho$ é estatisticamente igual a 1. Neste caso, a hipótese nula $\left(H_{0}\right)$ considera $\rho=1$ e a hipótese alternativa $\left(H_{a}\right)$ estabelece $|\rho|<1$; deve-se, portanto, comparar a estatística $t$ obtida com os valores críticos encontrados nas tabelas de Dickey e Fuller (1979) ${ }^{94}$. Além do modelo apresentado em (1), o teste trabalha com mais dois modelos: um inclui na equação um termo de intercepto e o outro um termo de intercepto mais um termo de tendência.

Para formalizar o teste, portanto, reescrevemos a equação (1) e apresentamos os dois outros modelos. Desta forma, o teste deverá detectar a presença de raiz unitária quando a série puder ser expressa através de uma das seguintes formas:

$$
\Delta y_{t}=\alpha+\beta_{t}+\gamma y_{t-1}+\varepsilon_{t}
$$

\footnotetext{
${ }^{94}$ Em realidade, sob $\mathrm{H}_{\mathrm{o}}: \rho=1(\gamma=0)$, o valor $\mathrm{t}$ estimado do coeficiente de $\mathrm{Y}_{\mathrm{t}-1}$ se comporta segundo a estatística tau $(\tau)$, conforme é mostrado por Dickey e Fuller (1979).
} 
$\Delta y_{t}=\alpha+\gamma y_{t-1}+\varepsilon_{t}$

$\Delta y_{t}=\gamma y_{t-1}+\varepsilon_{t}$

onde $\Delta$ é o operador de primeira diferença e $\gamma=\rho-1$. Quando $\rho=1, \gamma=0$; desta maneira a hipótese nula torna-se testar $\gamma=0$. (ENDERS, 2004). Outro ponto importante é que os valores críticos do teste usado para verificar a hipótese nula diferem para cada um dos modelos acima.

O teste Dickey-Fuller (DF), representado através das equações (2), (3) e (4), pressupõe que o termo de erro é não correlacionado. Por causa disso, para casos em que o erro apresente correlação, foi desenvolvido o teste ADF (Augmented Dickey-Fuller), que aumenta as equações do teste DF a partir do acréscimo de valores defasados da variável dependente $Y_{t}$. Os procedimentos do teste ADF seguem a mesma lógica do teste DF; assim, continua sendo testada a $H_{0}: \gamma=0$ e os mesmos valores críticos do teste DF continuam valendo para o ADF.

O ADF é um teste com baixo poder, isto é, tende a não rejeitar a hipótese nula de raiz unitária. Assim, outro teste também será realizado para a verificação da estacionariedade das séries, o KPSS. Desenvolvido por Kwiatkowsky et al. (1992), este teste tem, como diferença em relação ao ADF, a inversão das hipóteses. Assim, no KPSS, a hipótese nula estabelece que a série é estacionária e a hipótese alternativa estabelece a presença de raiz unitária. O teste apresenta dois modelos (equações): um com intercepto e tendência e o outro somente com intercepto.

Para as séries trabalhadas nos modelos do capítulo 4, fizemos os dois testes, que estão nas Tabelas 16 e 17. Em alguns casos, a conclusão de um teste foi de encontro com a conclusão do outro e, para esses casos, optou-se por considerá-las como estacionárias. 
Tabela 18 - Resultados ADF

\begin{tabular}{|c|c|c|c|c|c|c|}
\hline \multirow{2}{*}{ Variável } & \multirow{2}{*}{$\begin{array}{c}\text { Número } \\
\text { Defasagens (AIC) }\end{array}$} & \multirow{2}{*}{ Modelo } & \multirow{2}{*}{$\begin{array}{c}\text { Estatística } \\
\text { ADF }\end{array}$} & \multicolumn{3}{|c|}{ Valores críticos } \\
\hline & & & & $1 \%$ & $5 \%$ & $10 \%$ \\
\hline Câmbio & 2 & Int & -0.99 & -3.59 & -2.93 & -2.60 \\
\hline Câmbio & 2 & Int + Tend & -2.09 & -4.18 & -3.52 & -3.19 \\
\hline Câmbio & 2 & Sem & -0.94 & -2.62 & -1.95 & -1.61 \\
\hline Juros reais & 2 & Int & -8.84 & -3.58 & -2.93 & -2.60 \\
\hline Juros reais & 2 & Int + Tend & -8.79 & -4.17 & -3.51 & -3.19 \\
\hline Juros reais & 2 & Sem & -4.61 & -2.62 & -1.95 & -1.61 \\
\hline Inflação & 2 & Int & -2.11 & -3.59 & -2.93 & -2.60 \\
\hline Inflação & 1 & Int + Tend & -3.92 & -4.18 & -3.51 & -3.19 \\
\hline Inflação & 2 & Sem & -0.88 & -2.62 & -1.95 & -1.61 \\
\hline Expectativas & 1 & Int & -2.99 & -3.63 & -2.95 & -2.61 \\
\hline Expectativas & 4 & Int + Tend & -2.53 & -4.27 & -3.56 & -3.21 \\
\hline Expectativas & 1 & Sem & -0.80 & -2.63 & -1.95 & -1.61 \\
\hline Hiato & 1 & Int & -4.64 & -3.58 & -2.93 & -2.60 \\
\hline Hiato & 1 & Int + Tend & -4.60 & -4.18 & -3.51 & -3.19 \\
\hline Hiato & 1 & Sem & -4.70 & -2.62 & -1.95 & -1.61 \\
\hline Embi & 0 & Int & -2.11 & -3.58 & -2.93 & -2.60 \\
\hline Embi & 0 & Int + Tend & -2.73 & -4.17 & -3.51 & -3.18 \\
\hline Embi & 0 & Sem & -1.84 & -2.62 & -1.95 & -1.61 \\
\hline Juros Nominais & 1 & Int & -2.04 & -3.58 & -2.93 & -2.60 \\
\hline Juros Nominais & 1 & Int + Tend & -3.90 & -4.17 & -3.51 & -3.19 \\
\hline Juros Nominais & 2 & Sem & -1.18 & -2.62 & -1.95 & -1.61 \\
\hline Dívida & 1 & Int & -1.18 & -3.58 & -2.93 & -2.60 \\
\hline Dívida & 1 & Int + Tend & -1.92 & -4.18 & -3.52 & -3.19 \\
\hline Dívida & 1 & Sem & -0.31 & -2.62 & -1.95 & -1.61 \\
\hline Reservas & 0 & Int & -0.79 & -3.58 & -2.93 & -2.60 \\
\hline Reservas & 0 & Int + Tend & -1.85 & -4.17 & -3.51 & -3.19 \\
\hline Reservas & 0 & Sem & 0.75 & -2.62 & -1.95 & -1.61 \\
\hline Trans & 1 & Int & -2.11 & -3.58 & -2.93 & -2.60 \\
\hline Trans & 1 & Int + Tend & -1.32 & -4.18 & -3.51 & -3.19 \\
\hline Trans & 1 & Sem & -2.01 & -2.62 & -1.95 & -1.61 \\
\hline Vix & 0 & Int & -2.96 & -3.58 & -2.93 & -2.60 \\
\hline Vix & 0 & Int + Tend & -2.94 & -4.17 & -3.51 & -3.19 \\
\hline Vix & 1 & Sem & -0.52 & -2.62 & -1.95 & -1.61 \\
\hline
\end{tabular}


Tabela 19 - Resultados KPSS

\begin{tabular}{|c|c|c|c|c|c|c|}
\hline \multirow{2}{*}{ Variável } & \multirow{2}{*}{$\begin{array}{c}\text { Número } \\
\text { Defasagens } \\
\text { (Newey-West) }\end{array}$} & \multirow{2}{*}{ Modelo } & \multirow{2}{*}{ Estatística KPSS } & \multicolumn{3}{|c|}{ Valores críticos } \\
\hline & & & & $1 \%$ & $5 \%$ & $10 \%$ \\
\hline Câmbio & 5 & Int & 0.619 & 0.739 & 0.463 & 0.347 \\
\hline Câmbio & 4 & Int + Tend & 0.147 & 0.216 & 0.146 & 0.119 \\
\hline Juros reais & 4 & Int & 0.661 & 0.739 & 0.463 & 0.347 \\
\hline Juros reais & 3 & Int + Tend & 0.106 & 0.216 & 0.146 & 0.119 \\
\hline Inflação & 5 & Int & 0.270 & 0.739 & 0.463 & 0.347 \\
\hline Inflação & 4 & Int + Tend & 0.133 & 0.216 & 0.146 & 0.119 \\
\hline Expectativas & 4 & Int & 0.461 & 0.739 & 0.463 & 0.347 \\
\hline Expectativas & 2 & Int + Tend & 0.103 & 0.216 & 0.146 & 0.119 \\
\hline Hiato & 1 & Int & 0.082 & 0.739 & 0.463 & 0.347 \\
\hline Hiato & 1 & Int + Tend & 0.048 & 0.216 & 0.146 & 0.119 \\
\hline Embi & 5 & Int & 0.668 & 0.739 & 0.463 & 0.347 \\
\hline Embi & 4 & Int + Tend & 0.087 & 0.216 & 0.146 & 0.119 \\
\hline Juros Nominais & 5 & Int & 0.745 & 0.739 & 0.463 & 0.347 \\
\hline Juros Nominais & 4 & Int + Tend & 0.078 & 0.216 & 0.146 & 0.119 \\
\hline Dívida & 5 & Int & 0.334 & 0.739 & 0.463 & 0.347 \\
\hline Dívida & 5 & Int + Tend & 0.176 & 0.216 & 0.146 & 0.119 \\
\hline Reservas & 5 & Int & 0.622 & 0.739 & 0.463 & 0.347 \\
\hline Reservas & 5 & Int + Tend & 0.125 & 0.216 & 0.146 & 0.119 \\
\hline Trans & 5 & Int & 0.421 & 0.739 & 0.463 & 0.347 \\
\hline Trans & 5 & Int + Tend & 0.200 & 0.216 & 0.146 & 0.119 \\
\hline Vix & 5 & Int & 0.135 & 0.739 & 0.463 & 0.347 \\
\hline Vix & 5 & Int + Tend & 0.135 & 0.216 & 0.146 & 0.119 \\
\hline
\end{tabular}




\section{ANEXO III - RESOLUÇÃO DO MODELO}

Para obter a resolução do modelo de expectativas racionais, transformando a equação de Phillips forward-looking em uma equação que coloca a inflação em $t$ em função apenas de variáveis defasadas, partimos da própria equação de Phillips:

$\pi_{t}=\beta_{0}+\beta_{1} E_{t} \pi_{t+1}+\beta_{2} \pi_{t-1}+\beta_{3} y_{t-1}+\beta_{4} \Delta e_{t-1}+\varepsilon_{t}^{\pi}$

Sob expectativas racionais, temos:

$\pi_{t+1}=E_{t} \pi_{t+1}+\varepsilon_{t+1}^{\pi}$

Que pode ser reescrita como:

$E_{t} \pi_{t+1}=\pi_{t+1}-\varepsilon_{t+1}^{\pi}$

Substituindo em (1), chegamos a:

$\pi_{t}=\beta_{0}+\beta_{1}\left(\pi_{t+1}-\varepsilon_{t+1}^{\pi}\right)+\beta_{2} \pi_{t-1}+\beta_{3} y_{t-1}+\beta_{4} \Delta e_{t-1}+\varepsilon_{t}^{\pi}$

Rearranjando, podemos chegar à (5):

$\beta_{1} \pi_{t+1}=-\beta_{0}+\pi_{t}+\beta_{1} \varepsilon_{t+1}^{\pi}-\beta_{2} \pi_{t-1}-\beta_{3} y_{t-1}-\beta_{4} \Delta e_{t-1}-\varepsilon_{t}^{\pi}$

$\pi_{t+1}=\frac{-\beta_{0}}{\beta_{1}}+\frac{\pi_{t}}{\beta_{1}}+\varepsilon_{t+1}^{\pi}-\frac{\beta_{2} \pi_{t-1}}{\beta_{1}}-\frac{\beta_{3} y_{t-1}}{\beta_{1}}-\frac{\beta_{4} \Delta e_{t-1}}{\beta_{1}}-\frac{\varepsilon_{t}^{\pi}}{\beta_{1}}$

$\pi_{t+1}=\theta_{0}+\theta_{1} \pi_{t}+\theta_{2} \pi_{t-1}+\theta_{3} y_{t-1}+\theta_{4} \Delta e_{t-1}+\theta_{5} \varepsilon_{t}^{\pi}+\varepsilon_{t+1}^{\pi}$,

Onde $\theta_{0}=\frac{-\beta_{0}}{\beta_{1}}, \theta_{1}=\frac{1}{\beta_{1}}, \theta_{2}=-\frac{\beta_{2}}{\beta_{1}}, \theta_{3}=-\frac{\beta_{3}}{\beta_{1}}, \theta_{4}=-\frac{\beta_{4}}{\beta_{1}}$ e $\theta_{5}=-\frac{1}{\beta_{1}}$

Iterando um período para trás, chegamos a: 
$\pi_{t}=\theta_{0}+\theta_{1} \pi_{t-1}+\theta_{2} \pi_{t-2}+\theta_{3} y_{t-2}+\theta_{4} \Delta e_{t-2}+\theta_{5} \varepsilon_{t-1}^{\pi}+\varepsilon_{t}^{\pi}$

que coloca $\pi_{t}$ em função apenas de variáveis defasadas. Essa, portanto, foi a equação utilizada na simulação. 
ANEXO IV - GRÁFICOS DE MARKOWITZ PARA OS 4 MODELOS

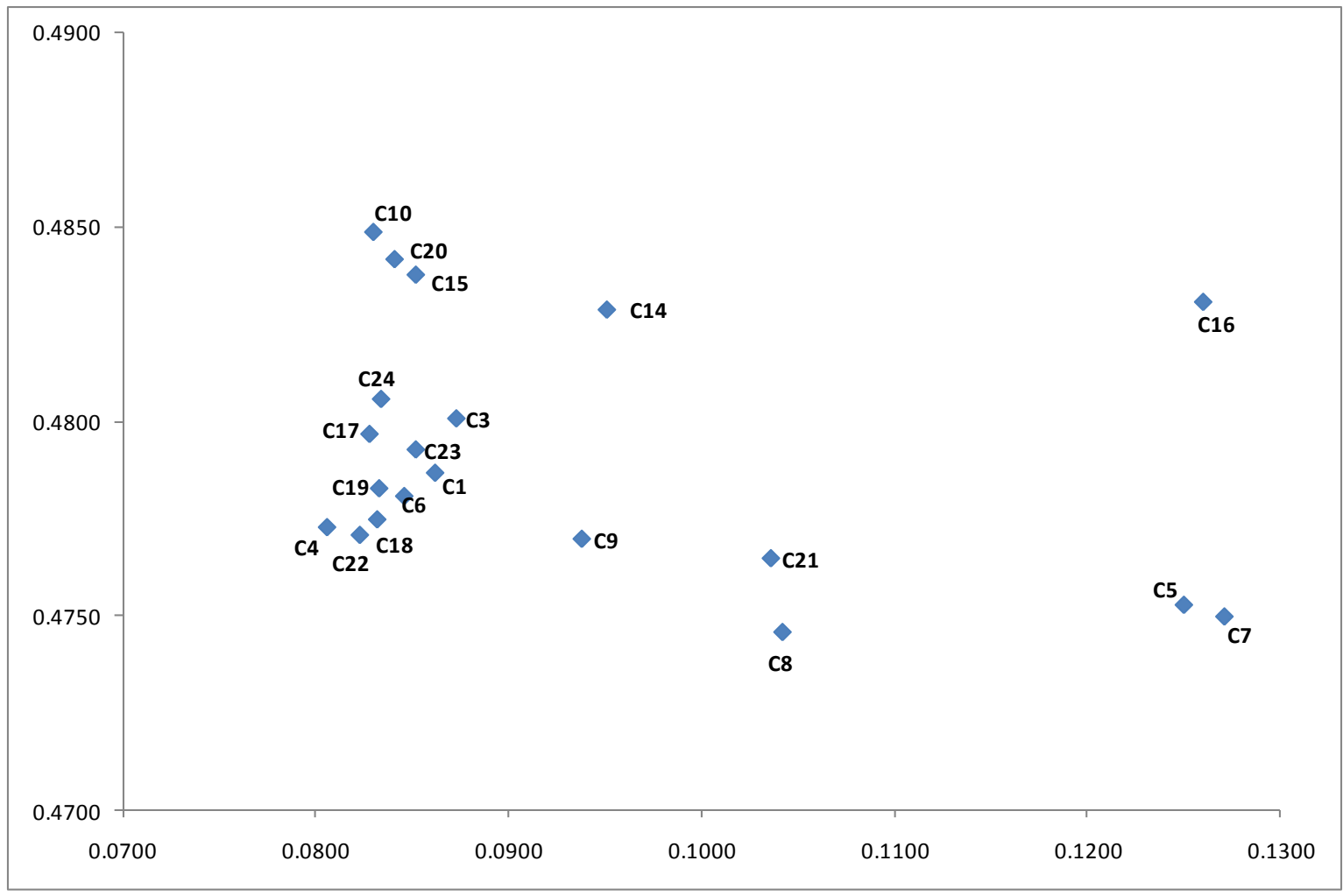

Gráfico 10 - Gráfico Markowitz: Modelo 1

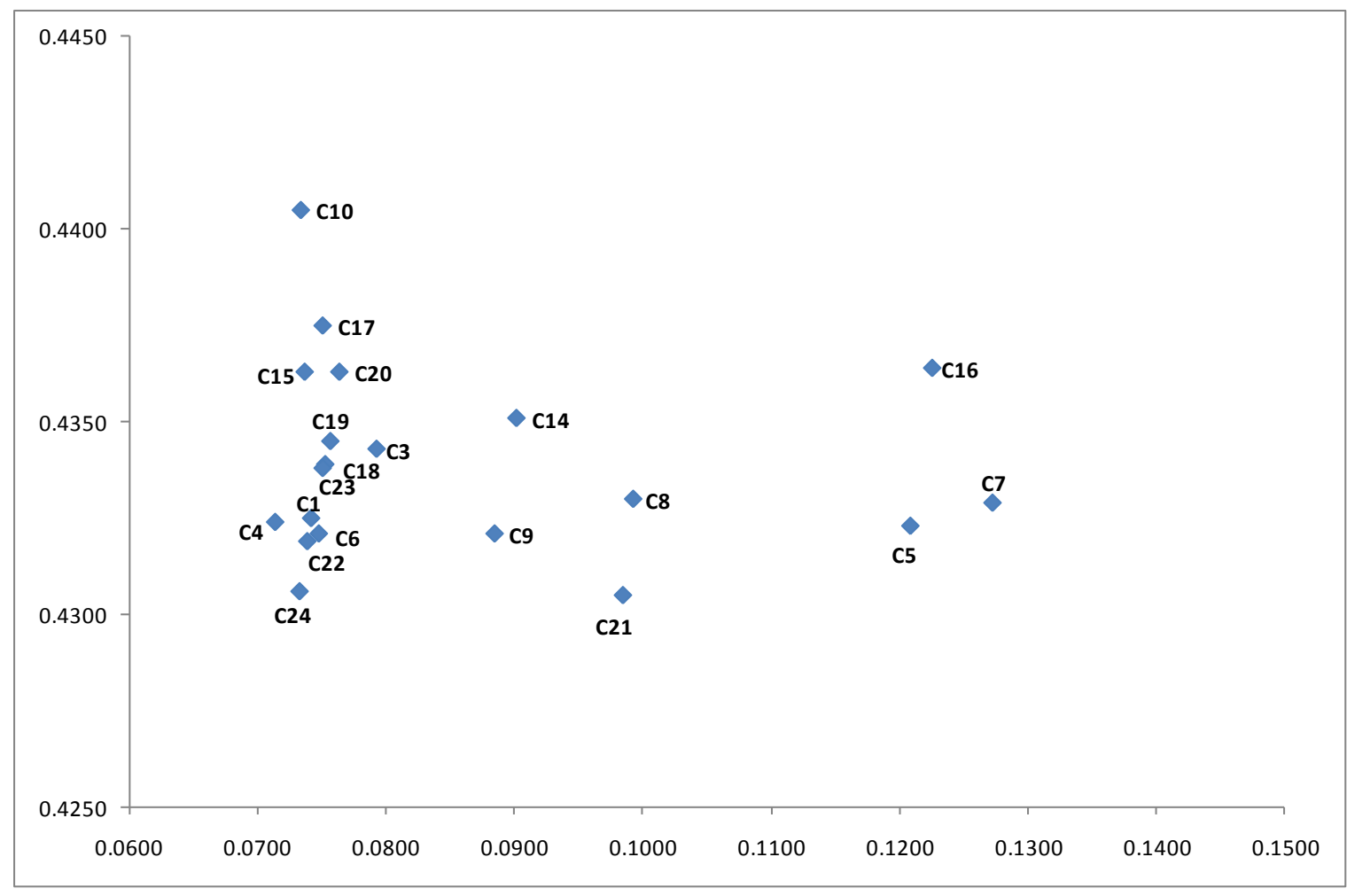

Gráfico 11 - Gráfico Markowitz: Modelo 2 


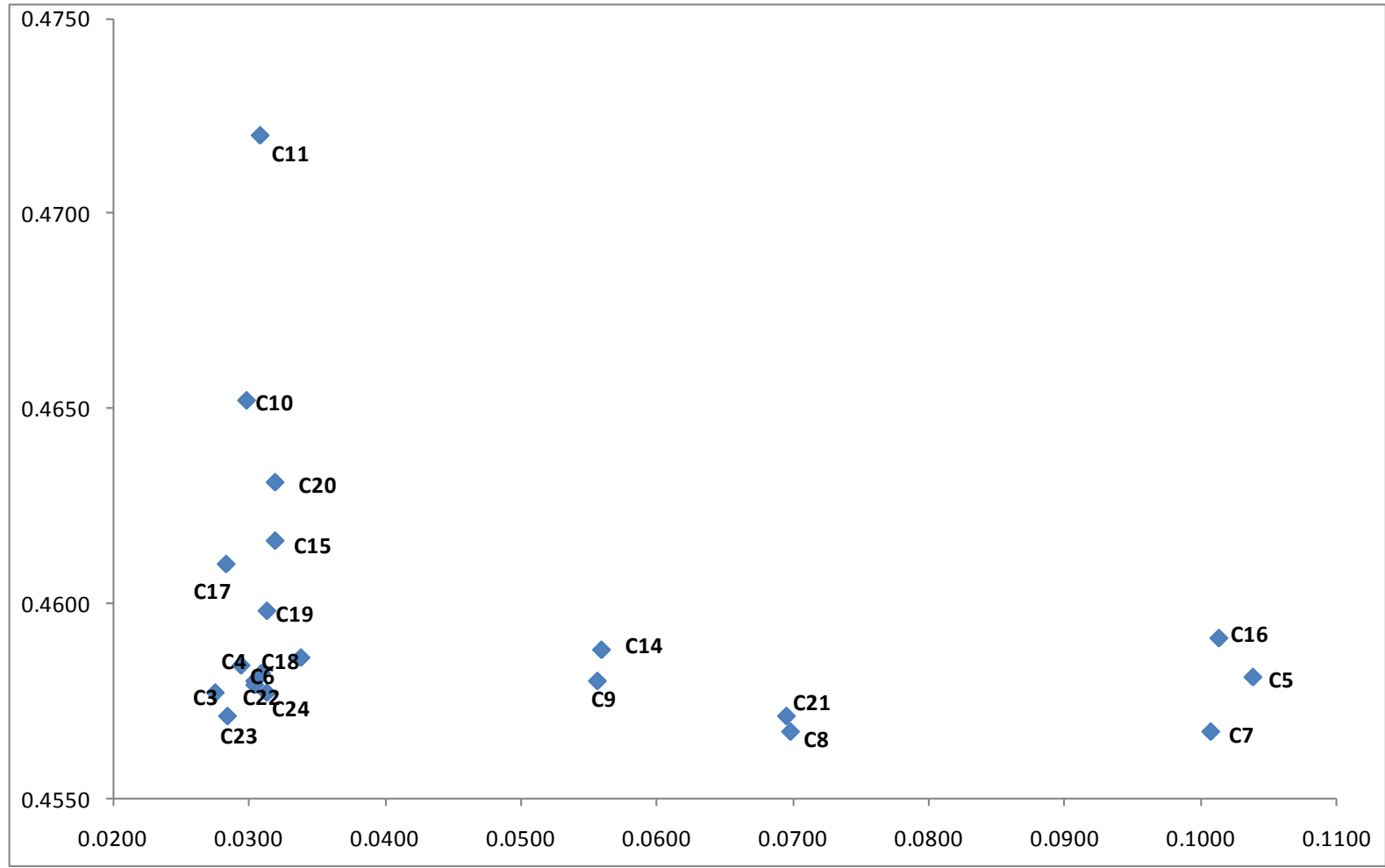

Gráfico 12 - Gráfico Markowitz: Modelo 3

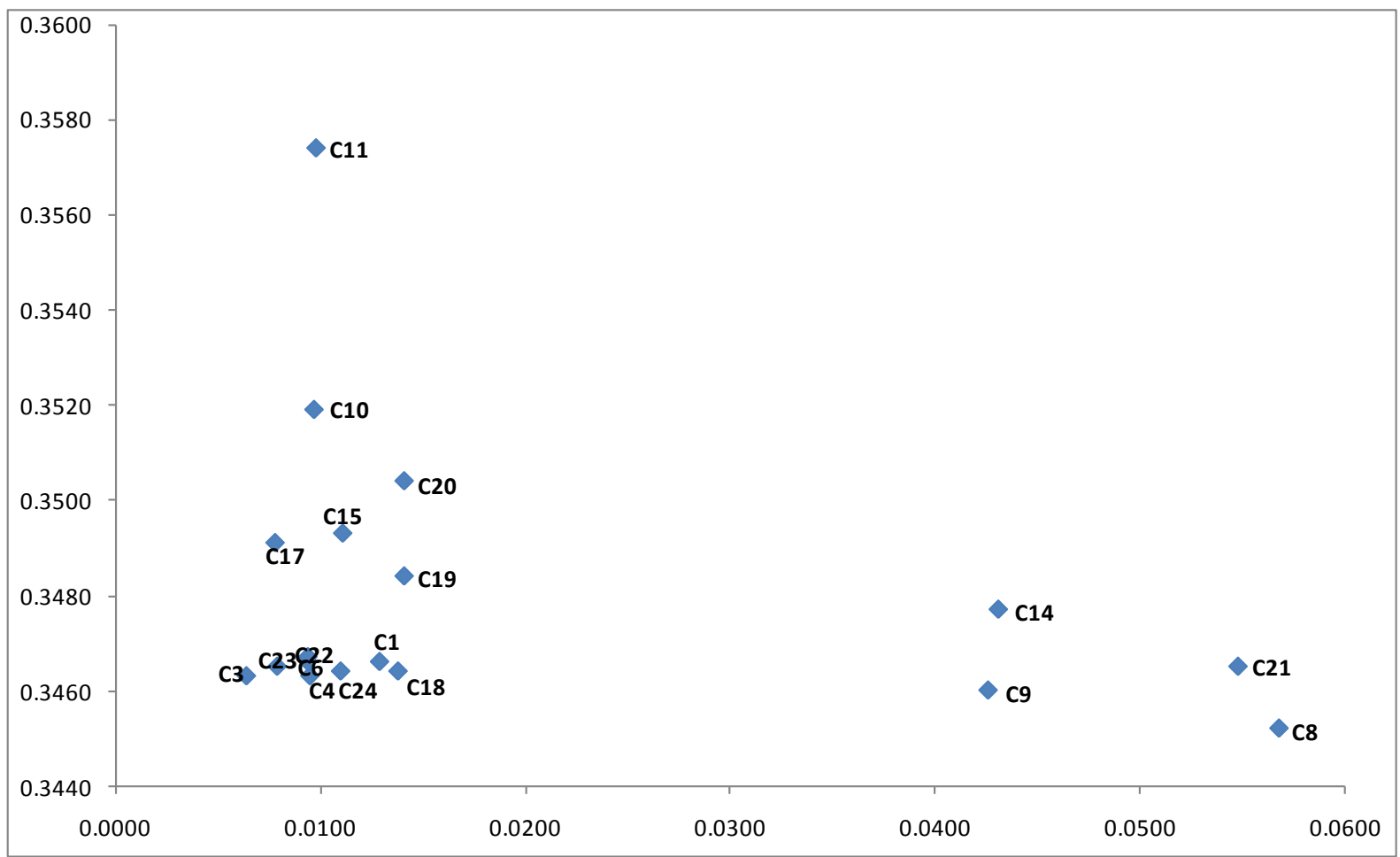

Gráfico 13 - Gráfico Markowitz: Modelo 4 